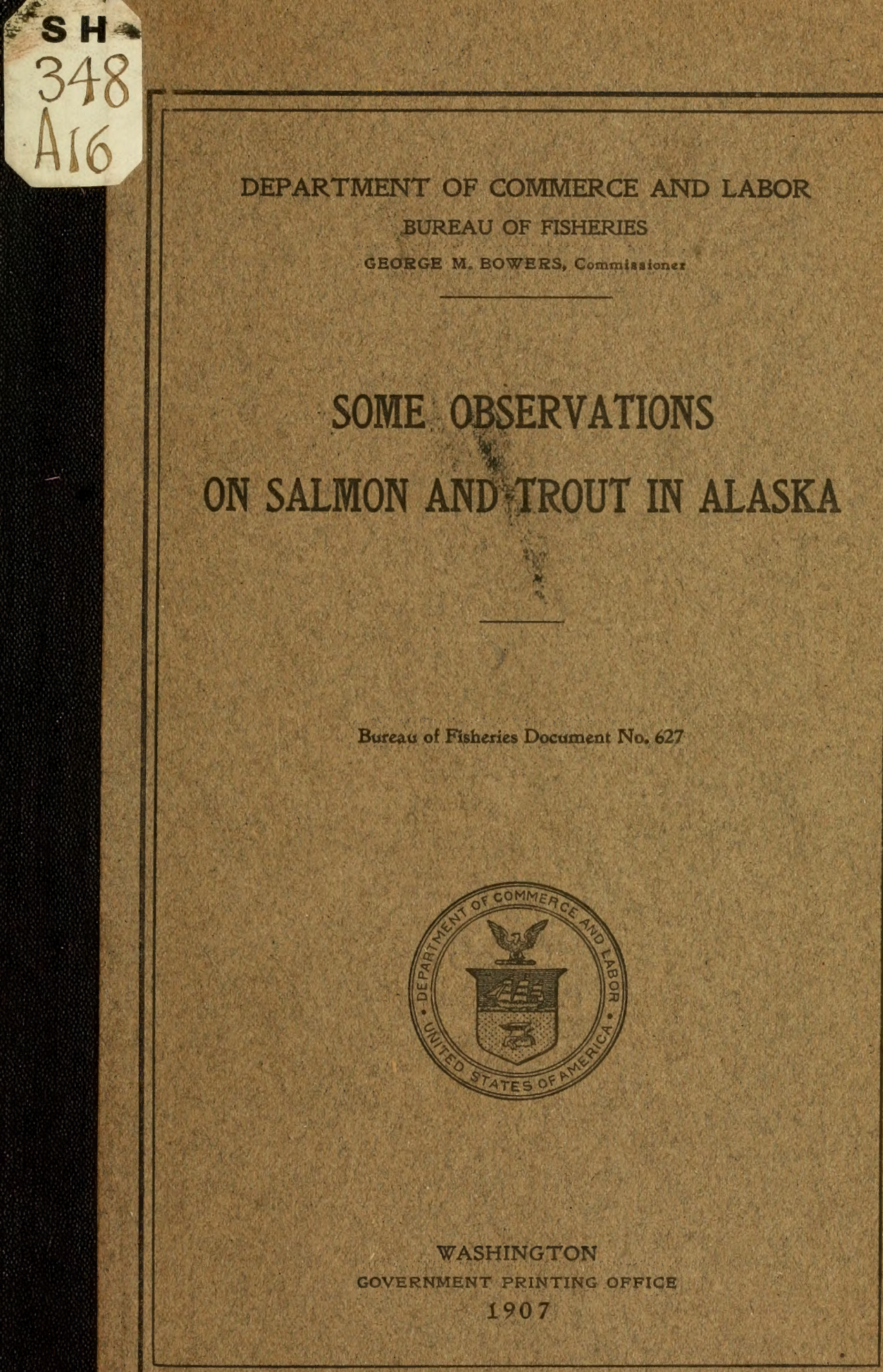






\title{
SOIME OBSERVATIONS ON SALMON AND TROUT IN ALASKA.
}

\author{
By F. M. Chamberlain, \\ Naturalist, U.S. Fisheries Steamer Albatross.
}

Bureau of Fisheries Document No. 627. 

DEPARTMENT OF COIMMERCE AND LABOR

u. S. BUREAU OF FISHERIES

GEORGE M. BOWERS, Commissioner

\section{SOIME OBSERVATIONS}

\section{ON SALIION AND TROUT IN ALASKA}

Bureau of Fisheries Document No. 627

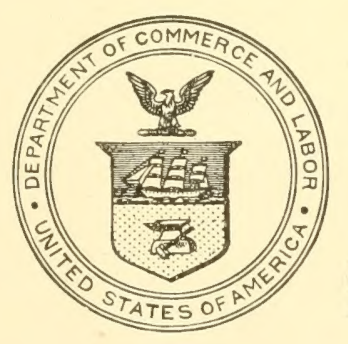

WASHINGTON

GOVERNMENT PRINTING OFFICE 1907 


$$
\begin{gathered}
S H 348 \\
\text { A } 16
\end{gathered}
$$




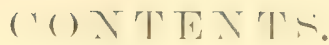

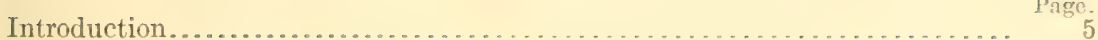

Distinctive characters of the species............................ 6

Common names.....................

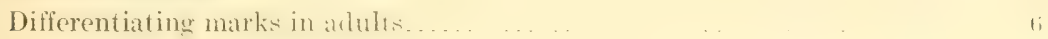

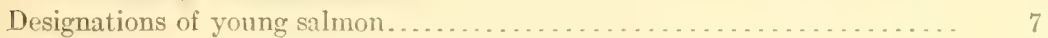

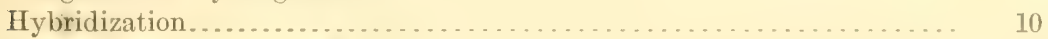

Ressemblane of the youmb............ ... ... 11

Detailed descriptions of the young......................... 13

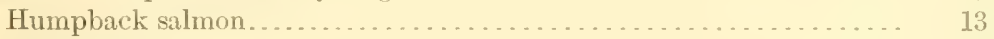

Dog salmon............................................ 14

King salmon ...................... . . 15

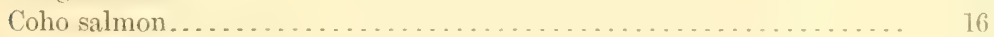

Sorkeye salmom ............

Steelhead trull ............. 19

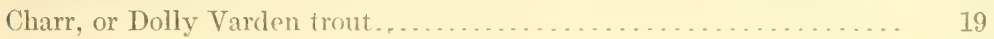

The basins studied.......................................... 20

Conditions controlling the work. ........................ 20

Method used to determine migratory movements . . . . . . . . . . . . . . 21

The Naha ........................................... 22

Character of the stream................................. 22

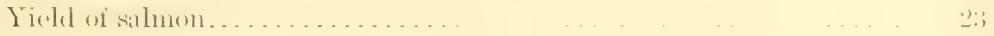

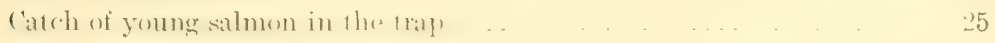

Yes Bay Stream...... . . . . . . . . . . . . . . . . . . . . . . . 27

Karluk River.................... . . . . . . . . . . . . . .

Suitability as a spawning stream......................... 28

Movements of young salmon as shown by trial watches ........... 28

Conditions reported in British Columbia ........................ 30

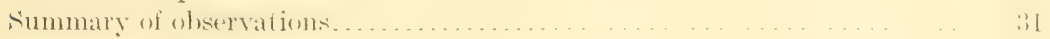

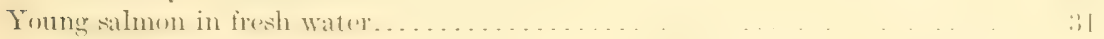

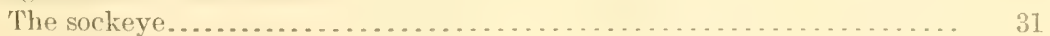

Movement of fry above the lakes.............. . . . . . . . . . . . 31

Food and feeding.................................... 32

Food supply in relation to the hatching seasom ................ 34

Growth in fresh water.................... . . . . .

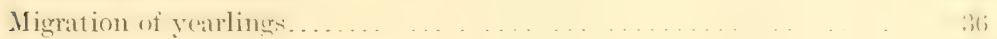

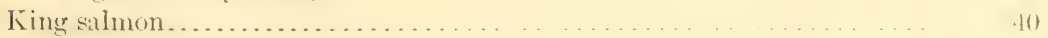

Age and season of migration .......................... (1)

Effect of change from fresh to salt water...................... 42

Food .......................... . . . . . . . $4: 3$

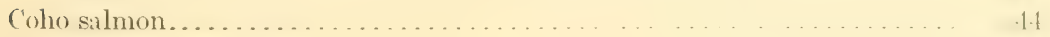

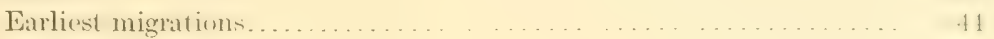

Food and habits........................................ 44 
Young salmon in fresh water-Continued.

Page.

Dor salmon .....

Humpback salmon..................................... 48

Trout and charr......................................... 48

Sea habits of young salmon.................................... 50

Notes afforded by collections and records..................... 50

The sockeye....................................... 50

King salmon........................................ 53

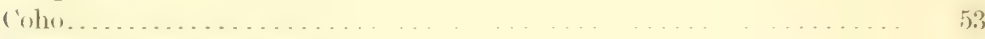

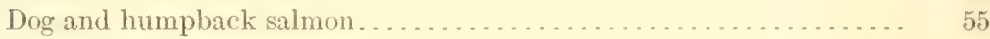

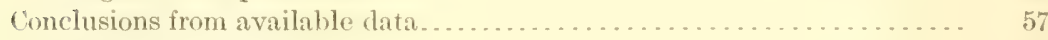

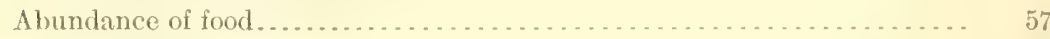

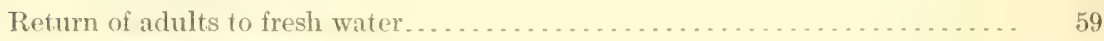

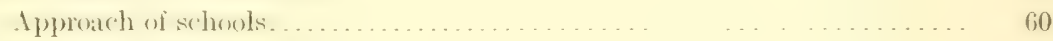

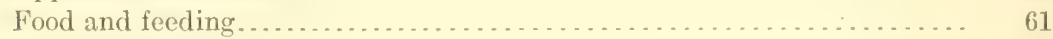

The sockeye ............................................... 61

King salmon ............................................ 64

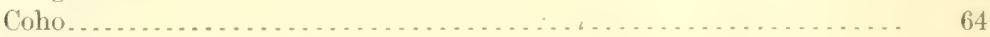

Humpback and $\operatorname{dog}$ salmon . . . . . . . . . . . . . . . . . . . . . . . 65

Relation of food supply to number of adult salmon ................. 65

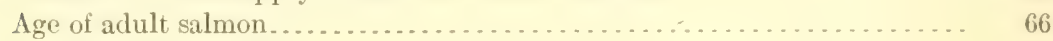

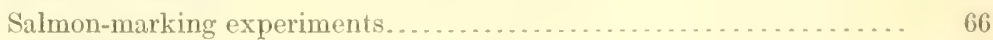

Methods.......................................... 66

Regeneration of lost parts........................... 67

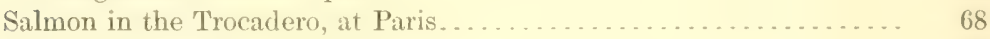

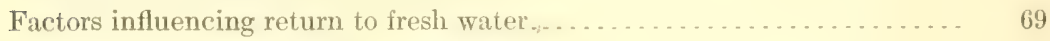

Sex instinets versus condition of nutrition ..................... 69

The different runs..................................... 70

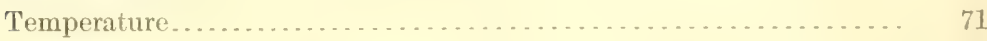

Currents............................................ 73

Ascent of streams . . . . . . . . . . . . . . . . . . . . . . . . . 74

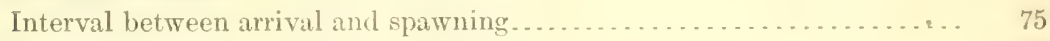

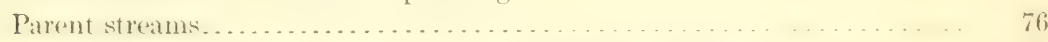

"Introduction into streams not previously frecpuented" ........... 77

"Return of marked salmon"........................... 78

"Distinctive and characteristic runs"'...................... 78

Variations in weights and measurements................ $\quad 79$

Variations in counts............................... 89

Streams not utilized by sockeyes.......................... 92

Relation of size of run to spawning area . . . . . . . . . . . . . . . . . . 93

Selection of spawning ground.............................. 94

Conditions required by the sockeye...................... 94

Preferences of the king salmon .......................... 96

Spawning streams chosen by the coho, dog, and humphrack salmon... 97

Nature of spawning beds selected......................... 98

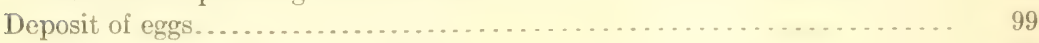

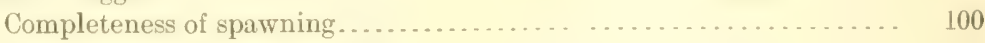

Percentage of natural production ....................... 101

Relation of spawning habits to number of fish ................ 102

Changes incident to maturation, ........................... 104

Return of adults to salt water. . . . . . . . . . . . . . . . . . . . . . . 106

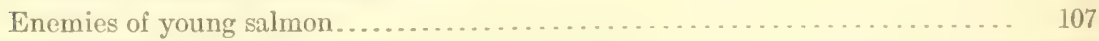

Geographical glossary .................................. 109 



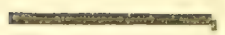

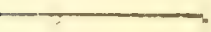




\title{
SOME OBSERVATIONS ON SALMON AND TROUT IN ALASKA.
}

\author{
By F. M. Chamberlain, \\ Naturalist, U. S. Fisheries Steamer Albatross.
}

INTRODUCTION.

To assist in the solution of various problems, it was deemed desirable in connection with the Alaska salmon investigation of 1903 to establish shore stations. The work at these stations was to comprise not only the study of the habits of the salmon in fresh waters and adjacent bays, but, in addition, a reconnaissance of all the neighboring basins with reference to availalle hatehery sites, observation of the methods employed in taking fish for the canneries, an inquiry into the sea habitat and the factors influencing the return of the adult fish, an inquiry into the efficiency of the hatcheries then operated, and a general study of the biological features of territory immediately adjacent to the stations. The facilities offered by the establishments of the Alaska Packers' Association at Loring and at Karluk determined the adoption of the Naha and Karluk rivers as localities for this work. ${ }^{a}$

The greater part of the data obtained at these shore stations is contained in unpublished reports. In the present paper are presented such of the facts as bear upon the natural history of the salmon and, with a view to the application of these results in future work, some notes on the methods used in the inquiry. Most of the material contained herein relates to young salmon, but the known facts in the life of the adult, including the spawning period, are considered, and mention is made also of the trout as associated with the salmon. A chapter differentiating and describing the species, particularly in the finger-

a The observations in the latter region were made between the early part of May and September, 1903, by the late Cloudsley Rutter, naturalist of the steamer Albatross, assisted by M. H. Spaulding, of Stanford University. At Loring the work was carried on during 1903 and 1904 in charge of the writer, assisted at different times by E. L. Goldsborough and H. D. Aller, of the Bureau of Fisheries, and H. C. Fassett, fishery expert on the steamer Albatross. During the summer of 1905 ohservations along some of the above lines were continued by the writer at Yes Bay, in connection with other work of the Albatross, with the assistance of Mr. Fassett and of J. S. Burcham, of Stanford University. 
LOWER PART NAMA BASIN based on stenometer and Compass survey E.L.Goldsborough F.M.Chamberlain

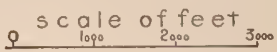

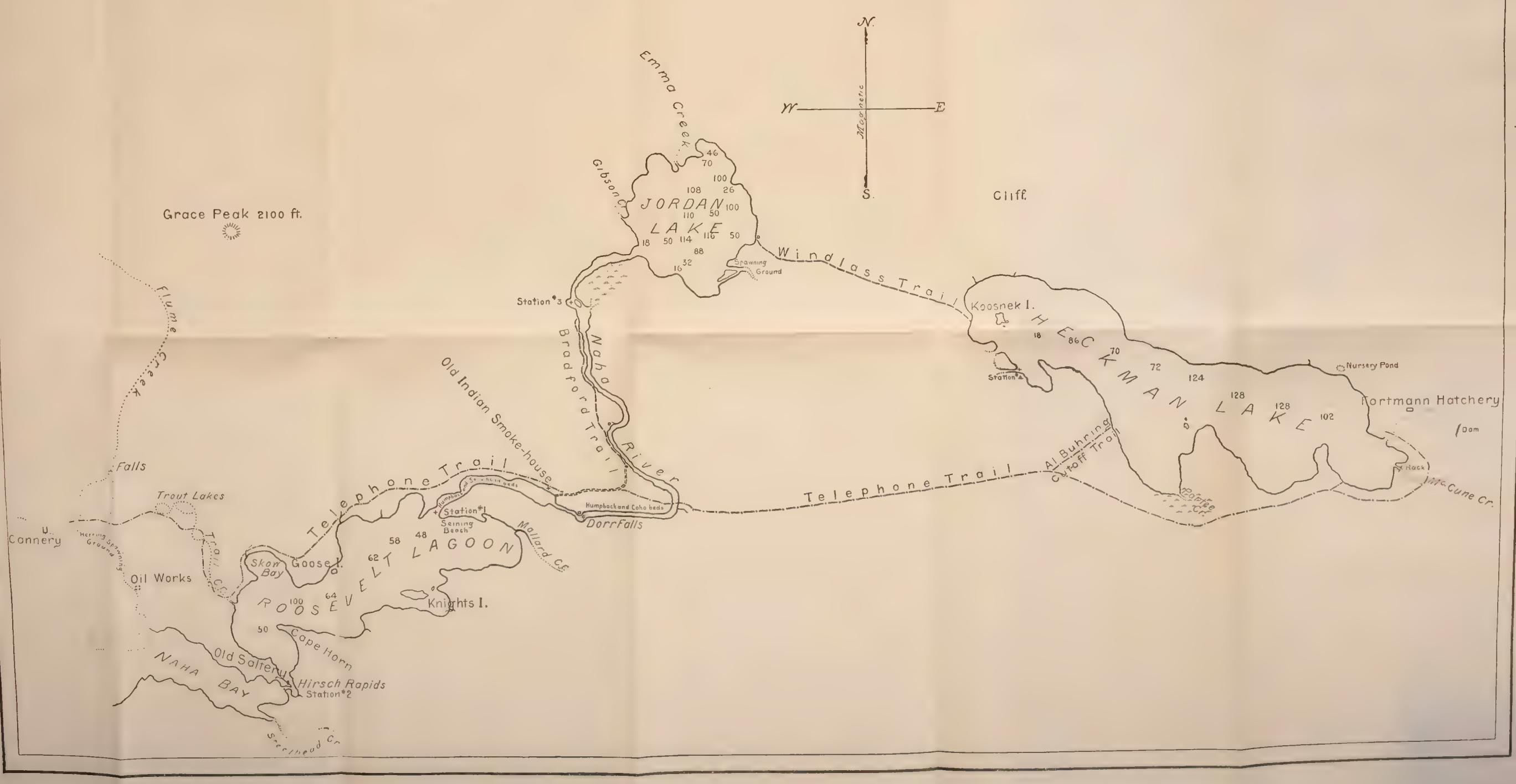



ling stage, is loblowed hy a dotaited record of the field observations on the young, and upon these data, which are largely statistical, is

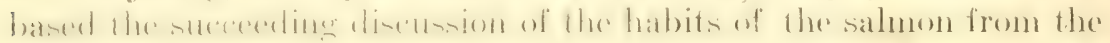
time of the migration of the young until the return of the adults to

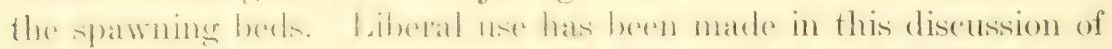
the results of provions workerson the subject, and, in addition to the (o)lections and motes mate hy the shore parties in Alaska in 1903,

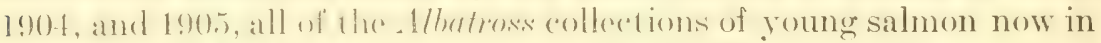
possession of the Bureau have beenstudied. The conchuling ehapters of the report ale eriven lo the disemsigno of guestions relating to the adult salmon, and eomlain in tabular form the statisties of weights and measurements of nealy io.000 sockeye salmom, with anatomical counts of about 4,600 of these. In the entire paper the sockeye, as the most valuathlo (onmmereial salnom of Mlaska, has been made the main feature.

\section{DISTINCTIVE CHARACTERS OF THE SPECIES.}

\section{COMMON NAMES.}

The most commum appollations of the various species as they are known in Alaska are used in this paper. There seems to be no reason why, for example, the words "quinnat," "chinook," and "king," which in a lowe way pertain, respectively, to the Sacramento, Columbia, and Aaskan twherytsedu, should be continued to the confusion of readers. The "blueback" of the Columbia differs in no specific escential from the "sockere" of Haskia. Names based on characters common to several species, such as "red," "silver," etc., are especially apt to be confusing. The name "trout" as here applied to small foncrelinge may include steelhead, ranbow, and cuthroat. Indivilual vartations in both trout and salmon overlap the limiting points in most characiels, hut in the salmen the sum of various char-

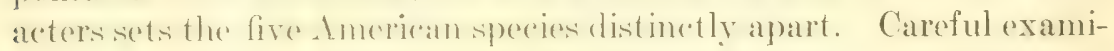
nation has so far failed to show any distinguishing character to diflerentiate the young of these trouts. Indered, alpyarently no specific difference is constant in the adult.

\section{DIFFERENTIATING MARKS IN ADULTS.}

Fishermen and latere handlers of salnon roughly but rery aceu-

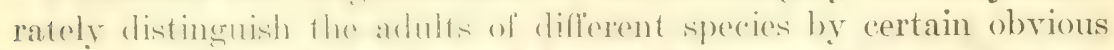
charieters. The kiner salmon is known by the small black spots on the tail. The tail of the humpladek is spotted, hut with larger oblong spots. The batek of holh kiner and ("oho are eommonly spotted, the spots of the reho hering as a mole smaller than those of the linge but these spots are mol moted hy lishement. Rarely the sockeye shows a few spets. particulaty on the tail, hat these are never distinet as in the other species. To, the seatrom form only does this statement 
apply; the dwarf lake-rlweller is spotted.) The steelhead, also a spotted fish, is at once recognized by its slimness, the square tail fin, and the deep catudal peduncle. It is difficult to pick up a steelhearl by erasping the tail, whereas a salmon may be readily so held. Salmon without spots-sockeye, dog salmon, and sometimes the cohoare somewhat confusing. The sockeve is usually distinguishable by the blue back after death, the sharp nose, and the narrow maxillary, while the tail fin lacks the produced pointed lobes of the dog salmon; also the scales are firmer and show a clean-cut paring, and the flesh is intensely red. The coho and dog salmon scales when silvery appear to be of a finer and more delicate texture than those of the sockeye. This is especially notalle in the dog salmon. The female dog salmon is usually very deep, both dorsoventrally and in lateral thickness"plumpness." The caudal peduncle is less compressed than in other species and the curves joining it to the body are shorter than in the coho. In the Alaska fisheries the dog-salmon males are seldom taken until the secondary sex characters begin to be developed-the "hookbill" and dirty coloration." The produced caudal rays mentioned above and the light eolor of the flesh are distinguishing marks in this species. The coho is distinguished from the dog by less delicate seales and deeper peduncle, by its small pupil, and in general by the occurrence of spots often at first overlooked.

In closer examination one will consider the greater length and fineness of the gillrakers in the sockere, the increased number of anal and branchiostegal rays in the king, the fine seales of the humpback, the large and few pyloric ceca of the coho. The dog salmon possesses no single diagnostic mark, but differs from the other species respectively in each character as mentioned above. Changes incidental to the spawning period will be noted under that head.

\section{DESIGNATIONS OF YOUNG SALMON;}

The lack of a distinctive terminology for the young of fishes has led to much confusion in the interpretation of reports of fish culturists and investigators, more or less consequent acrimonious debate, and some legal entanglements. In an effort to settle this matter for the benefit of American writers and readers, the American Fisheries Society in 1905 adopted the following nomenclature: ${ }^{b}$

Fry $=$ fish up to the time the yolk sac is absorbed and feeding begins.

Advanced fry $=$ fish from the end of the fry period until they have reached a length of 1 inch.

Fingerlings $=$ fish between the length of 1 inch and the yearling stage, the various sizes to be designated as follows: No. 1, a fish 1 inch in length and up to 2 inches;

a "In handling a large number of dog salmon in 1907 it was observed at Juneau early in September that many gren silvery males were being taken in the traps at Shelter Island and vicinity. Among these were several dog-salmon grilse." (Fassett.)

$b$ Report of the commiswiner of Fisheries for fiseal year ended June 30, 1906, p. 24. 
no. 2, a fish 2 inches in length and up to 3 inches; no. 3 , a fish 3 inches in length and up to 4 inches, ete.

Toarlings-lish that are 1 year old, but less than 2 years old from the date of hatching. These may be designated no. 1 , no. 2 , no. 3 , etc., after the plan described for fingerlings.

These definitions have been generally adopted in government and state reports and are the ones used in this paper. The use of the French term "alevin" instead of "fry" for the larval stage of salmonids has been abandoned here for the reason that the French writers do not restrict the term to that period of development of the young fish. Though the use of "alevin" has had the support of such authorities as Francis Day $y^{a}$, Livingston Stone ${ }^{b}$, and Cloudsley Rutterc, it seems umnecessary, if not even absurd, to continue the use of a foreign word and give it a meaning not recognized in the language from which it is drawn, more especially as even the writers mentioned above did not make a strict application of the term.

Some French writers " have apparently endeavored to make a technical use of the terms "alevin" and "fretin," but their example has not been followed by later writers, and the word alevin seems to be used now to designate the young of the salmon in the most general way.e In the same manner the German word "Brut," or "Jungbrut," has about the same latitude as has been given hitherto to the word "fry" in English, nor does the German term "Setzlinge" admit of strict application. ${ }^{f}$

The words "larva" and "larval" have been used by many writers in descriptions of the young salmonids. Other's would restrict these terms to fishes exhibiting a greater change in the stages, such as the eels and the ladrfish. Is in neither case is there a complete metamorphosis, this limitation is scarcely tenable. 'The terms, however, are not yet current among fish culturists.

The great diversity of size among species and among individuals of a given species at the time of hatching, as well as the intimate dependence of fish growth upon environment, in some eases may

$a$ Francis Day, British and Irish Salmonidæ, p. 43, 44, and 82, 1887.

$b$ Livingston Stone, Domesticated trout, p. 151, 6th ed., 1901.

$c$ Cloudsley Rutter, Natural history of the quinnat salmon, Bulletin U. S. Fish Commission, vol. xxII, 1902, p. 69 and 72.

a Larbalétrier, Albert, Traité-Manuel de Pisciculture d'eau douce, p. 220, 1886: "Alevins.-Les jeunes poissons venant d'éclore portent le nom d'alevins. Toutefois, il est à remarquer que cefte dénomination s'applique surtout aux jeunes des saumons, truites et ombres-chevalier, tant qu'ils n'ont pas résorbé la vésicule; après, ils constituent le fretin; prur les carpes et autres cyprins, quelques auteurs préfèrent l'appellation de feuilles. Cette distinction ne nous semble pas nécessaire; d'ailleurs, nous ne sommes pas seul à penser de la sorte, car le nom d'alevin tend à se généraliser."

$e$ C. Raveret-Wattel, La Pisciculture, vol. II, 1907, p. 185.

f Paul Vogel, Ausïürlichess Lehrbuch der Teichwirthschaft, p. 334, 341, 347, 349, 1898. 
seem to introduce inconsistency into the definitions adopted. Thus under some circumstances a yearling char might be found of less size than a salmon fry; but it is believed that hy use of the above nomenclature an exact interpretation of languages will always be made possible. As in all instances involving individual characters, physiological and physical limits may overlap. Salmon fry usually begin to feed before the complete absorption of the yolk, a remmant of the rolk being persistent even for some time after the ventral walls have united and all outward appearance of the sac has been lost; and hence the migrating young of the salmon could with equal propriety be termed fry, since many still have yolk remmants, or fingerlings, since they have begrum to a small decree to feed and have become over an inch in length. In this paper, in all cases where the schools contain many individuals with the embrenic fin membrane still evident, the term "fry" is retained. In case of the humplarek and doer salmon young which were taken in salt water, it is sometimes impossible to know whether "fingerling" or "yearlines" is the proper designation, but since it seems probable that the creater number were less than one rear of age, the term "fingerling" is nsed. In the case of the coho the distinction is eren more doultful, but is applied with as much discrimination as the state of our knowledge permits.

The terms "parr" and "grilse" have come into American use from the British writers on Salmonidae, but the latter clesionation has attained a meaning somewhat different from the original.

"Grilse," as applied to the Dtantic salmon (Salmo salar) by both American and British writers, refers to the incompletely grown fish which return from the sea to the rivers to spawn. Tnlike the Pacifie salmon (Oncorthynchus), the Alantic salmon, both male and female, mature perfect sex products before completing their growth, and after spawning in the same manner as the erown fish of one or more years' greater age, return to the sea as "crrilse-kelts" to cont inue their growth and return the following season (or second vear after) as "salmon." What are known as "grilse" amone Pacific salmon are the small males, presumably lacking at least one year of the usual age of adults of the species, which leave the sea for the spawning heds, mature perfect milt, but after "spawnine" die in the same manner as fully grown males. Females in no instance show this precocity. While there are sometimes small females among mature fish, they grade into the regular size in such manner that they can only be supposed to be those individuals which by heredity or unfarorable environment have failed by a greater or less degree to reach the standard size. (See p. 86-87.)

The term "parr" is applied in general to young fish still in fresh water and showing the dark hars or parr marks. They may be fingerlings, or yearlings, or even adults. The males of this stage in the 
case of the Pacific salmon in some instances mature perfect spermatozoa, but whether they spawn and die immediately afterwards is not known, nor is it known definitely whether fingerling parre may develop the sex product.

The terms "smolt" (frequently still spelled and pronounced "smelt") and "kelt" as used for stages of the Atlantic salmon hardly have parallels in the case of the Pacifie salmon. If any of the genus Oncorhynchus return to sea as kelts, it has not yet been fully demonstrated, and ahmost the entire weight of evidence is against the belief that it "ver oceurs. The term "smolt" (French "tacon") is applied, in contradistinction to parr, to that stage of Satrro salar when, in fresh water, the parr marks are lost and the young fish assumes its livery of silver in preparation for its descent to the sea. ${ }^{a}$ It might be used with some propriety of the yearling migrating sockeye, but it seems undesirable to confuse further the meaning of words which have their proper use only with the eastern species.

\section{HYBRIDIZATION.}

The question of natural hybridization has never been investigated, though it has long been well known that trout may be artificially crossed and fertile hybrids produced." That the species of salmon may be variously crossed with suecess has also been demonstrated, but owing to the difficulty of retaining them in fresh water until of breeding age the fertility of salmon hybrids has not been proved. Rarely adult salmon are taken which seem to possess characters of two species, but on the basis of predominating characters they have been assigned to one or the other of the species and the possibility of a hybrid ignored. The differences in time and place selected by the different species of salmon for spawning minimizes the possibility of natural hybridization; and the deficient vitality of crossed exgs and hybrid fry is, perhaps, sufficient to account for the failure of most if not all such accidental product when natural vicissitudes must be overeome. Moreover, the young of the different species of salmon are distinct and show characteristically distinct habits. This is not so evident, however, in Alaskan trout. Rainbows and st eelheads spawn together in the Naha. Spawning cutthroats have not been noted there because they do not happen to inhahit that portion of the Naha which was under observation; but their serrecration is inconstant. One species or the other may he most numerous in the lower or upper reaches of a stream. In the Naha basin cutthroats are more numerous

a Day, op. cit., p. 90.

$b$ For a full discussion of hybridization of trout, see "British and Irish Salmonidæ" by Francis Day, p. 47-50, 254-270, pl. $x$ and $x \mathbf{I}, 1887$, and Paul Vogel, op. cit., p. $308,311$. 
in the upper sections of the system; at Yes Bay the case is reversed. If the fry and fingerlings of the three recognized species possess any distinctive marks or habits these have so far escaped detection.

\section{RESEMBLANCE OF THE YOUNG.}

By one who knows the adult salmon, the young of the salmon are not apt to be confused with any fishes except trout. Of the fishes having an adipose dorsal they are readily distinguishable from the capelin, smelt, and eulachon by the siphon-shaped stomach and numerous cœcal appendages; the grayling is known by its high dorsal fin; the whitefish by its comparatively small mouth.

The young of the true trout very greatly resemble the spotted species of salmon, and are distinguishable mainly by the short anal fin. The salmons usually show at least 14 fully developedthat is, full length-rays, exclusive of the :3 to 5 short, simple (unbranched) rays in the front of the fin. Sometimes there are but 13, and in rare instances only 12, while the number may be increased to 17 in the sockeye, which normally has 14 , and in the king salmon, with 16 as a normal, the extreme will doubtless be still greater. The trout have normally 10 to 12 developed rays in the anal, but while this seems little separated from the number given for the salmon, as a rule the extra length of the fin in the latter may be noted by even a casual comparison. When spread the fin of the trout fingerling shows a rounded outline, the front rays somewhat more evenly graduated than in the salmon and the hinder rays much higher in proportion, causing it to resemble the dorsal in general outline. The anal of the sahnon fingerling usually has a slightly concave outer margin, the hinder rays being shortened. The charr (Dolly Tarden, or "salmon trout"), in addition to the characters of the anal as just described for the true trout, is distinguishable by the peculiarly mottled coloration, and in the advanced stages also by the less compressed body.

The different species of salmon (Oncorhynchus) are not usually difficult to distinguish from one another, ret individual variations sometimes confuse the determination. While in adults the sum of various differentiating characters makes it possible to decide the species, the late development of some characters greatly increases the problem in immature examples. It is possible that some local variations obtain; for example, sockeye fingerlings from Wood River seem to have a much smaller eye than fingerlings of the same size and species in Southeast Daska. There is also much variation in the length and number of eillrakers in the young of this species and perhaps also in those of the humplack salmon. From the number of specimens at present arailable for sturly it can not be determined whether or not this variation is of geographical origin. 
The humplanek (1). gorbuscher) is unique anonge the salmons in never dereloping the parr marks. It is usually entirely silvery in all the young stages, and is the only one of the salmons whose roung up to some 6 inches in length, taken in fresh water, will show no parr marks even under the scales. Ar possible exceptions to this must be noted the dwarf sockeye, whose young are as yet unknown, and perhaps small mature fishes returning for spawning.

The fingerlings of the dog salmon ((). licta) have the parr marks sometimes much reduced, and those readily disappear in poorly preserved specimens. But where sereral examples are at hamd the greater average size in the rounger stages, the slightly lifferent outline, and the presence of these marlss will always distinguish them from the humpback.

Of the four species of strongly marked fingerlings the steelhead (Salmo gairdneri) may be recognized by its short anal, as noted above for trout, and by its small size taken at the season of migration. The sockeye (O. nerlio), king (O). tschauytscha), and coho (O). kisutch), being all for some time resident in fresh water and hence very variable in size, require close inspection for trustworthy identification. In general, in the fingerlings stage the sockeye will be recognized by its more slender and tapering form, and by the more nearly circular - outline of the parr marks, thomgh this latter does not always hold true. The coho is usually distinguishable by the orange tints of the lower fins (a character rarely absent) and by the white front margins of both anal and dorsal, but especially by the falcation of the anal through the extreme production or elemgation of the first developed rays. The king, very similar to the coho in eneneral outline, does not exhibit this extreme form of the anal, and in the specimens examined from the Farluk River the parr marks are larerer and the marking of the back much more notable. In a careful examination the sockeye can almost always be identified by the greater length and number of the gillrakers, and the king by the greater number of branchiostegal and anal fin rays. (See detailed descriptions following.)

In salt water the parr marks are rapidly covered by the brilliancy of the silver, so that, except the king and coho, which are spotted, all the species soon become plain. It is not known when the spots of the arlult humploack lirst appear. Whether this obliteration of the parr marks by the silver orereast is caused by the salt water may be questioned, although in the trout, which are known to run indifferently in salt and fresh water. the change is marked, fish from salt water being much more silvery. I have taken one example of sorekere rearling in ordan lake that seems almost as silvery as the salt-water individuals of the same size, but it is entirely unlikely that it had returned from the sea. ${ }^{a}$

« See under smolt, p. 10. Day, op. cit., p. 90. 
Another change with residence in the sea is a rapid increase in proportional depth. This is most marked in the coho. Seven examples from the head of Naha Bay, Nay 31, length 98 to $117 \mathrm{~mm}$., had depth 4.6 to 5, while in four examples taken August 2, at the cannery wharf, 154 to $210 \mathrm{~mm}$. length, the depth is 3.75 to 4.4 , which approaches the normal depth of the adult fish with matured sex products (3.5 to $4+)$.

\section{DETAILED DESCRIPTIONS OF THE YOUNG.}

The following key will assist in the identification of small fingerlings. In larger examples-as large fingerlings and yearlings-the specific characters of the adult must be the main reliance.

Key for Inentification of Young Salmon and Trout Between 1 and 2 Inches in Lengtit.

With adipose fin, large mouth, moderate dorsal fin, siphon-shaped stomach.

a. Anal fin long, at least 12 developed rays, the last of these much shorter than the first, giving the fin a straight or concave margin or outline......... SALMoN.

b. Showing no distinct parr marks. Back dark in dead examples.... gorbuscha.

bb. Usually with distinct parr marks.

c. Parr marks less distinct, mainly above lateral line, body comparatively slender; gillrakers short, equal to less than 2 interspaces; eye small.

keta.

ce. Parr marks more distinct, showing below lateral line; body rather slender or deep; eye large.

d. Gillrakers long, equal to or greater than 2 interspaces; body rather slender; parr marks tending to become circular........... nerka.

dd. Gillrakers short; body deep; parr marks well defined bars.

e. Parr marks narrower than interspaces, often orange coloration on fins; branchiostegals and anal rays few, 13 or 14; anal with marginal stripes......................... kisutch.

ee. Parr marks wider than interspaces; branchiostegals and anal rays many, 15 to 16 , anal not striped...........tschawytscha.

aa. Anal fin short, fewer than 12 developed rays, the last not much shorter than the first, the entire fin thus having a convex outline or margin, the height great in proportion to length of base................. Trout and Crinr.

b. Parr marks as bars, body compressed, depth carried well toward tail. . Trout.

bb. Parr marks as roundish blotches with mottling above and below, body less compressed, tapering rapidly toward tail.................... CHARR.

The Humpback Salmon, Oncorhynchus gorbuscha (Walbaum).

The humpback fry (pl. I, fig. 3) at the time of closure of the ventral walls average about 35 to $36 \mathrm{~mm}$. in total length. Depth, greatest just behind pectorals, 6 in length (exclusive of caudal rays); in ill-nourished examples the slendernest beemes marked, this usually quite notable in late migrants; head about 3.5; eye 2.5 in head; nose round and blunt, tip of lower jaw scarcely reaching profile; contour in front of dorsal fin little arched; lunation of caudal slight; pectoral rounded, 2 or a little more in head (measured from axil to tip of longest ray); longest ray of dorsal about 2.5 to 3 ; longest ray of anal 3 to 3.75 ; greatest length of ventral equal to or somewhat greater than greatest height of anal; gillrakers long and close-set, about $5-1.3$ developed, Iongest equal to half diameter of pupil, and to the distance from first to burth (3 interspaces) at upper end of lower limb. 
In life, back green to bronzy. changing to indigo blue upon death; the sides silvery with brassy luster and green tints; ventral surface silvery white, usually without marks of any kind, but rarely with a few faint short parr marks above the lateral line; a narrow median dark line on back; membranes of caudal greenish, with black punctulations; dorsal similar with a narrow darker front margin; pectorals and lower fins colorless; iris greenish silver.

In preserved specimens, particularly formalin specimens, a magnifier shows minute punctulations over almost the entire side, the back, and the dorsal and caudal membranes, and sometimes on the maxillary, chin, and throat.

The humpback fingerling (pl. II, fig. 2) is little changed from the fry described, except in size. It is the most slender species of the genus, with head long and pointed. In 20 examples from Karluk Beach 65 to $92 \mathrm{~mm}$. in total length, the average depth was 5.57 in length to base of middle caudal rays, extremes 5.12 to 6 ; in 6 examples 83 to $92 \mathrm{~mm}$. long the depth was 5.54 , head 4.4 , eye 3.8 in head, pectoral a little less than 2, dorsal 2.26, anal a little more than 3, ventral 2.46. Branchiostegals 11-12 to 12-13; gillrakers 10 to 13 upper limb and 16 to 19 in lower limb, longest from $1 \frac{1}{3}$ to $1 \frac{1}{2}$ times diameter of pupil and spanning 4 to 5 interspaces. The length and number of the gillrakers is not infrequently greater than in the sockeye fingerling, but the absence of visible scales in the smaller individuals, and their delicacy and small size in the larger of the humpbacks, as well as the more slender body outline, will distinguish these fingerlings from the sockeye. In the adult humploack the gillrakers are 11-17 to $13-19$, the longest $1_{3}^{2}$ to 2 times diameter of pupil, covering 4 interspaces.

Colors of the fingerling: The dusky of the dorsal shows as a diffuse blotch on the front and distal portions, the dusky of caudal more intense toward the points of the lobes and at the base, but less marked than in the dog salmon; a little dusky appears in the axil of pectoral. A few small black blotches on the upper side were noted in a few of some fingerlings reared at the Clackamas station.

At this stage the scales, though very thin and delicate, may be made out with a magnifier or a good eye. The lateral line is a mere furrow and shows no tubing. In the dog salmon of the same or much less size the scales are evident and tubes of the lateral line distinct.

In the Karluk specimens examined the ovaries are ribbon-like, whereas in other species the ovaries are more cylindrical and usually somewhat swelled at the anterior end.

The Dog Sammon, Oncorhynchus keta (Walbaum).

The dog-salmon fry (pl. I, fig. 5) attains a length of about $40 \mathrm{~mm}$. by the time the ventral walls are fully united, perhaps a greater length than the fry of any other salmon of the genus. It resembles the humpback in general shape. Greatest depth just behind pectorals, 5.5 to 6 in body; head 4; eye about 2.66 in head; pectoral 1.75 to 2; dorsal about 2 ; anal about 2.5 ; ventral equal to anal; gillrakers little more than tubercles, about 5-11 to 12 may be made out, longest about one-fourth diameter of pupil, equal to about one interspace.

In life, ground color bright grass green, becoming slightly darker on hack and paling on lower side to an overcast on the silver; occasionally a brassy luster on back; lower parts silvery with the palest green iridescence; back with very fine black punctulations, fusing into numerous small blark spots about the size of pupil irom nape to lase of caudal; a median dark line on back in front of dorsal, not marked back of dorsal. The punctulations cover sides to axil of pectoral in front, to about halfway between lateral line and ventrals, and surround caudal peduncle, becoming coarse and scattered below. The parr marks, from 6 to 12 in number, lie mainly above lateral line. 
Pectoral and lower fins uncolored, caudal and dorsal greenish, fading distally, black punctulations on membranes, dorsal with blackish front margin. Iris brassy.

In preserved specimens the general color is silvery, with the dusky shades as described for the humpback, but never so dark on the back. Parr marks along lateral line elliptical or oval in shape, narrower and longer (deeper) toward the head: greatest diameter equal to eye, usually more numerous and narrower than in the sockeye, and not becoming bars as in the coho and king; also more subdued by the silver overcast than in the two last-mentioned specis:s; along median dorsal line a row of small blotches sometimes coalescent into a mere stripe, the area between this and the parr marks usually spotted with round dots less than half diameter of pupil: oceasionally a few broken blotches below. Dorsal and caudal membranes and first ray of pectoral dusky; other fins immaculate.

The dog-salmon fingerling (pl. Ir, fig. 3) is less slender in outline than the humplack, which, except that the dog salmon is obviously scaled, it otherwise resembles.

In 26 examples from Whidby Island, taken June $30,190: 3,78$ to $122 \mathrm{~mm}$. total length, sexes in equal numbers, the average depth is 5.1 in body $(4.87-5.4)$; head 4.4 ; eye 3.3 in head; pectoral 2-; dorsal 2+; anal 3; ventral 2.4; dereloped anal rays 13 and 14 ; branchiostegals $13-13$ to $14-15$; willrakers $8-12$ to (1)-15. longest about equal to pupil, spanning about 3 interspaces (sometimes only 2): s(ales 130161.16 , average 13!). In

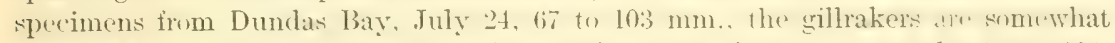
shorter, 5 to once the diameter of pupil, cevering 2 to :3! interspaces; scale: 12916136 , average 132 .

In fingerlings from Naha Bay, July 2, 50 to $65 \mathrm{~mm}$. in length, the parr marks are still apparent. In sea-run examples from Karluk Beach, July 24, up to $100 \mathrm{~mm}$, they scarcely show through the seales, but are quite evillent when the scales are stripped. The other coloration much as in the late fry stage; chin dusky; several rays of the pectoral with punctulations; tip of dorsal, except last ray, distinctly black; tip of caudal black, marked even in fork, this black tip of caudal distinguishing them roughly from the humpback of the same size, though the sealiner must be the final test.

The King Salmon, Oncorhynchus tschawytscha (Walbaum).

The young king salmon (pl. I, fig. 4, figure and description from Karluk River specimens) at the time of the complete union of the ventral walls are from 35 to $37 \mathrm{~mm}$. average length. In general outline they are less slemise and tapering than the humploack or dog salmon. The depth, greatest in the region of front of dorsal, 4.25 in body; head about 3.33 to 3.5 ; eye 2.5 in head; pectoral 1.75 , vertical fins high, dorsal 1.5 ; anal 2 ; ventrals 2.33; gillirakers about $4-11$, short and well separated, longest equal to one-half diameter of pupil, spanning 1 interspace. The increased number of branchiostegal and anal fin rays (about 16 in each) help to distinguish this species.

Ground color of specimens in alcohol silvery, and except breast and in front of ventrals, with fine punctulations; about 9 to 12 long narrow parr marlis usually equal to or greater in width than the silvery interspaces and lying about equally on either side of lateral line; a dark median dorsal line in front of dorsal fin, not so evident in caudal region; between this and the parr marks numerous round or oval blotches about size of pupil, the larger of these alternating with the parr marks so that it gives the upper end of these the appearance of being symmetrically margined by the silvery of the ground color; caudal lunation comparatively deep. In the Sacramento the caudal sometimes has a reddish tinge, and shades of yellow may appear on the ventrals and anal.

Yearlings (pl. II) from Karluk Lagoon, about $137 \mathrm{~mm}$. long, have the following measurements: Depth 4.4; head 4; eye 3.5-4; pectoral 1.6-1.7; dorsal 1.8-2; anal 2.3-3; ventral 2.2-2.3; greatest depth about midway between pectoral and dorsal, gracefully tapered to tip of the rather sharp nose. Gillrakers 10-13; longest equal to or less than diameter of pupil, spauning about 2 interspaces. (In adults $10731-07-2$ 
from oregon the longest gillraker is about $1 \frac{2}{3}$ to 2 times diameter of puppil, covering 3 interspaces.)

Color silvery, dark above; top of head, back, and sides to lateral line more or less thickly spotted with small roundish black spots about half diameter of pupil and less; distal portion of dorsal dusky, sometimes nearly black; caudal dusky; inner side of unter rays of peetural dusky; anal and rentrals unmarked; parr marks visible. under silver. Distinguished at sight from coho by the longer anal and the usually somewhat smaller eye, but definitely by the more numerous and finer branchiostegals and greater number of pyloric cœeca.

\section{The Como Salmon, Oncorhynchus kisutch (Walbaum).}

The coho fry (pl. I, fig. 6) at the time of hatching is about $27 \mathrm{~mm}$. in total length, the sac about $10 \mathrm{~mm}$. The greater size and the peculiar shape of the yolk sac distinguish the coho from the sockeye.

These fry average about $35 \mathrm{~mm}$. total length at closure of ventral walls. The ventral membrane on either side of the ventral fins is persistent for a long period. In general shape the coho fry and small fingerlings much resemble the king salmon. Greatest depth just in front of dorsal, about 5 in body; thence diminishing toward nose; dorsal outline arched; head about 3.75 ; "ye 2.5 in hearl; pectoral 2; vertical fins high, the front rays in both soon becoming extended; dorsal about 1.75 ; anal 2 ; ventrals 2.75 ; caudal lunation shallow. Gillrakers very short, little more than tubercles. about $5-10$.

In Steelhead Creek, May 29, migrating fry had a ground color of smoky green with brassy iridescence, black punctulations everywhere except on throat and breast; these punctulations finest and most numerous on back, becoming coarser and more scattered on lower side; lower side with a red overshade or iridescence; membranes of fins with punctulations, but on pectoral and ventral these punctulations only close to body; remainder of these fins brownish orange; caudal-fin membranes orange ground, the fine black punctulations giving a dark effect, upper and lower (dorsal and ventral) margins clear brown, most pronounced on rudimentary rays, membrane between ray branches colored and dotted as between rays; membranes of dorsal with very pale orange shade deepening on rear, front with black margin equal in width to a central membrane, sometimes a narrow orange margin in front of this; anal membranes distinctly orange with punctulations as in caudal, these becoming close near margin at extremity of long rays and forming a black band about equal in width to two rays and joining membrane, tips of these rays and membranes white, giving the fin a white front margin and a black submargin equal to two or three times the width of white; adipose with orange front and top margin; dentary surface of mandible orange-brown at tip; maxilary uncolored, with scattered punctulations; iris bronzy to brassy; cheek with bronzy ground; opercular face dark; parr marks one-third to one-fourth as wide as long, increasing posteriorly in relative width (antero-posterior), and extending about equally above and below lateral line, the first partly under opereular flap, the last roundish and usually about under adipose fin, the penultimate sometimes under adipose; a narrow dark median line on back; smaller round spots on back sometimes alternate with parr marks. Tiewed from above in water, the back shows ground color bronzy, with a few scattered dark spots: narrow supraorbital stripes ending at nostril, the median dark line showing distinctly with bronze bands of about equal width on either side.

In alcohol entire surface dusky, with punctulation except on a little of breast, some of the lower surface of head, and the paired fins. Parr marks present as 8 or 9 short and narrow bars, about one-half the width of the interspaces (variable but not usually so broad as in the king), and equal in length (depth) to about half depth of body, lying about evenly divided by lateral line, becoming more nearly round toward 
the caudal; a dark blotch at hase and front of dorsal; tips of front anal rays immaculate, forming a distal white stripe along front of fin.

A fingerling $58 \mathrm{~mm}$. in length (pl. II, fig. 4) has a depth of 4 in body; head 3.5; eye 3 in head; pectoral 1.5; dorsal (longest ray) 1.33; anal 1.25; ventral 2 (some of the first dorsal and anal rays are variably produced); villrakers, 8-14, longest onr-half diameter of pupil, spanning about 2 interspaces.

Markings much as in earlier stages, but with additional markings on back. short oval or triangular blotches appear between the parr marks, and numerous small, round, dark spots become irregularly seattered over entire upper surface, including top of head. The orange tints of the fry and smaller fingerlings largely disappear at about this size, the time of the change varying greatly in different localities. In the same degree the falcation of anal and dorsal shows local and individual variation, but it is always notable. The tips of the first 4 to 6 rays of both these fins, with the outer membrane, retain the orange color or become white, to form a stripe about half the width of the pupil at the margin of the fin; this lies upon a submarginal band of black of similar width. The distinctness of these bands is variable, but in no case are they entirely absent in fingerlings of 40 to $100 \mathrm{~mm}$., or even more, when in fresh water. At a certain point the elongated rays seem to stop growth in extension while the remainder of the fin continues its normal increase in size until the permanent form has been reached, after which all the growth proceeds together. Examples of 130 to $150 \mathrm{~mm}$. show traces of the peculiarity of both growth and color, but later there is no variation from the normal shape as found also in the king.

A sea-run yearling (pl. Iv) from Karluk Beach, wune 18, 1903, 150 mm. in length, had depth 4.75; head 4; eye 3.66 in head; snout nearly equal to oye; pectoral 1.5 ; dorsal 2; anal 2.8; ventral 2; gillrakers 9-14, longest equal to diameter of pupil, spanning about 3 interspaces (in adults from $1 \frac{1}{3}$ to 2 times pupil, spamning $23_{4}^{3}$ to 4 interspaces). Life colors (Rutter) "back olive brown, thickly spotted with black; dorsal dusky, except last ray is pale. Caudal yellowish hy transmitted light, tip dusky, the? dusky portions greater on lobes; pectoral yellowish; parr marks distinct; iris somewhat golden.' In alcohol 11 parr marks quite distinct, a little broader than interspaces and depth about half depth of body, spots on back round, the largest about $\frac{1}{3}$ diameter of pupil, covering top of head and back as far as lateral line-extending on to upper edge of caudal; anal and pectorals with very few punctulations, lower parts silvery.

\section{The Sockeye, Oncorhynchus nerka (Walbaum).}

The sockeye fry at time of hatching measures some $24 \mathrm{~mm}$. in total length, the sac itself about $9 \mathrm{~mm}$, varying in individuals. The yolk sac is approximately cylindrical in general outline, sometimes slightly deeper (dorso-ventrally) at the posterior end. It has little tendency to become pointed at the posterior ventral extremity, as in the coho.

The ventral walls become complecly united and the yolk disappears externally when the young sockeye measures about $32 \mathrm{~mm}$. in total length. At this stage both dorsal and ventral outlines are arched (the dorsal the more in alcoholic specimens by reason of the contraction of the softer ventral tissues). The greatest depth is near the middle of the body just in front of the dorsal, about 4.75 to 5.5 in length to base of caudal rays (end of scaling). In poorly nourished examples the depth is greatly decreased in proportion to the length. Head about 3.75 ; nose rounded, blunt, length about equaling half diameter of eye; eye about 2.5 in head; pectoral and dorsal about 2 ; anal and ventral about 2.66 in head; gillrakers 5 - 14 , in length about two-fifths diameter of pupil, spanning 2 to 3 interspaces.

General color silvery, becoming dusky above. There is less tendency to metallic iridescence than in the coho, and the fins do not show the orange tints of the latter. 
The ventral surface is immaculate, including all the lower fins. The fine punctulations with which the upper parts are shaded extend from just behind the gill-openings to slightly below the lateral line and posteriorly approach more and more the ventral surface until, at the caudal peduncle, they reach the lower fin membrane. The individual punctulations are larger and more separated on the lower side; the close setting above gives the back a marked dusky color. The membranes of the rayed dorsal and the caudal are similarly dusky. A single row of small blotches sometimes merging together occupies the median dorsal line from top of head to base of caudal. Along the lateral line or a little below it anteriorly the parr marks appear, from seven to ten small, rounded, or elliptical blotches about half the diameter of the eye and more or less evenly distributed between the gill-openings and base of caudal; the depth of color and the approach to circularity of outline increase toward the caudal region; a dark spot on the opercle and one at the base of caudal complete this row. A second row of similat hut smaller blotehes sometimes appears bet ween the lateral row and the median dorsal line. In transparent specimens the black of the inner ventral linings may show through slightly. Tip of chin dusky.

The small fingerlings (pl. r, fig. 2), 35 to $50 \mathrm{~mm}$. in length, show some change in

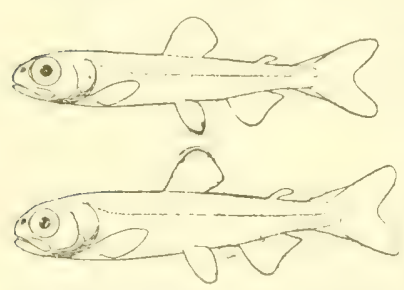

Sockevo fingerlings. Upper figure a poorly nourished example, lowers well nourished.

less than one-fifth the body length. (See text figures.)

In markings the general duskiness encroaches on the ventral region, only the belly, breast, and lower head parts (except the chin) remaining immaculate. The median dorsal marking may be a row of blotches, or these may merge into a nearly solid stripe, which in individuals of $50 \mathrm{~mm}$. up usually fades into the general duskiness. In most of the smaller individuals the parr marks are rounded blotches little larger than the pupil, varying in number from 8 to 12 and more or less evenly distributed along the lateral line. The second row above may or may not be present.

specimens irom Karluk betwen 10 and $50 \mathrm{~mm}$. long show ensiderahle variat ion from the markings just described. The parr marks are elliptical, about twice as deep as wide, except over anal and on peduncle. These long bars are mainly below the lateral line. They much resemble the markings of the dog salmon. These specimens also vary from the more southerly examples in the smallness of the eye and in the fewer and shorter gillrakers. Their identification is not absolute.

At about $80 \mathrm{~mm}$. length (pl. II, fig. 1) the fingerling assumes the graceful outlines of the adult, depth $4.5-5$ in body, average 4.6 ; head $3.66-4.12$, average about 4 ; eye nearly 3 in head, pectorals $1.5-2$, average 1.66 ; dorsal 1.66-2.3, average 1.8 ; anal about 2.5 ; ventrals about 2 ; gillrakers very variable, $12-20$ to $13-22$; longest $\frac{2}{3}$ to once diameter of eye, spanning 3 to 6 interspaces. In fresh water the general color is silvery over dark. Punctulations cover the entire body, except a narrow area between chin and ventrals. The parr marks are more or less elliptical, with a depth about equal to diameter of eye and almost obliterated by the silvery. Occasional fresh-water specimens wholly silvery, sea-run individuals probably always so.

$A$ yearling (pl. v), from Karluk Beach, $165 \mathrm{~mm}$. in length, had depth 5; head little more than depth, 4.5; eye about 3.5 in head; pectoral 1.5 ; dorsal 2.2 ; anal 2.66 ; ventral 2: villakers as in adult-1hat is, having about the same proportion to diameter 
of pupil. In life "back grassy green, thickly spotted; a dark blotch on distal half of anterior dorsal rays, posterior rays colorless; tips of caudal lobes dusky; lower fins colorless; no trace of parr marks; iris washed with golden" (Rutter). In alcohol the dark of the back reaches the lateral line in front, then rises under dorsal to about the fifth row of scales above lateral line, and on caudal peduncle approaches the line to about third row of scales. Numerous round dark spots about one-third diameter of pupil on back from nape to caudal, sometimes falling into about 2 irregular rows on each side, with others scattered, sometimes wholly irregular and often continuing on to top of head; the interspaces about twice size of spots. Dusky of dorsal includes all but tips of last 3 or 4 rays; axil and inner surface of upper part of pectoral slightly dusky; tip of chin and adipose fin dusky. When scales are removed, round parr marks may be noted in specimens up to $200 \mathrm{~mm}$. in length.

Almost from the first free-swimming stage the sockeye may be distinguished from any species except the humpback by the length, number, and fineness of the gillrakers. The humpback at times exhibits a greater number of gillrakers, and these of greater proportionate length, than the sockeye from the same locality. In this case, however, the small sockeye fingerlings may be recognized by the color, and the larger by their coarser scales, greater depth, and larger eye.

\section{The Steelhead Trout, Salmo gairdneri (Richardson).}

There are three accepted species of trout in Alaskan waters - the steelhead, rainbow, and cutthroat. I have been able to find but one type of fry, and am even unable to find distinguishing marks in the young of known species grown in the hatcheries. The fry here described I have called stechead, for the reason that it is found in abundance migrating to the sea from streams in which large numbers of steelheads are known to spawn. The description may he taken in general as applying also to the rainbow and cutthroat trout fry.

This fry (pl. I, fig. 7), at the time of closure of the ventral walls, averages between 30 and $32 \mathrm{~mm}$. in total length. Depth about 6 ; head 3.5 in body; eye 3 in head; pectoral 1.66; dorsal 2; anal 2.25; ventral 2.5. Head pointed; greatest depth through middle in front of dorsal; gillrakers very short and well separated; about 5-10 to be made out by counting the faintly developed tubercles, longest about one-third diameter of pupil, equal to or less than one interspace.

General color silvery, sometimes with brassy iridescence, parr marks 9 to 12, deep and narrow, usually dark and contrasting sharply with the silvery interspares. Body, except belly in front of ventrals, and fins, except the paired ones, with punctulations; dorsal with front rays black; anal with posterior rays less shortened than in salmon, which character with the fewer rays gives the fin a more rounded appearance

\section{The Charr, or Dolly Varden Trout, Salvelinus malma (Walbaum).}

The charr fry (pl. I, fig. 8) has undergone complete absorption of the yolk sac at $26 \mathrm{~mm}$. length. It is slender, with greatest depth through pectoral, much resembling in shape and general appearance the larger sockeye of a somewhat later stage. Depth about 5 in body; head 3.5 ; eye 3 in head; pectoral 1.5; dorsal 1.66; anal 2.25; ventral 2.5; gillrakers about 4 to 7 or 8 , somewhat longer in proportion than in the steclhead, longest equal to about one-half eye, equal to or slightly greater than an interspace.

Of lighter general ground color than the steelhead, the parr marks nccurring as 7 to 10 round blotches about the size of the eye, along lateral line; other similar blotches on back. Lower fins immaculate. Readily distinguishable by the slim tapering shape. general brownish color, size and shape of blotches, and anal fin.

In fingerlings, about $40 \mathrm{~mm}$. long, depth about 4.5, greatest between dorsal and pectoral; head 3.66 ; eye nearly 4 in head; pectoral 1.4 ; dorsal 1.6 ; anal and ventral 
about 1.87 ; gillrakers about $5-9$, the longest about equal to diameter of the very small pupil and spanning one interspace. An irregular row of alternating blotches below the parr marks, faintly present in fry, becomes more distinct and the back becomes thickly mottled with spots about size of pupil; otherwise the color much as in fry. This species is unusually thick (laterally) in proportion to depth, and is not so much flattened as the salmons and true trouts. This character becomes noticeable in the fingerlings, and together with the peruliar motyling makes them readily distinguishable without counting the anal.

\section{THE BASINS STUDIED.}

The two regions from which most of the origrinal material in this paper is derived are the basins of the Naha and the Karluk rivers. From the Naha as a central locality, the conditions existing in adjacent basins received some attention, and salmon from les Bay, Karta Bar, Moira Sound, Boca de Quadra, and the streams of Annette Island were examined. These latter waters have been deseribed in the reports of the operations of the steamer Albatross in Alaska. ${ }^{a}$ The accompanying sketch map of the Naha region illustrates typical conditions as found in most of the smaller sockeye streams in Alaska.

\section{CONDITIONS CONTROLLING THE WORK.}

The Naha as an observation station is ill adapted for a small party on account of its complexity and extent, though rendered advantageous by the Alaska Packers Association establishment and the generous assistance extended by that corporation. The successful conduct of any inquiry, however, requires either a sufficient number of observers to carry on the work simultaneously at all parts of the area to be covered, or a sufficiently small area to permit the party available to cover the entire territory readily; and of indispensable importance in fishery investigations is sufficient apparatus, such as boats, suitable nots, etc., to apply continuously any given line of experiment or study. For the best work on the Naha the absolute control of at least 4 boats would have been necessary, and even with this complement, the distance from the nearest habitable quarters at the mouth of the stream to the spawning ground of the fish is such that the round trip is practically a day's journey, leaving little time for observations en route or at the extremity of the trip. Another complicating feature, objectionable from one standpoint, desirable from another, is the presence of the brackish-water lagoon. Had it been possible readily to reach the mouth of the river above the lagoon, the trap could have been set there, as was to be desired; the lagoon

a Moser, Bulletin U. S. Fish Commission, vol. xvirI, 1898, p. 1-178, and vol. xxI, 1901 , p. 173-398, and $399 *-401 *$. It should be noted that in the descriptions of the Moira Sound region, vol. xvII, p. 78-80, the descriptions for Kegan and Old Tohnson stream have beren transposed; the figures for the catch, however, are correctly assigned. 
would thus have been a part of the salt-water approaches. Under the circumstances, however, it was necessary to operate the trap at the rapids below the lagoon, where it was subject to the rise and fall of tide. This necessity may to a certain extent have altered results.

\section{METHOD USED TO DETERMINE MIGRATORY MOVEMENTS.}

The apparatus used for taking the migrating young was a sort of fyke trap made from a regulation collecting seine used by the Bureau, and was similar in principle of operation to the gear used by Rutter in the California investigation and by Babcock in the Fraser (p. 30). The conversion of the seine into a trap was accomplished by sewing on a bag of coarse bobbinet to surround and extend beyond the netting bag of the seine. This latter was then opened and a small fumnel of bobbinet laced to the opening. The large bobbinet bag was closed at the hinder end by tying with a cord, so that it could be readily opened and the contents shaken into a bucket. With a short seine pole and bridle at either end the contrivance was then ready to hang across the current for operation. For successful results the current must be sufficiently rapid to keep the bag distended-otherwise the fish will not enter it -yet not strong enough to burst the fabric. In water too swift the smaller fish are pressed against the web and drowned. The rise and fall of the tide at station 2 in the Naha vitiated the statistics to a degree. With such a contrivance careful weight must be given to the state of the water. Muddy, swift water as at flood time always shows an increased catch, due doubtless in part to the favorable influence on the operation of the apparatus as well as to increased movement of the fish.

This apparatus as ordinarily operated is very defective. Estimates of numbers of migrating fish based upon its results can be only very distantly approximate. In no case can the entire current of a large stream be occupied, and only in exceptional cases will the net at all times reach from top to bottom. In the Naha and Sacramento tests, the lead line was frequently some distance from the bottom; in the Fraser River inquiry, however, it appears that the net was set on the bottom. Only by repeated tests can it be determined on which side of the stream the net will be most effective. On the Sacramento I made a few tests as to its efficacy at the side and center of the channel, respectively, but results were not definite, since other factors necessarily entered into the question. A complete experiment would require several of these traps to be operated simultaneously in different parts of the stream. In any current where fine-meshed fabric can hold, moreover, the stronger fish can breast the stream and escape. This defect of the device used is called to attention by Mr. Babcock in his report for British Columbia. The objections stand only against estimates of total number of migrants based on the eatch made. 
THE NAHA.

CMARACTER OF THE STREAM.

The Naha River rises in the uppere central part of Revillagigedo Island, Southeast Dlaska. Its extreme upper part has not been explored, but doubtless possesses no characters of note differing from the usual mountain stream of that region. As a whole the stream is somewhat peculiar in the larere number of lakes (four) in its course, but the total surface area of these four lakes is no greater in proportion to the volume of the stream than may be found in other instances, for example, the Karta River. The upper two of these lakes are of no creat importance to the present salmon run, since a fall of some 30 feet, together with a series of broken cascades below the ower one, now prevents the ascent of the salmon. The two lakes are connected by a short reach of the stream which offers no obstruction to the passage of fish between them. The lower one, known as Patehing Lake, is well stocked with cutthroat and Dolly Varden trout, and seems to contain also the dwarf form of the sockere. Tn the spring of 1903 a plant of sockeye fry was made in the comnecting stream, making the original presence of the dwarf form subject to some doubt. Patching Isake is the largest of the four lakes and is probably the deepest. It is between '2 and 3 miles in length and less than one-half mile in width. Depths of 140 feet have been sounded.

In the lower course of the river, and yet accessible to salmon, are two lakes, Heckman Lake, about $1 \frac{1}{2}$ miles in length, and Jordan Lake, of about 1 mile. At the mouth of the stream is a brackish-water lagoon, about 1 mile in length, known as Roosevelt Lagoon. This latter receives the salt water from Naha Bay at ordinary and spring tides. Its surface water shows brackish everywhere except in time of flood waters, and the ereater depths are doubtless quite salt.

The greatest depth in Ileckman Lake is about 130 feet, in Jordan Lake somewhat less. The area and shallowness of these lakes, together with their exposed situation, admit of an early acquisition of high surface temperatures. Fortmam IIatchery is located at the head of Heckman Lake adjacent to the most important natural spawning ground of the sockere. These beds are about 6 miles from tide water, one-half of this distance being oceupied by the lagoon and lakes. As originally found they were about 400 vards in length and of perhaps 15 or 20 yards average widh, the whole more or less covered with logs and drift. In addition to these, small parts of the section of the river comnereting Jordan and IIeckman lakes were used; also MeCune ('reek at the upper end of Ileckman Lake, and unimportant areas of Emma Creek, a small tributary of Jordan Lake. All of these beds are also frepuented by the eoho and humploack salmon, but the erreater number of these two species do not reach INeckman 
Lake. Their most prolifie grounds are that section of the main river between the lagoon and Jordan Jake, a large area being afforded by the stream just below and immediately above Dorr Falls. In addition they oceupy the many small creeks which enter the lagoon, the river, and the lakes. King and dog salmon enter the Naha in too small numbers to indicate their preferences, but king salmon have been seined at the hatchery, and it is probable that in all such streams they go as far upstream as possible. But one king salmon fry was taken during the present work, that from the lower river on June 11, 1903. A few dog-salmon fry were noted migrating from Gibson Creek. They formed a scarcely notable percentage in the catches in the main stream.

A considerable part of the shores of both Heckman and Jordan lakes is of gravel and apparently not unsuitable for "nests." It may be that when the stream was crowded the shores were used, but at no time were sockeyes observed to spawn about the lake shores as in other basins. The portion of the stream between these two lakes was not inspected, but the area of suitable ground for beds is said to be small, the chamel being very rough. A few cohos spawn just above Jordan Lake, but inspection by the hatchery superintendent has shown that the sockeyes do not frequent this section of the river.

\section{YIELD́ OF SALMON.}

As a sockeye stream the Naha has been one of the most productive of the smaller streams of Southeast Alaska, a fact which may be due in part to its having been so unremittingly fished. The long, narrow bay which receives the river furnished excellent fishing grounds, and the shallow upper end an excellent foundation for a fence. In the following table is shown in round numbers the yield of the Naha and the important aljacent streams for each year from 1887 to 1900:

Yield of the Naha and Important Adjacent Streams, 1887-1900.

\begin{tabular}{|c|c|c|c|c|c|}
\hline Year. & Naha. & Yes Bay. & Karta Bay. & Quadra. & Total. \\
\hline 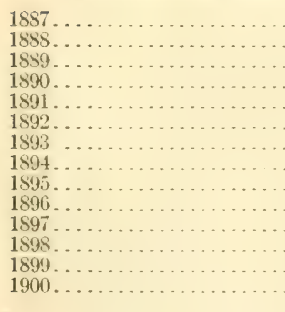 & $\begin{array}{l}75,000 \\
75,000 \\
76,000 \\
68,000 \\
96,000 \\
34,000 \\
49,000 \\
56,000 \\
15,000 \\
43,000 \\
16,000 \\
18,000 \\
13,000 \\
15,000\end{array}$ & $\begin{array}{l}26,000 \\
22,000 \\
42,000 \\
46,000 \\
61,000 \\
44,000 \\
69,000 \\
80,000\end{array}$ & $\begin{array}{r}84,000 \\
23,000 \\
106,000 \\
56,000 \\
63,000\end{array}$ & $\begin{array}{r}97,000 \\
137,000 \\
65,000 \\
98,000 \\
166,000 \\
175,000\end{array}$ & $\begin{array}{r}75,000 \\
75,000 \\
76,000 \\
68,000 \\
96,000 \\
34,000 \\
75,000 \\
78,000 \\
154,000 \\
310,000 \\
165,000 \\
266,000 \\
314,000 \\
335,000\end{array}$ \\
\hline
\end{tabular}


The Catch of Sockeyes from the Naha River, in Thousands.

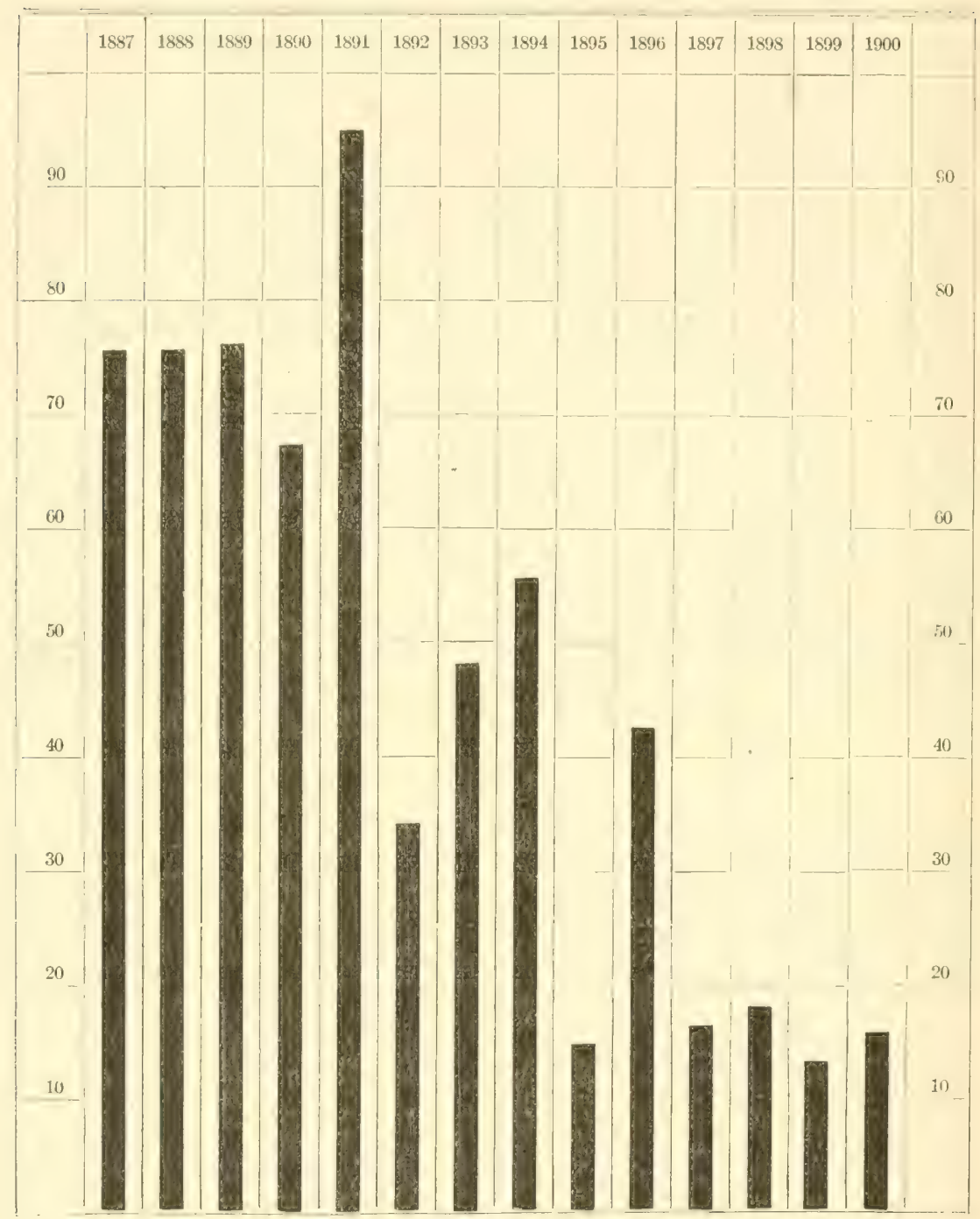

The large eatch in 1891 was due to close fencing as well as abundance of fish. It will be noted, as shown in the accompanying block table, that the decline in numbers, while in general gradual, is most marked in four-year periods after this date. It also will be remarked that the heary catches do not coincide in the different basins, pointing to a shifting of the general run under different circumstances. Conclusions based on the commercial catches, however, require not only accuracy in the statisties, but cletails as to the efforts made to take all fish arriving in the given waters. These details, unfortumately, we do not have. Yet these figures undoubtedly indicate the 
possibility of fishing out a griven stream, and with this is carried the implication that at least the greater part of the supply of any stream must be derived from the fry produced in that stream.

\section{CATCH OF YOUNG SALMON IN THE 'TRAP.}

To determine facts regarding the migration of the young salmon into salt water, a trap such as is described on page 21 was placed below ITirsch Rapids on the Naha, at station 2 (see map), p. 112). The location was chosen on aceount of its aceessibility, as stated above. The catch marle by this apparatus is shown in the following table (no. 1). As the traj) Was operaterl in salt water, the catches included sticklebacks, pereh, hlemies, occasional trout, ete., which are grouped under "Other fishes."

Table 1.-Catch made by Trap at Station 2, Naha Bay, 1903 and 1904.

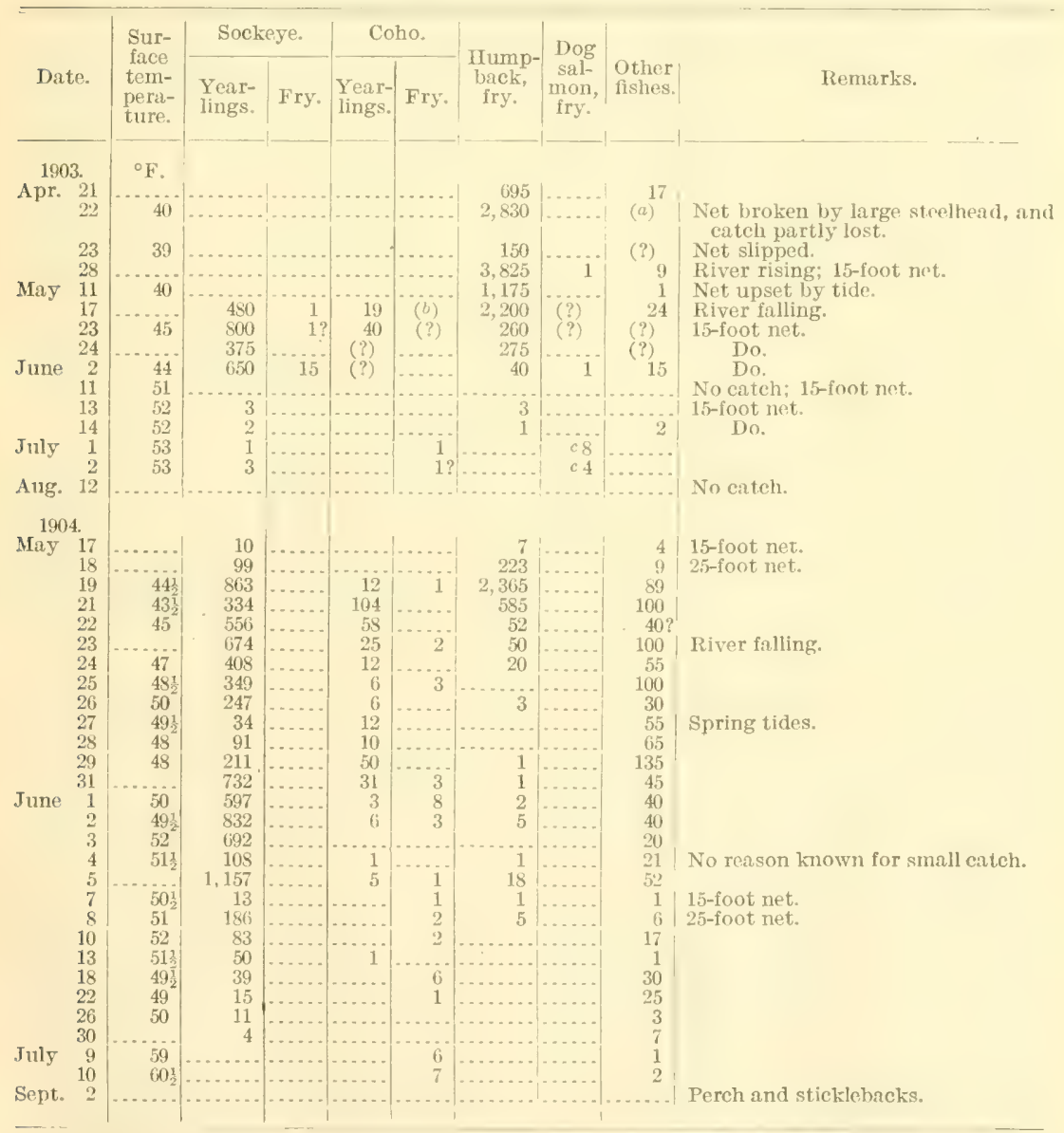


During the season of 1903 a 35 -foot trap was used except where otherwise indicated in the table; in 1904 a 45 -foot trap.

In 1903 , in 17 sets of the trap at Hirsch Rapids, station 2, between April 21 and August 12, on only three occasions were sockeye fry taken, twice a single example and the other time fifteen. In six trials from April 21 to May 11 no sockeyes were taken; on May 17,

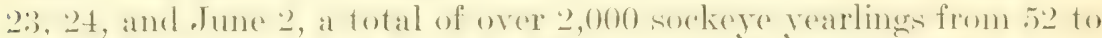

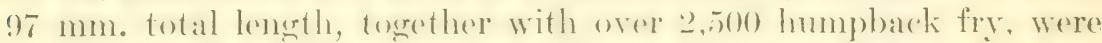
taken. Thus it would seren if any great number of sockeye fry were migrating more would have been found in the net.

In 1904, between May 17 and June 30, at the same point, over $\$, 300$ sorkeye vearlings were taken, as well as wer 3,300 humploack fry and nearly 350 coho fry, but no sockeye fry.

In 1903 a trap was placed in the Naha at station 1 as soon as the lacoon was sulliciently alear of ice to permit use of a boat, April 12 to 19 , thus probably securing the arliest movement of humplock fry. It this time all the lakes above were entirely covered with ice. April 19 a sot at station :3, just below Jordan lake, took only humpback and doesalmon fry. It can not be that the run of sockeye fry was over before the work was bexun, siner wreat numbers were only recently hatched, nor is it likely that it oceurs later in the summer, for no fry of any kind were taken in a trap) set August 12, 1903, ouly 9, 10, and September 2, 1904, nor in one set in the outlet of Yes Lake, July 18 to 21, and August 5 to 26, 1905.

A remote opportunity for error lies in the fact that, Roosevelt Lagoon being salt water at the bottom, a deep-water fish, which the young sockere undouldedly is to an extent, might pass the rapids at hicrh water and go under the trap). But this is (xtremely improbable, since in British Columbia waters, where the migration has been studied, the fry passed in the same manner and at the same season as the yearlings. It is further shown to be molikely by the fact that a trap set below the mouth of Jorkan Lake at station :3, May 15, 16, and 17,1903 , took only 2 or 3 sockeye fry, while securing some 12,000 humploack. It the same point. Fune 2 and :3 only 14 sockeye fry were taken. At this date the humpback run was practically over. Nor did a trap set at the foot of Heckman Iuake, station 4, May 12 to 14, show any consiclerahle morement, 6 sockeye fry being taken, with 250 yearlings.

In 1903 the first movement of sockeyes at salt water was noted May 17. May 11 a trap set at station 2, in which over 1,000 humpback fry were taken, failed to secure any sockeres. The migration probably becan on the high water of May 12 to 15 : :300 yearlinge were taken on the latter date below Jordan Lake. May 17, 220 were taken in a trap) spamning about one-third of the (hammel at station?; (n) the sad over 800 were sereured by a trap of half the size, spanniner about one-fifth the channel: in this small trap 375 were taken on the 
24 th and 650 on June:2. Dfter this latter date the eateh fell away; June 3, only 9 yearlings were taken below Jordan Lake, and at station 2 on the 13 th and 14 th but 5 were obtained.

These trials inclicate that the migration in 190:3 began about the middle of May and practically ended early in June, though stragglers continued to show into July. The maximum oceurred about May 23 , after high water in the river and on high tides in the bay.

In 1904 the rum had begun before the work was commenced. The first trial was made at station 22, May 17, and though the trap was badly damaged, 10 yearlings were taken. On the 19 th, with a trap eovering about 60 per cent of the channel, stos yearliness were secured. The run continued with variations till June s, when a maximum catch of 1,157 was made. After this date the catch rapidly decreased, only 8:3 being taken on the 10 th, 50 on the 13 th, 1 on the $: 30$ th, and none July 9 and 10.

In eomparing the rums of these two seasons it must be noted that the eonditions varied materially. In 190:3 the heary iee kept the river closed until an unusually late date. The lakes were not entirely clear from ice until about May 12, and the temperat ure of the river dis not rise above $40^{\circ}$ until after the middle of May. In 1904, at the time of arrival of the working party, May 16, the river had reached a temperature of about $14^{\circ}$ and the ice had been gene for several weeks. By the latter part of May the temperatere had risen to 50 $50^{\circ}$, and by June 2 to $52^{\circ}$. In 1903 this latter temperature was not reached till June 13, yet in 1904 the rum eontinued orer almost the same period as in 1903, reaching its maximum perhaps somewhat later. This fact must be related to the much greater output of the hatchery for the latter year. In 1902 about 10,000,000 fry were liberated, under primitive conditions; the following vear nearly $30,000,000$ were planted under somewhat hetter conditions. The product of natural spawning is a negligible factor.

\section{YES BAY STREAM.}

Yes Bay is about 30 miles north of the Naha on Behm Canal. The river is somewhat larger than the Naha and about 1 mile in length below the lake. Yes Lake is nearly $t$ miles in length and of average width less than one-half mile. The greatest depth is 230 feet. Above this lake the river ofiers about three-fourths of a mile of excellent spawning ground, at the end of which the further ascent of fish is cut off by high falls. These falls were passable at one time, perhaps, as Dolly Tarden trout have been taken above them. At a considerable elevation are other lakes of less extent that have not yet been explored.

Yes Lake has no tributaries that are oceupied by spawners except the main stream. The sockeyes use the upper river above the lake. 
This section is also frequented by cohos, stectheads, and an occasional king. I Iumplacks spawn mainly in the lower river. The Yes Bay hatehery is lecated on the section of the river immediately above the lake.

The trap maintained at the foot of Yes Lake July 18 to 21 and August 5 to 26, 1905, made no eatch of migrating fry or yearlings. It was evident that the migration was entirely over at that time. A trap of the same kind installed duringe the spring of 1907 at the same point made heavy catches of young, but at the time of writing this report the material has mot been sperifieally identified. Mlost of the data regarding the summer residence of young in the lake were drawn from observations in this locality.

\section{KARLUK RIVER.}

SUITABILITY AS A SPAWNING STREAM.

The Karluk River is a much larger stream than the Naha. ${ }^{a}$ It is about 20) miles in length and several times the volume of the Naha. The lower course is one continual rapid, but presents no falls to obstruct the ascent of the fish. The upper course is of moderate current and affords excellent spawning ground, while in addition there are many sloughs to act as nursery ponds for the young. The lake is estimated to bes miles in length and 2 in widh h, depth unknown; two much smaller lakes are tributary to the main body. There are numerous small streams contering the main lake, some of which, as the outlets of the tributary lakes, are of considerable length and suitable for spawningersomel, while other's are swift mountain torrents with rough beds which ofier hut small areas for the fish. 'The shores of the lakes also are utilized for spawning. The river proper falls into a lagoon some 2 miles in leneth, into which the salt water flows from alout half tide, so that it is largely brackish. The outlet of this lagoon to the sea is narrow and gives rise to strong currents in each direction somewhat as in the Naha. Near the head of the lageon is lexated the Karluk hatehery. The Karluk River has been

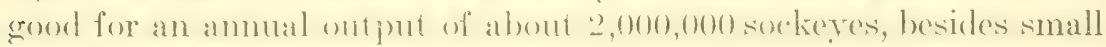
runs of king and coho and occasional large runs of humpbacks.

MOVEMENTS OF YOUNG SALMON AS SHOWN BY TRIAL CATCHES.

The least ineonveniem means of ateess to kitruk Latie is by portage from Larsens Cove, Uyak Bay, to Nicolai's barabara, a trip of 5 miles; thenes by river, too shallow for a boat and too deep for grood walking, 6 miles more to the lake. The labor required to bring to the lake the neeresiatries of life, and the conserquent lack of scientifie

a A full description, by Dr. Tarleton H. Bean, may be found in Bulletin U. S. Fish Commission, vol. Ix, 1889, p. 165 et seq. 
outfit, will account for the meager results the observers obtained in certain lines.

At this station the main attention was given to adult fishes. These were taken in a small pound or trap spanning about one-fourth the outlet on the shoal side and built for taking the incoming fish. A trap for vouner was operated a few times in connection with this pound and was also set a few times in tributary crecks. The party was equipped with a single net so constructed, and the lébris from the lake soon accomplished its ruin. On account of this shortace of proper gear the movement of fry and vearlings from Karluk Lake was not followed with any definiteness. Five sets were made with a 25-foot net rigged as above described, with the following results:

June 5, over night, sculpins, sticklebacks, 150) salmon parrs, a few salmon fry, a few trout fry.

Tune 25, over night (between pound and shore), 73s sculpins, 530 sticklebacks, 23 trout, 32 salmon parrs, 16 salmon fry.

June 27, over night, sculpins, sticklebacks, s trout, 2 salmon parrs, 2 salmon fry; $12 \mathrm{~m}$. to $5 \mathrm{p} . \mathrm{m}$., a few sculpins and sticklebacks.

June 28, over night, sculpins, sticklebacks, 1 salmon parr, no fry. June 30, $12 \mathrm{~m}$. to 4.30 p. m., 3 sculpins, 165 st ickletacks, 1 sulmon parr.

It will be noted that all these results show but a slight movement of sockeye fry from the lake. It may be they had reached the river prior to the first set of the net, though not all harl passed down the stream. 'Throughout May and . June the sloughs of the upper part of the Karluk River contained many sockeye fry or small fincerlings. In a haul May 22 nearly a thousand were taken, many with remnants of yolk. June 21 larege schools of small fingerlings were numerous in the upper river, and some were taken with the dip net. June 30 a few fingerlings averaging nearly 2 inches in length were taken in a pool of the river. Such fish seem to have disappeared soon after this date, since the observers made no further note of them. Fry and small fingerlings were abundant in the lagoon during June, July, and into August, but as these may have been the hatehery output, their presence indicates nothing regarding migration habits, except that they all apparently passed out into the sea during the summer.

It would seem that the station party would have noted any large movement from the lake had it occurred, since their camp was established at its mouth early in May, before the ice had left it. But this is not necessarily true. At that season daylight lasts from about 3 a. $\mathrm{m}$. till $10 \mathrm{p}$. m. The young salmon travel little in daylight, and it might easily be that a considerable movement could have occurred without remark. It might be thought possible that the numerous fry in the river were the product of egos spawned below the lake by fish arriving after low temperatures obtained. That this is highly 
improbable, however, appears from the fact that such egess could not have hatehed and the roung developed by the time the fry were noted. Ripe fish woukl scarcely fail to enter the lake up to the time that ine formed upon it. It was shown that while ice is on the lake the temperature of the river is not much above $34^{\circ} \mathrm{F}$. It this temperature the sockeye exgrs would require about two yars to develop into migrating fry.

\section{CONDITIONS REPORTED IN BRITISH COLUMBIA.}

The observations male in British ('olumbia, under the direction of J. P. Babeock, on the Fraser and Wannuck rivers (see Annual Reports of the Fisheries ('ommissioner for British ('olumbia, 19021904) should be noted here. In the spring of 190()$^{2}$, following the big run of 1901, fry were abundant in Lake ('reek, the outlet of Seton Lake, and apparently migrated downstream at the same time with the rearlings. In 190:3 swimming fry were seen in Lake (reek as early- as January, remaining till $A$ pril. They seemed to move downstream in April and May, after which none was seen either in Lake (reek or in Seton Lake. The movement of the rearlings began on the spring floods early in April and continued to. June, being the heaviest the first two weeks in May. Observations at Lytton, in the main river, found fry and yearlings, the latter least in number, traveling together between $\Lambda$ pril 1 and July 13 in both the Fraser and Thompson rivers. In 1904 no fry or yearlings were found in the rivers. This was supposed to be due to the absence of spawners in the waters above in 1902 and 1903. It would seem, however, that if the movement of fry in 190:3 was marked there should have been a corresponding number of yearlings to show in 190-t. It is impossible to believe that the product of the 1902 e exgers all left the waters as fry. Trials in the Wannuck River at River's Inlet, north of the Fraser, in 1904, discovered an abundant movement of both fry and yearlings between April $1: 3$ and July 1. The fry were in greater abundance than the yearlings and the height of the run was between May 22 and June 16. This greater abundance of fry as compared with the number of yearlings is thought by Mr. Babcock to be due merely to the operation of the trap. Both fry and yearlings drift downstream tail first. The tail coming in contact with the net, the fish would attempt to rush upstream and aroid the obstacle. If the net were set in water of moderate current the stronger yearlings would be able thus to avoid it and escape, whereas the weaker fry would be more likely to enter it. In swift currents both are forced into the trap. 


\section{SUMMARY OF OBSERVATIONS.}

From these various records it would seem that in the larger rivers, as the Karluk and Fraser, many sockeye fry leave their liursery waters as soon as they are able to swim and feed, or at the beginning of the fingerling stage; that in the smaller streams, as the Naha, this number is small and, in comparison to the number resident for one season, negligible; that in all cases a portion, perhaps the greater. remain in the lakes for one winter and migrate in the following spring as yearlings. Whether any spend a second winter in the fresh water has not been demonstrated. This residence of large numbers of young in fresh waters with a definite and apparently anticipated movement seaward the second spring of their existence is micue in this species. While some king and coho young spend the summer in the vicinity of their birthplace there is no evidence that these summer residents do not pass to the sea as a rule during the fall, or for that matter at any convenient time. Their continued stay seems to depend largely on the period of rainless weather that obtains on the Pacifie coast during the summer months. Only a small remmant of the lake-inhabiting fingerlings of these two species spend a winter in fresh water. Humplack and dog salmon all leave for the sea almost as soon as they are able to swim. This habit of the sockeye is doubtless connected closely with the habit of lake spawning, or is even the immediate effect of that cause. Further, it probably has given rise to the dwarf form, of which no analogue exists in the other species.

\section{YOUNG SALMON IN FRESH WATER.}

THE SOCKEYE.

MOVEMENT OF FRY ABOVE THE LAKES.

The sockeye fry when hatched or planted in the tributaries of a lake linger a little while on the nursery ground. Small plants made in pools near Loring in 1903 remained a considerable time after the absorption of the yolk sac, and the same fact was noted at the nursery pond at Fortmann Hatchery the following year. Similar observations were made also at Karluk. The first creek entering at the foot of Karluk Lake is a small creek consisting of three pools connected by short rapids and fed entirely by springs. A few sockeyes frequent it for spawning, the greater pereentage, apparently, being weak fish that are unable to continue the journey. It may be, too, that this creek remains open late in the fall and finds faror with late-coming fish. On July 14 a net was set across the mouth, taking in daylight. 4 adult salmon, 1 stickleback, and 1 sculpin. At night 6 adults and 87 young sockeyes, 7 sticklebacks and 1 sculpin were taken. Of these young 11 were feeding and had reached an average length of $41 \mathrm{~mm}$.

$10731-07-3$ 
They eontained insects, larvar, and crustareans. The remainder were recently out of the fry stage, and only a fow had begun to eat. This indicates that sone of the youmer remained some time longer in the ponds than they would have done in a stream of diflerent character. Throir late development is doubtless due to the cold spring water. Nets set acrosis one of the principal spawning ereoks on July 16 and 27 took very few fry.

After some days, perhaps when urowing necessity for food demands activity, sockeye young, as fry or small fingerlings, drop down the stream into the bake or maybe the sea. During the season of observation on the Naha none was ever seen in the stream below the lakes, though cohos in abundance were resident there throughout the summer. Nor were any ever seen by the writer about the margins of any Alaskan lakes except in the one instance mentioned below. Sockeyes apparently are never resident in the streams and never found in them except during the migratory movement.

While adequate observations are lacking, it is probable that the fry travel in schools. In the Karluk they were observed by Rutter to school while in the sloughs, though they have nowhere been seen to migrate in schools. In the lakes they remain during daylight in comparatively deep water. Rutter notes that they were at no time seren in abundance about the shores of Karluk Lake; Balcoek states that they were not seen in Seton Lake after May. In the Naha lakes they were seen but once, June 11, a small school in Heckman Lake near the outlet, and a few in Jordan Lake in company with numerous cohos. They were taken in Alturas Lake outlet by Evermann on July 20 with fingerlings of the same species. Later in the season young sockeyes were obtained in Alturas Lake only by sinking the seine to the bottom in water of considerable depth, 15 to 60 feet. In Ies I ake in 1905 they were taken by surface hauk of a 130-foot seine aftor dark in the latter part of Luenst and september, and the same meams were nsed suceessfully in the Naha lakes later in that seasom.

\section{FOOD ANI FEEDING。}

In the lakes and in all waters where such food is a valable, youner serkeyes subsist largely upon small crustacea and associated forms, most of which have a diurnal movement to and from the surface, varying with the light. In the evening they rise to near the surface, and, with the coming of daylight, or shortly preceding day, retire an greater depths. $^{a}$ In 1905 from August to November a number of tows with fine nets in Yes Lake and the Naha lakes showed that rrustaceans are ordinarily absent foom the surface during daylight.

a The diumal movement of plankton Crustacea, by Chancey Juday. 'Transactions Wisconsin Academy of Sciences, vol. xiv, 1904, p. 534-568. 
They could be taken in small numbers by sinking the net several fathoms. In Klawak Lake, however, on October 1 copepods seem to have been abundant near the surface at any time of day, but this was noted in comparatively shallow water, whereas the trials on the other lakes had been made in water of greater depth. Is these forms have little horizontal movement it may be that their presence in Kilawak Lake during the day was to be accounted for by the shallowness of the water.

On the approach of darkness many of these crustaceans congregate near the surface, and with that come the young sockeyes. Taken soon after dark, these young fish commonly had the stomach filled with crustacea, with a number of insects, mostly flies and winged ants, in the esophagus. Over the entire surface of Tes Lake on a quiet evening of August or September the presence of young fish could be marked by the ripples. Sometimes they would jump clear of the water, but more usually merely rise to the surface, apparently to snap) up the floating insects which they then sought. The depth at which the fish remain during daylioht is unknown, but is probably not great. Ls noted above, they were obtained in Alturas Lake in 15 to 60 feet. Whether any lived at the greater depth is unknown, since the seine had to be landed through lesser depths. It is unlikely they much exceed such depth, since in summer the lower parts of small lakes are unsuitable for the support of animal life. ${ }^{a}$

Small lingerlings taken in Karluk River May 22.2 were feeding on crustacea, insects, and insect larve. June 21 their food was almost wholly insects and larve; in the lagoon July 24 it was mainly inserts, but with some crustacea. Specimens of slightly advanced size (average $42 \mathrm{~mm}$.) from Wood River, Western Alaska, subnitted by the collector without notes, contain both crustacea and insects. Some snall fungerings taken July 14 in the small creek tributary to Karluk Lake contained insects and in one instance crustacea.

In Yes Lake October 12 tows immediately off the mouth of the inflowing river in water of $47^{\circ} \mathrm{F}$. took very few crustacea. These were probably not from the river water, for it, being somewhat colder, would sink to the greater depths on entering the lake. October 17 a net set over night in the river just above the lake took very few crustacea; river temperature $43^{\circ}$ and lake $46^{\circ} \mathrm{F}$. September 12 a net was set at the foot of the lake in the outflow for fift $y$ minutes and $\mathrm{m}$ crustacea taken; at the same time tows were made just above this set net and a few crustacea taken, but much fewer than were usua!? taken in the main body of the lake. It would seen from these few trials that there is a scarcity of erustacea in both sections of the river,

$a$ See E. A. Birge, Gases dissolved in the waters of Wisconsin lakes. Transactions American Fisheries Society, 1906, p. 143-163. 
but the matter needs further investigation. Even these slow-moving forms may be able to avoid the action of the eurrent at the foot of lakes and remain within the lake boundaries.

\section{FOOD SUPPLY IN RELATION TO TIE HATCHING SEASON.}

The relation of food supply to the season of hatching has not yet been worked out. In the latitudes in which the sockeye is found it is improbable that any fry reach the feeding stage in adrance of the opening of the streams from ice, unless when the spawn is deposited on the lake shores. In this latter event they would seek subistence in the lake waters. It is shown above that these fingerlings feed to some extent upon surface forms when in streams or lakes at a season when such food is present. Their more natural food appears to he the subsurface plankton. The abundance of this material may be an important factor in deteminime the time of departure from fresh water.

This question has an important hearing in fish cultural work. The use of sprine or lieatrol water may shorten the incubation periol to such an extent that fry reach the feeding stage in advance of the natural production of their food. To liberate them in that event must be disistrous; to retain and feed them artificially nullifies the economic advantage obtained in hastening the incubation.

The temperature at which the most thrifty fry may he produed is another question that should be taken up. There are some data to show that low temperatures increase the number of temperature units required to eflect the hatehing. In long periods of depressed temperatures errors in the thermometer or its reading will be a creater factor than in short periods of olservation. But if very cold water does retard the hatching, then such temperatures may or may not he ardrantaceous. The suecess of certain methords in handling an insect-feedingspecies in waters that never freeze can be no criterion as to the best methods for a species of different habits living in different waters.

\section{GROWTH IN FRESH WATER.}

Fifty-nine young sockeyes taken in Yes Lake August 24, 1905, varied from about 32 to $66 \mathrm{~mm}$. total length, with an average of about $46 \mathrm{~mm}$; 66 seined on September 10 varied from 35 to 75 , with an average of 50 11nt.; 59 talien September 26 and 27 raried between 34 and $82 \mathrm{~mm}$, with an arerage of $45 \mathrm{~mm}$. Assuming that these by the following sprine would reach the same size as the Naha fish taken in lon:? when under the most nearly natural comrlitions, an average length of 65 mme, they would have to increase from 15 to 20) $\mathrm{mm}$. in length from September to May. 
Since the deeper water of the lakes will not fall much below $39^{\circ} \mathrm{F}$., the point of maximum density, and since with the approach of cold weather the diffusion of oxygen will become more general, there seems to be no reason, unless there is a cessation of actirity due to the cold, why fingerlings should not feed more or less during the winter. Some species of crustaceans are known to reach their maximum numbers during the winter. 'This question has not been investigated for Alaskan lakes, nor are any data yet arailable upon which to base conclusions. Fry from the previous season's spawn in les Lake are ordinarily able to begin to feed about the middle of April, at which time they are somewhat over $30 \mathrm{~mm}$. arerage length. By the latter part of August they have reached an average length of about $45 \mathrm{~mm}$., a 50 per cent increase in a period of about four months. That this is crudely approximate is shown by arerages in the three catches cited above.

Should the figures for the Naha yearlings show the approximate size of the Yes Lake migrants, these have little greater growth to make between August and May than they make between April and September. This would require little increase in size during the winter, since the lakes seldom freeze over before January, and up to that time feeding on the lake plankton can be continuous. Dr. Evermann's data from Alturas Lake, as showing rapidity of growth, are rendered inaccurate by the necessity of comparing small fingerlings from shallow water with the larger fish from deeper water, but show clearly that the yearlings there attain a larger size than in the Alaskan lakes studied. His specimens of July areraged $4 \mathrm{smm}$; those of September 9, $83 \mathrm{~mm}$.

It is interesting to note that while the roung taken in Yes Lake in September did not fall below $45 \mathrm{~mm}$., 46 specimens obtained in Ifeckman Lake October 2 averaged only $36 \mathrm{~mm}$. and 28 taken on October 7 averaged but $40 \mathrm{~mm}$. With this diminished size was noted a corresponding slimness and lean condition (fig., p. 18). It is also to be stated that the surface tows for food material in IIeckman Lake, as compared with the material from Patching and Ies lakes, showed a diminution in number and general size of the crustacean life. These facts raise the question of the possibility of overstocking waters with fry. Of course, in case the surplus of young fish leave the parent waters as fry, as would seem to be indicated by the observations of the British Columbia parties, there could scarcely be any danger from this source. But the writer's observations in the Naha failed to reveal any such movement there and it is not unreasonable to suppose that some condition exists there which alters the habits of the fish in that respect. If that is true, and all the sockeye young spend one winter in the lake, then, with the increased millions which artificial hatching is able to turn out, a serious menace is oflered to 
the natural food supply of the waters, since no steps are taken, or perhaps can be taken, to increase that supply. It is notable that Patrhing Lake, where wholly natural conditions yet exist, showed a more farorable supply of planktom life than Ileckman Lake. In this comnection it must also be noted that yearlings leaving the Naha in 190(3) averaged about (6.5 mm. in length. In the following year there appeared a considerable reduction in the size, the average being under $60 \mathrm{~mm}$. 'This difference in the figures, however, might he due in slight part to the greater number measured in 1904.

The size of the yearlings at the time of their movement varies more or less in different localities. In the Naha, in 190:3, 943 specimens averaged (6.5 limm., with extremes of 48 and $100 \mathrm{~mm}$.; in 1904, 2,714 specimens averaged 59 mm., extremes 47 to 115 . (See diagram $\mathbf{A}^{a}$.) In the Fraser River, as reported by Babcock, the average is $76 \mathrm{~mm}$. Fifty-seven examples from the Wallowa River, Oregon, baken April 20, averaged 100 mm., with extremes of 99 and $132 \mathrm{~mm}$. Besides these, in the same lot, were 6 females averaging $163 \mathrm{~mm}$. (extremes 155 and 178 mm.), which were distinct in size and did not intergrade with the remainder. That they were not the dwarf form is shown by the larege number of exges in the ovaries, the large sockeve bearing always far more than the dwarf is known to contain.

The presence of these large individuals raises the question of a possible second winter's residence in the fresh water. Toung sockeyes were found in the Wamnuels up to $150 \mathrm{~mm}$. and in the Karluk up to $221 \mathrm{~mm}$., with the spring migrants. The Karluk fish intergrade with the smaller, indicating merely unusual growth. The only disturbing factor in the Karluk data is the fact that some of the larger of these young fish, taken June 25 at the mouth of the lake going up) stream, show such enlargement of the testes as to indicate approaching sexual maturity. The laresest male and the two females taken in the same lot show no unusual precocity and the ovaries indicate the large form. The maturing males may be the dwarf form, but it is more probable that they are precocous individuals of the ordinary type.

In the yearling sockeye the sexes run approximately equal. Of $1,5,50$ of the 1904 catch examined, 51 per cent were nales and averaged (0.2 mm. erreater than the females in length, the sexes standing, respectively, 59.7 to $59.5 \mathrm{~mm}$. It appears that the greater size of the male becomes early characteristic.

\section{MIGRATION OF YEARLINGS.}

The migration of the yearlings seems to be wholly a matter of instinct. In 1903 the Naha reached a temperature of $40^{\circ} \mathrm{F}$. about the middle of April. By the end of that month most of the ice was cut of the lakes, but the temperature had not risen further. By 


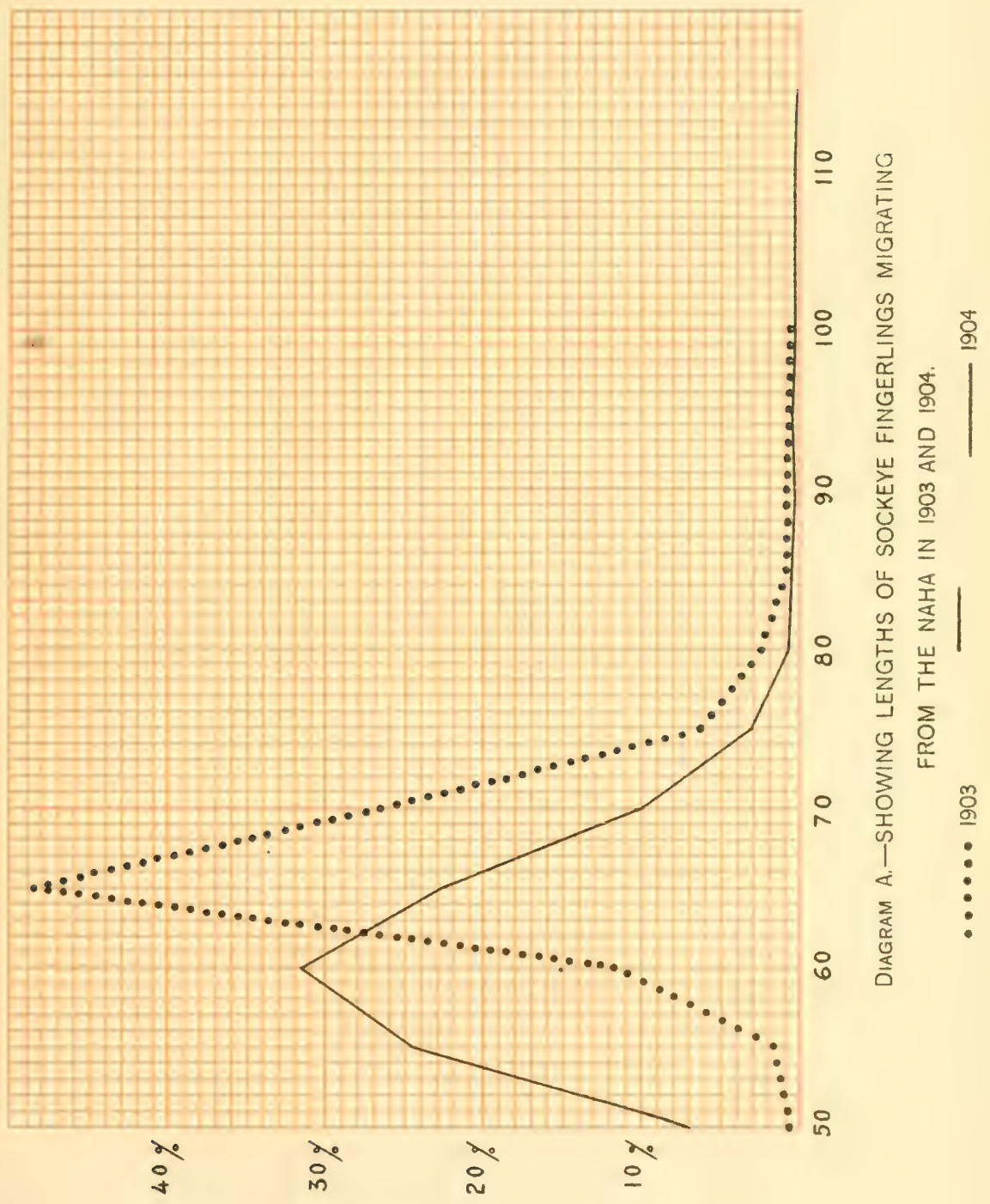



the middle of May, when the temperature of the lagoon had reached $45^{\circ} \mathrm{F}$., though the upper river was still about $40^{\circ}$, the young fish began leaving in large numbers. The run, however, after lasting about two weeks, fell ofl abruptly, before any marked rise in temperature had occurred. In 1904 ice had left the lakes very much earlier, but the temperatures were not notably higher the middle of May than in the previous year; yet on May 17 the movement was at full height and continued so till the end of the first week in June, when the water had reached a surface temperature of over $50^{\circ}$. It then fell away little less abruptly than in the previous year. During this period the fish showed no corresponding increase in size as the season advanced, i. e., they maintained about the same average for the four weeks covering the main run, only the remnant stragglers late in June having increased in average length.

In natural spawning the first depesited spawn must be in no small part destroyed by the activities of late-coming fish. Of the eggs deposited after low temperatures obtain, the product of the earlier will perhaps to a certain extent be evened with the later hatching in that it will not develop rapidly during the winter, and with the rapidly warming water of spring the incubation value of each day angments to lessen the total number of days required in the development of the fry from the egg. Hence, while some fry may be ready to move with the opening of the river from ice, the maximum number will accrue gradually and fall away abruptly even though the spawning be more or less evenly distributed over a greater period, as appears to be the case in species migrating as fry. When the roung feed for a period or seatom before migrating this eflect will be obliterated by the superior ability of the larger of them to obtain food and hasten their growth.

That the migration of yearlings takes place in such manner that the average size of the migrants is about the same throughout the season is shown in the following table:

Lengtis of Migrating Yearling Sockeyes at Station 2, Naha River, 1904.

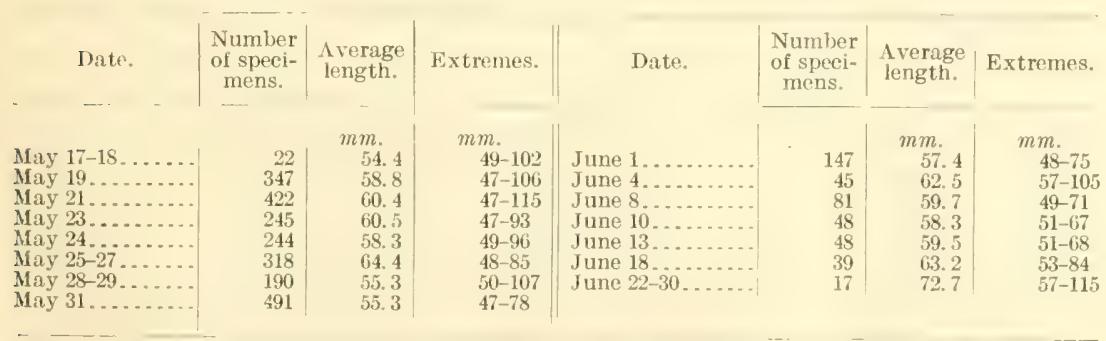

During the month occupied in the migratory movement there should have occurred a growth of some $4 \mathrm{~mm}$. in average length, but this in nowise appears, and it may be that the late-hatched 
vigorous fish whose superior feeding and digestive powers must have advaneed them beyoud less thrifty ardier-hatehed are amone the first. to reach salt water.

In the British Columbia work it was shown that the movement took place in the Thomplosen hetween the first of I tpril and the midelle of July, the run of fry being largest in April, with a temperature of $41^{\circ}$, whereas in the Fraser, with an April average of $36^{\circ}$, both fry and yearlings ran about one month later. 'The May temperatures of the two streams are about equal $-46^{\circ}$ for the 'Thompson and $45^{\circ}$ for the Fraser. In June they reached, respectively, $53^{\circ}$ and $51^{\circ}$. In the Wallowa River the movement apparently takes place in April; temperature unknown.

It would seem from these observations that migration begins when the water has reached a temperature of about $40^{\circ}$. At this time surface food. begins to be plentiful, hence the necessity of seeking new feeding grounds would appear to be less than it is earlier in the season. But before any definite statement can be made regarding food influences it will be necessary to become familiar with the crustacean life of the lakes. In the fall, at least some of the principal crustacean forms are multiplying, yelding an increasol food supply which might account for the continuance of crustacean feeders in the lakes. Surface food at that season decreases, hence the tarriers in the streams, as coho and king, must move on as winter approaches. That seareity of food has some influence might be supposed from the usual paucity of aliment in the stomachs of moving fish. Occasionally there will be found a stomach partially filled, but they seldom contain more than a small part of the quantity ordinarily found in examples taken from the resident individuals in any waters. It is probable that the fish take only what presents itself without any searching on their part.

Floods seem to have little influence on the movement of yearlings beyond the possible temperature influence. Fry are apparently swept out by high water, movement near the mouth of the streams inclining to be heaviest on falling water. No catch of yearlings was made in daylight in the Naha where the water is clear, and though the catch was uninterrupted during the night it appeared to be heaviest in the crening, daybreak serming again to aceentuate the movement slightly. In the muddy waters of the Fraser the catch was continuous through the day. The apparatus used, however, would not be effective in clear water in daylight, and its results can not be taken as a sure indication of the time of movement. That there is little movement in day in clear water is highly probable, since none has been directly observed.

The exact behavior of the large schools of yearlings has been fully described by Mr. Babrock in the report for Britiste Columbia, lons. They were observed to move down the lake in the afternoons, rumning 
headfirst from the quiet waters of the lake into the current of the outlet. Seton Lake is 17 miles in length and about 1 mile in width. In this body of water there can be no perceptible current setting down the lake, since the winds would produce more tide than eravity; temperatures, while higher at the head than at the foot, will exhibit no sensible gradual increase after a short distance from the inflow of the cold streams. Fet these schools, apparently guided by instinct alone, approach the outlet directly. Were not the same phenomenon exhibited hy migrating frr, as humpback, for examp.e, it might be supposed that the year's residence in the lake has familiarized them with its geography.

Upon reaching a pronounced riffle they "turn en masse and head upstream, cir ling and moving more or less rapidly in the more quiet stretches before venturing to àpproach the dam," i. e., the main fall. Their timidity in approathing swift water was notable. Only with the waning light would the first few allow the current to carry them down, the movement, or rather passivity, aradually becoming more and more general. It will be remarked that in heavy runs the average size is slightly smaller. This would seem to indieate that fishes not otherwise quite ready to migrate are drawn out by the general movement. The hesitancy to encounter swift water is noticeable in the adult as well. Spandling at Karluk remarked it as a prominent feature of the movement of spawners in the small streams, and schools often are noted standing in a swift current, seeming to hesitate to ascend or descend as the case may be. It would appear that this trait may have had no small influence in producing a resident form, though there is no reason to believe that the dwarf sockeyes as now known $(O$. nerka kennerly $i)$ are the product of the regular form, i. c., only tardy young that have failed to migrate with their fellows, and thereby remained to reach sexual maturity in fresh waters. Their distinctive size, varying with waters inhabited, and the small number of egos present in the ovary when yet little developed, mark them as at least a distinct race.

It has been reported ${ }^{a}$ that by the damming of streams for producing reservoirs to supply San Francisco and Oakland with water, the salmon then in those streams were landlocked. As a result they remained in the reservoirs and reprodured. Cltimately, by reason of the confinement and its effects, they became dwarfed, decreasing from their original weight of 12 to 14 pounds to less than 1 pound at maturity." The continual breeding of this species (O. tschawytscha), in confmement in fresh water secms to produce dwarfing, even with abundance of food. At the Trocadero Aquarium, where they have

a Report Commissioner of Fisheries, California, 1876-77, p. 5 and 6.

$b$ See report by W. N. Lockington, in Report Commissioner of Fisheries, California, 1878-79, p. 50. 
been bred in fresh water for several generations, the 4-year fish weigh from 2 to $4 \frac{1}{2}$ pounds. These are from the Sacramento Tish which average between 15 and 20 pounds. At the same time the number of eggs has diminished from a normal number of about 6,000 to only 1,300 to 1,400 .

These examples demonstrate a possible efleet of fresh-water residence. Dwarf sockeyes occur in such lakes as Alturas, Wallowa, Seton, Ozette, etc., in all of which fish may come and go at will. No other species of the genus breeds in lakes or exclusively in lake tributaries. It may be that the sockeye is in process of evolution from an anadromous form to a permanent fresh-water resident. Part of the yomong apparently possess the primal instinct to return to sea at once the first year, anothere and greater part hate changed to bereme oneyear residents, and the smallest part have lost the to-ocean instinct entirely and remain to reach maturty in the lakes. Experiments as to the action of artificially reared roung of the two races would be of the utmost interest and no little value to fish-culturists. The existenee of marine and fresh-water forms of the same species is well known in Atlantic Salmonidere, and as woll in other families. 'The cellect of change of habitat in the two forms respectively has in no instance been worked out, and remains for solution, one of the most interesting and important problems in ichthyology and fish-culture.

\section{KING SALMON.}

\section{AGE ANI) SEASON OH MIRTATION.}

The observations on the Sarranento liver have demonstrated that the king salmon young in that stream for the most part leave the fresh water as soon as they are able to swim and feed. All the spawning occurs in the upper parts of the river and its tributaries, yet fry with unabsorbed yolk were sometimes taken only a short distance above tidal influence. ${ }^{a}$ This same action was noted in the Karluk. On July 3 a trap which had been set overnight at the mouth of that river just above the hagom took 1,300 fry, nearly all of which were king: there were only 4 humploack and 7 sockeye fry among the examples saved. Is the collector did not differentiate species it is impossible to say whether 7 were all of the sockeye fry in the 1,300 , or whether that number was only the natural proportion among the 180-odd specimens saved. The humploack being of striking appearance, however, it is probable the 4 saved were the ent ire eateh of that haul. It should he stated that the haul also contained 5 sockeve yearlings, 25) ("oho fingerlings, a few st icklebacks, flounders, and young trout. No other sets of this trap were made; hence it is impossible to state

a Rutter, Natural history of the quinnat salmon. Bulletin U. S. Fish Commission, vol. $\mathrm{xxH}, 1902$, p. 92 . 
what period the run of king fry oceupied, but inasmuch as a few were taken in daylight, and the total mumber taken was so large, it would seem probable that the migration at that time was near its height. No fry of this species were taken in seine hauls made in the river May 22.

On the lower Sacramento the principal migration of the king fry oceurs in Mareh and April. Ife never forms on their breeding grounds, and they are free to travel as soon as they are able, which the temperature of the water and consequent time of hatching make possible at the above date. The adults reach the river in April, May, and June, and in August and September. They spawn in numbers from the middle of August to the end of September, and from the beginning of October until in December. The first eggs deposited begin to hateh about September, and fry begin to migrate about ()ctober, or even earlier, and continue throughout the winter, since no obstacle is offered by iec, and the fall and winter rains put the stream into the most favorable eondition. The run is practically over by April 1 on the lower river. From that date on it will be noted that the examples taken gradually increase in size, showing them to be in a manner summer residents. ${ }^{a}$

In the Karluk the adults first appear about the mouth of the river in May and continue in small numbers into August. They are known to spawn in the river below the lake late in August, or at approximately the same season as in California. The different time of migration of the fry is accounted for by the difierence in average water temperature. In the sacramento the eggs are deposited in water of a temperature of $56^{\circ}$ to $46^{\circ} \mathrm{F}$, the winter temperature rarely reaching as low as $40^{\circ}$. In the Karluk the lake surface in August varies between $40^{\circ}$ and $50^{\circ}$, or slightly above, and as the spawn of this species is deposited in the stream below the lake this may be taken to be the approximate temperature of the spawning beds. It is improbable that any great number enter the lake as adults to spawn in the lake tributaries. At an average temperature of $45^{\circ}$ (it is probably less) during August and September egges deposited in the latter part of August could not hateh before the middle of November. By this time it is probable that the temperature has dropped to freezing, and it is doubtful whether even the earliest eggs hatch before the advent of spring. The lake probably clears of ice and the water begins to warm up late in April or early in May. With the increased warmth, due to the long. periods of day in that latitude, the fry would have developed at about the date noted, namely, late in June and early in July. As there is little rain at that season, there would seem to be no cause for the downstream movement except age (development) and instinct. 
As in the Sacramento, it was found that a small number of young king salmon remain in the river until they reach the size of fingerlings. Five yearlings averaging $111 \mathrm{~mm}$. total length were taken in Karluk Lake June 5; 2 females slightly smaller, June 23 and 30;2 males, $115 \mathrm{~mm}$., were taken in an upstream trap at the mouth of the

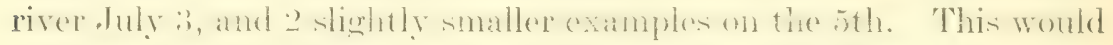
indicate that they were feeding in the river at this date. In a seine haul on the lagoon 4 males averaging $130 \mathrm{~mm}$. and 4 females averaging 13.5 mm. Were talien July 2t, in conpmuy with largenumbers of sockeye and king fry and a few coho and sockeye fingerlings (or yearling and small trout. It has not bou noted that these feeding fingerlings migrate in se heols, but liuter lats shown that in the Sareramento, with the growing searcity of food in the fall and the opportunity oflered hy fail fieshets, they gradually forsake their sunmer quarters.

The "summer residents" were also found in abundance in the Columbia River work of 1 w9.5. The altitude of these breeding waters and the proximity of snow tends to reduce the temperatures below

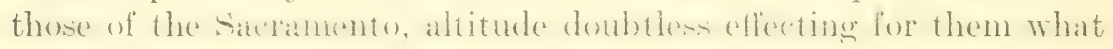
latitude does for the Karluk. The bottom temperatures given for Alturas Lake ${ }^{a}$ can not be relied on, owing to the character of the instrument with which they were taken. It is probable that the bottom temperature at 150 feet is little over $40^{\circ} \mathrm{F}$., as shown by later observations in Wallowa and other lakes. The falling air temperatures of the autumn must be closely followed by the water. The cireulation in these lakes must be comparatively small and the cooling of the waters rapid.

Dr. Evermann's researches show that the lake temperatures, and conseruenty these of the spaming waters, labll rapidly after August. Since the king salmon deposits its eggs late in August and early in september, it is likely that the early freezing of the water arrests the development of the fry, so that they can not arrive at the migrating stage until some time in the spring. But, in so far as the temperatures taken in Idaho are somewhat above the corresponding obserrations in Karluk Lake, it is probable that the downstrem migration of the main seluools would have heen eompleted before the arrival of the investigating party in July. The size and growth of the fingerling found exhibit a condition exart? analegous to that described by

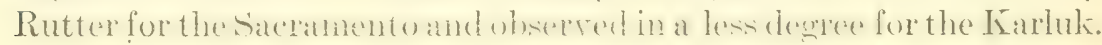

EFFEC'T OF CIINGE FROM FRESII 'TO SAL'T' W'TER.

Rutter demonstrated that the king salmon fry is unable to sustain immediate transfer from fresh water to sea water. In addition to his experineents on the Califomia salmon, he made at test at Karluk.

a Evermanu, Bulletin U. S. Fish Commission, vol. xvI, 1896, p. 157. 
August 2 about boo fry and lingerlinger were placed in a live-box 3 by 3 by 7 feet and towed from ihe river throngh the lagoon to the sea, a trip of 5 hours. About 50 died en route, 150 died during the following night, and all but 70 in the next 21 hours. These were probably all king salmon. The totals show that all under 2 inches died; 6 per cent of the fingerlings up to 21 inches lived; 94 per cent of the larger fingerlings lived. This result is singular enough when it is noted that the king salmon young migrating out of the river are but $1 \frac{5}{5}$ inches in average length. It is inconceivable that they remain in the fresh-water end of the lagoon until they have added 50 per cent to their size. Two-inch fish were taken by Figenmann in 1890 at Mare Island; 21-inch examples were taken by the writer in $189 \mathrm{~s}$ in San Pablo Bay in brackish water. There is every reason to believe that fungering of the latter leigth under natural conditions are perfectly able to endure a standard salinity. The fact that this species breeds only in rivers of considerable volume insures to the young the opportunity of making the transition with the necessary gradualness. In this they differ from the frequenters of short streams, the fry of which species are doubtless able to endure a sudden entry into salt water. ${ }^{a}$

The tendeney of the resident king fingerlings to advance upstream has been pointed out by Evermann in the report of the Columbia River inquiry. The same habit was noted by Rutter, and the presence of king salnon in the catrhes at Karluk Lake rerifies the earlier observations, showing that the lowation of the bresting ground is not closely indicated by the presence of the young:

HOOD.

The food of this species is almust wholly insects, in large part from the surface. The yearlings nentioned above, taken in Karluk Lake, contained omly insects, as did also the young taken at the mouth of the river; but the staken in the lagoon contained amphipods in arklition. These larege fish must be youlings. Their presence in the lake can be accounted for only on the assumption that the fry or fingerlings mierated into the lake the previous season, or that the yearlings ascend the stream in the spring and summer. Since their natural food would becone scarce early in the fall it would seem to be improbable that they would remain in the frosh water, whereas the length of the river and the ummaturalness of an instinct that would impel female yearlings to ascend it from salt water lay that supposition open to serious question. They remain to be acounted aberrant individuals

a Questions regarding the change from fresh to salt water, and vice versa, made by all the salmon, have been discussed in detail by Sumner (Bulletin U. S. Bureau of Fisheries, vol. xxv, 1905, p. 53-108) and by Greene (Bulletin U. S. Bureau of Fisheries, vol. xxIv, 1904, p. 429-456). 
that have obeyed meither the instinet to deseenel as fry nor that to seek the sea in self-preservation upon the approach of winter.

Migrating fry at the river mouth were largely empty, but a few contained insect remains. The small fingerlings taken in a seine haul in the lagoon also showed a purely insect diet. The lot taken by the trap at the river's mouth averaged about $42 \mathrm{~mm}$. (37-53); those seined in the lagoon averaged $47 \mathrm{~mm}$. (40-62), showing a growth of about $5 \mathrm{~mm}$. since reaching brackish water perhaps not over a month previously. It was noted that late in ofuly the number of these simall fish seen about the margins of Karluk I acoon had greatly decreased. indicating that the stay of the main boly in brackish water is short.

\section{COHO SALMON.}

\section{EARLIES'T MIGRA'TIONS.}

Is in case of the king salmoin, a considerable number of coho youner remain as summer residents in the streams of their birth or in the comnecting lakes; but the greater part seek the sea as soon as they become free-swimming. In the trap at station 2, on the Naha, the fingerlings and rearlings taken largely exceded the fry in number. Both were taken from the midlle of May until in. June-the migration period coinciding with that of the sorkeye. It is possible that this migration is in large part influenced by the sockeye movement. When yearlings of the latter species travel at the surface the cohos of similar size may be impelled, to some extent, to school with them; but the general absence of yearlings in the lakes early in the summer indicates that the spring migration is instinctive and general for the species.

The fry rach the swimming stage somewhat later in the season than the sockeye. The esces, though requiring a slighty shorter incubation period than those of the sockeye, are deposited much later in the fall. By means of a trap which was set in Steelhead Creek on Naha Bay in 190.1 the mieration was found to be heary as carly as May 19, water at $14^{\circ}$. On this date over 1,100 fry were taken, the net spanning the entire stream. This nun reached its maximum ten days later, when over 3,000 fry were taken in a sincle night. It continued, howerer, until sometime in July, when the temperature had reached $54^{\circ}$. In this ereek the humplack and the dog fry left in May, the eoho from the midille of May through Jume, and the steelhead in July. These dates are approximate for these species in the Loring district.

FOOD AND HABITS.

The fry taken in the trap during the time from May to July 9 showed no appreciable increase in size, the cateh average varying irregularly between 37 and $40 \mathrm{~mm}$. Of 600 measured, 85 per cent were 
between 36 and to -extrentes $3: 3$ and 13 mm. A few fingerlings, less than 1 per cent, were taken at the same time. The food at that time, in the few that contained any, was insects. 'The main movement was early in the evening, the lifting of the trap at $1.30 \mathrm{a} . \mathrm{m}$. and 9.30 a. m. of the same day showing a catch of 2,015 between dusk (about 10 p. m.) and 1.30 a. m. and 56 during the morning twilight.

In the Karluk in 190:3 the first specimens of colo fry were obtained May 22. At that time salmon fry and small fingerlings were said to be numerous in the little sloughs at the edge of grassy marshes where the current was slight. Over 1 , (f)o were taken in a single haul of the seine. Of the 42 examples preserved from this haul only 2 were cohos, about 38 mm. long, 1 with insect fool. (O) the 17 fingerlings saved from the same haul 15 were cohos, 12 males averaging $68 \mathrm{~mm}$. and 3 females averaging 52 mm., all feeding on insects and larva. It should be noted that the small fincerline sockeres taken in this haul containel crustaceans, some also insects and insort larra. while the 2 yearling sockeyes contained only insects and larva. Small fingerlings were taken in Karluk Lake July 27, 30, and 31, and as late as August 22. In all but 2 examples examined, which contained crustacea, the food was insects and insect larvæ.

coho young may be found in ahmont every browk of Alaska throughout the summer. They linger along the margins and in the pools, with no apparent seaward movement. As the adults penetrate all these small streams to spawn, the upstream movement of the young, if there be any, does not excite attention. They are resident in the lakes as well as in the tributary streams. With the fall rains these resiblents are swept out of the streams into the lakes or the sea in the same manner as the king.

In the summer of 1905 many coho fingerlings were taken in Yes Lake. August 22, 15, averaging 95 mm. in length (63-122 mm.), were taken in a night haul. Two of these (13 per cent) contained sticklebacks, one having eaten 12, all less than $20 \mathrm{~mm}$. in length; 66 per cent were feeding on flies, cte.; 13 per cent comtained beetles, and 26 per cent snails; 13 per cent had eaten carlis larva, and a like number other larva. August 24, 55 were taken in night hauls of a shore seine, average length 55.6 mm., extremes 5:3-130. Of these, 91 per cent contained winged insects, as flies and ants; 42 per cent beetles; 14 per cent mites, eggs, etc.; 7 per cent sticklebacks; 7 per cent snails; and 5 per cent caddis larvæ. September 10, 88 were secured in the same manner, average length $83 \mathrm{~mm}$., extremes 51-120. Of these, 44 per cent contained winged insects and the same number caddis larvæ, 20 per cent beetles, 11 per cent mites, etc., about 2 per cent sticklebacks, 5 per cent snails, and 7 per cent other larva than caddis. It will be noted that the average size of 
the latter lot is slightly smaller, but the deresease is not sufficient to indicate a movement of the larger individuals out of the lake. A more significant fact is the growing scarcity of surface food and greater amount of bottom material-the caddis found in their stomachs.

As early as April 6 (1903) coho yearlings of 145 to $165 \mathrm{~mm}$. were gilled at the Fortmann Ilatchery in Iteckman Lalie at the mouth of the river. They were attracted by the waste eggs thrown in the river.

May 17, 1903, 11 males taken at station 2 averaged $119 \mathrm{~mm}$., and 8 females 112; May 24 of the following year 12 males averaged 125 and 18 females 123. If these may be regarded as typical there appears to be a growth of ahout jo pere cent between September and May, or about twice that which from similar data was estimated for the sockeye. The yearling cohos taken in the Naha were found to eat the young salmon fry whenever taken with them in the nets. That they sometimes were able to prey upon them in a natural state was exidened by the presene of digested fry in some examples that were seined in Roosevelt Lagoon in May.

September 12, 1897, the writer seined a number of young cohos at the mouth of Klawak River. No other fisle caept sticklehackis were noted. Of the 71 cohos saved the 37 males averaged $85 \mathrm{~mm}$. in length $(50-125)$; the 34 females averaged a small fraction of a millimeter greater (47-135). At this time the hatchery was operating and sockeyes were spawning in the lake tributaries above. Many of these young cohos contained salmon eggs. A more common food was a large maggot, probably the blowfly larva from dead fish along the stream. One stomach eontained 2 leeches, and many of the smaller hard insects. Examples taken with a hook in brackisin water at the Klawak cannery wharf contained insects and a few beach crustaceans; 50 examples from the lake, (October 14, 1905, averaged about $75 \mathrm{~mm}$. These were taken with a dip net and do not give the average size of lake residents of that date. (See also record in salt water, p. 53.) Like the king fingerling the coho is readily taken with a hook, either with a fly or bait, salmon spawn being especially attractive in season. During the spawning seasem the coho in a few places may do some damage to the sockeye eggs. Large numbers are attracted to the scene of the hatchery work at Loring by the washings from the freshly spawned exgr. They were nowhere noted in any number on the natural beds.

As the result of the wide diversity of spawning regions, the coho may be said to possesis three morements seawad, first as fry second as fall fingerlings in the same manner as the king, and third as yearlings, lake winter residents leaving in the spring with the sockcyes. This 
may be true also of the king salmon, but it is not believed, from the observations on the Columbia, that the king spawns above the lakes ordinarily, hence only the wandering young would winter in them.

\section{DOG SALMON.}

The dog-salmon young, so far as known, all leave the fresh water as soon as they are able to swim. The records of the occurrence of larger individuals in streams have not been authentieated. The dog-salmon fingerlings reported in the rivers of Washington by (xilbert and Evermann ${ }^{\text {on }}$ on later examination were found to be cohos: A similar find by Davis ${ }^{b}$ likewise proved erroneous.

This species breeds in the Naha in too linited numbers topermit observations of value. Fry were taken in only two instances at station 2. I few were taken at station 1 the midclle of April, and again in Gibson and Emma creeks the midlle of May. They were found in abundance, however, rumning out of the creeks of Desp) (Moser) Bay, April 30, temperature $37^{\circ}$, many of them still! with remnants of yolk. A few were found in Steelhead Creek after May 7 and up to June 6 . In the main their fresh-water habit seems identical with that of the humpback.

Early in June, 1903, immense schools of small fingerling doe salmon were seen leaving the Karta River. Examples taken on the Sth of that month about the margins of the upper Kasaan Bay arerage about $40 \mathrm{~mm}$. They were feeding on insects. It was reported by the workmen building the Alaska Packers' Association trap at that point that shoals of these young could be seen at times well out in the bay, where they were pursued by larger fish, apparently Dolly Varden trout. The great number of adult dog salmon spawning in the Karta River makes this easily credible.

In the Karluk lagoon, 1903, fry and small fingerlings were ol)served in large numbers May 12-14. They lay close inshore by the spit, moving about in schools, but not going out with the tide. Some of these still contained yolk, others were feeding on insect larvæ, amphipods, and surface material. Slightly larer young were taken in the lagoon June 9-12, feeding on crustaceans and incects. June $1 \mathrm{~s}$ they were noted as abundant outside on Karluk Beach, 6 taken averaging $50 \mathrm{~mm}$. in length; they were feeding on insects, crustaceans, and small cottoids. July 24 neither $\log$ nor humpback young were present among the examples taken in a seine haul in the lagoon, all apparently having sought the sea. (See p. 52.)

$a$ Gilbert and Evermann, Bulletin U. S. Fish Commission, vol. xIv, 1894, p. 198.

$b$ Davis, Pacific Fisherman, vol. I, no. 4, May, 1902, p. 9.

$10731-07-4$ 


\section{HUMPBACK SALMON.}

The fry of the humplack salmon leave the fresh water with the breaking up of ice. In 1903 they were first taken $\Lambda$ pril 12 at station 1 on the Naha, but the number secured, 240, indicates that this was not the begimning of the run, though all the lakes were still covered with ice. The number migrating increased from this date to the end of the month, and they were found leaving the lagoon throughout May. During this time there was no increase in average size, the fry apparently leaving as rapidly as they at ained sufficient strength. They traveled almost wholly by night, the heaviest movement apparently being on the first of falling water after a rise. At these times the average size was slightly less than at others. On April 19 a trap set near station 3 took over 1,500 fry. There is but a very small spawn ng ground below Jordan Lake above the point where this net was set, and it is thought that the larger part of the run indicated by this catch had passed through Jordan Lake under the ice. The average size was a trifle greater than that of the fry taken at the same time at station 1, wholly because of fewer undersized.fish.

Very few humphack fry were seen at Karluk, a few were taken at the mouth of the river May 11, and again July 3, but at no time did they appear abundant. One example occurred in an experiment testing for endurance of salt water and was found to survive the test.

While the young humplacks are in fresh water, feeding is only incidental. A few have been found to contain remains of insects, larve, and crustacea. As with the dog salmon and coho, the descent from the small creeks in which many are hatehed makes it necessary that they be able to stand a quick change to salt water. In carrying a number from the trap in fresh water to the lower Naha Bay it could not be observed that immediate immersion in salt water caused them the least inconvenience.

\section{TROUT (STEELHEAD?) AND CHARR.}

The first trout fry appear in Steelhead Creek about July 1. On that date in 1903,255 were taken in the trap, and on the following day 295 . About the same number were present again in 1904, 28:3 being taken on July 9. While no further trials of the trap were made in 1903 the fry were noted to continue in the creek in large numbers until swept out by the fall rains about the middle of September. During this period their abundance was almost incredible when viewed with regard to the number of adults seen in the spawning season.

In the lower Karta River July 26, 1903, trout fry were very numerous. At this time the temperature was $64^{\circ}$ and the stream rery low. Along the sandy bars in places the receding of the water had left 
pools in wh ch large numbers of fry were imprisoned. The temperature in these pools was much higher than in the stream, and in many cases the water had evaporated, leaving the fry to die. All of them were swept out by the first rise.

At Karluk, August 29, 1903, in a small stream tributary to the small lake east of the main lake, Spaulding noted the occurrence of fry imprisoned in the same manner. From the date and place it is believed that these were trout fry. No examples were preserved. Small fingerlings and fry of trout may be seen during the late summer almost as widely distributed as the coho.

So far as observed the food of the trout fingerling is insects. 'The observations were made on . July $11 \mathrm{in}$ a pool about 6 to 18 inches deep at the foot of the fall in Flume Creek, where numbers of both trout and coho young fingerlings were resident for several weeks. The coho were schooling near the surface; the trout inclined rather to scatter and occupy the bottom. One trout was observed to take a position on a rock, from which it would dart for food to either side and forward for some 20 inches, returning each time to the same resting place. During the eight or ten minutes it was observed, it made over twenty trips, once attacking and driving away a brother fingerling that tried to take a place upstream and cut off the food supply. The trout rarely came to the surface, striking mostly at submerged drifting particles. Upon return to the pool two hours later the fingerling was found to be gone.

The fry of the charr oceur in very much smaller number. A slight migratory movement was noted in Steelhead (reck in 1904. Two were taken in the trap May 29,16 on June 5, and on the 13th 30 , the last observed. Their habit is to burrow in the gravel in the small streams. In these places their protective coloration and agility permit them readily to elude observation. No notes were made on the food of these young.

Fingerlings of all sizes of trout and charr were taken in the trap at various times, but no indication of any migratory movement appeared. Both species pass indifferently to and from salt water. The seaward movement of the fry is unquestionable, but individuals that remain in the streams after the fry period are doubtless governed only by convenience in obtaining protection and food. In the pools called Trout Ponds on Trail Creek only cutthroats and charrs were taken with a hook. These never exceeded a certain size, about 8 inches, though both male and female ripe cutthroats were taken Nay 30. In the brook below larger individuals were taken, a ripe female cut throat being secured April 25. No steelheads were noted in Trail Creek, but a few trout fry may be found there. In Steelhead Creek only rainbow and Dolly Varden trout are taken below the falls, but 
in the lake above the falls cotthroats are abundant. These falls are probably now impassable at all stages of water, and it is hardly to be believed that fry of the trout in the lakes help to account for the abundance of trout fry in the stream. It is to be observed that their numbers decrease toward the upper reaches, so that for some distance below the falls few are seen, and nome in the few yards of the stream between the lake and the head of the falls.

\section{SEA HABITS OF YOUNG SALMON.}

\section{NOTES AFFORDED BY COLLECTIONS AND RECORDS.}

THE SOCKEYE.

The sea habitat of the young sockeye so far has not been studied. The only observations available are the results of occasional and irregular seine hauls made by the dlbutross parties at various times, accompanied usually by no notes regarding exact locality or associated forms. These seant collections throw little light upon the sea habits or habital. The gear used was eapalbe only of taking examples in comparatively shallow water, close inshore, on smooth beaches. Iarger examples would stareely be taken under these conditions even if present in the same waters, and smaller fry would not be held by the web ordinarily used in the ressel's seines.

The smallest specimens in the collection are 8 examples averaging 41 mm., from Sumner Itarber, taken July 2, 1s96. This harbor is a small bay northeast of the town of Unalaska. It receives a small creek, the outlet of a lake. The fry were taken in company with coho fry and fingerlings. The sockeyes were feeding on crustacea, the cohos on both crustacea and insects. If they were taken in the bay, they were doubtless recent migrants from the lake. These sockeyes differ somewhat from the more southerly specimens in having shorter and less numerous gillrakers-about 10-17; in coloration they resemble some of the examples from Karluk, the parr marks being longer and nore bar-like than in these from southeast Naskat.

A number of fingerlings from iroud River, Bristol Bay, taken July 23, 1903, averaged about $41 \mathrm{~mm}$. in length. The stomachs.were filled with small crustaceans and insects. Wood River has little fall from the lake which it drains, and in spring tides is affected at fatr as the lake. No notes accompany the specimens, so they are of little biological significance. They seem to differ from the Southeast Naska examples of sinilar size in heing of les tapering outline and having a smaller eye. Six yearlings, average $98 \mathrm{~mm}$., are in the same lot, with the same food present in the stomachs. The main run from

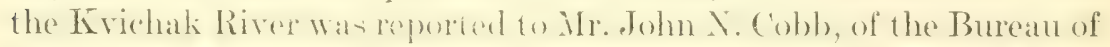
Fisheries, as acenring from the first to the midelle of . June, fish from 
$3 \frac{1}{2}$ to 4 inches in length. These are taken for eating by the Chinese at the cannery. Some are said to be pink-meated.

The next smallest examples in the salt-water collections are 12 from Alert Bay, British ('olumbia, taken June 5, 1895, probably from the beach near the cannery. With these are a number of small dog fingerlings of about $40 \mathrm{~mm}$. and possibly a few humplock. Many of the specimens are in poor condition and not positively identifiable. The sockeyes average $62 \mathrm{~mm}$. (53-68). Their food is all pelagic material, small adult copepods, ostracods and amphipods, crab larvæ, and a worm-like marine form-Sagitta. The other species were also feeding on crustacea.

From Nikolski, Bering Island (Komandorskis), there are 5 yearlings taken July 3, 1595; 2 males, 121 and $1.30 \mathrm{~mm}$., 3 females, 133 to $135 \mathrm{~mm}$.; all with amphipods in the stomachs.

From Kiska Island, June 7, 1894, 1 male, 196 mm., containing copepods, and 2 females, 230 and $245 \mathrm{~mm}$., with stomachs empty. These are said to have been taken in a small lake, but data for this are incomplete. They are apparently not dwarfs.

From Isanotski Straits, at the extremity of the Peninsula of Alaska, 5 examples were olotained July 1.5, 18.4: 3 males, 12.3 to 135 $\mathrm{mm}$., and 2 females, 132 and $143 \mathrm{~mm}$. The only stomach left in the specimens by the collector eontained small crustacea, sehizopods, and amphipods. These fishes were all infested with a parasitic roundworm occurring in masses in the region of the air-bladder. They are also noteworthy for the shortness of the gillrakers. These (on the right side) average less than $33 \mathrm{in}$ number, the longest equal to about the distance between 6 , or spumning $\delta$ interspares. The sperimens from Nikolski average 34, with a length equal to about $5 \frac{1}{2}$ interspaces. Those from Kiska run high, averaging 36 in the 3 examples at hand. Dundas Bay specimens, in a count of 12 somewhat smaller individuals, give an arerage number' of $: 3+$ + with arerage length a little less than 5 interspaces, whereas Karluk fish, in 10 examples taken June $\$$, 190:3, show an arerage number of $35+5$ and a length equal to nearly $9 \frac{1}{2}$ interspaces.

The examples from Dundas Bay were taken July 24, 1903, in a seine haul on the tide flats with mud and sand bottom. With them oceured dog and humpback fingerlings of about the same size, perhaps in the same sehool. The individuals saved are 6 males, average $80.6 \mathrm{~mm}$. (71-91), and 6 females, average 77.7 (73-85). They were feeding on crustaceans, insects, and insect larvæ.

At Uganuk young salmon are talien in large numbers in seine hauls for sand launces. Of 25 pounds of these small fishes taken in this manner June 15, 1903, 36 per cent were young salmon, mainly sockeyes, but in addition some cohos; 4 per cent were young herrings; the remaining 60 per cent were sand launces, or, as they are known 
locally, candlefish (Ammodytes). 'The sockeyes of this lot whose stomachs were examined contained crustaceans, a few with fragments of inseets also; several had small herring fry. Seventy-two males averaged s2. $1 \mathrm{~mm}$. in length (47-105); 70 fomales averaged $81.3 \mathrm{~mm}$. $(48-110)$.

It is a curious fact that in these collections, where there are large numbers of apparently regular-sized examples, usually the males are foume to average slightly the larger, whereas in cases of only a fow laree examples the females almost always exceed the males in size.

At Karluk young salmon are found ab!undantly in the waters in which seining for the camnery is carried on. It is said these yearlings sometimes rush throurh the seines in clouds, and even in the largemeshed seines numbers are drawn ashore with the arlults. From the catch on June 8, 1903, were saved 67 sockeyes, averaging. $181 \mathrm{~mm}$. (123-207). These were feeding on small crustacea; of 20 examined none had fry of any sort in the stomach. The distribution of food Was peculiar in that indiriduals were foeding almost exclusively on a griven form. For example, one was filled with ostracods, others had but few; some had almost mothing but copepods, others as exclusively amplipols; many, however, had such a mixture as would be expected. This seems to indicate that the crustaceans form schools to a certain extent, either in zones or otherwise, which enables the fish, acting as a tow-net, to obtain more or less nearly pure masses of a given form. Among the specimens saved from this haul other than sockeyes were only 2 cohos. One of these had eaten a young cottoid of $18 \mathrm{~mm}$. length.

On July 3 from a similar haul were saved 30 specimens; 12 males averaging $136 \mathrm{~mm}$. (122-156), and 18 females averaging $139 \mathrm{~mm}$. (125-164). Some of these were empty, most had been feeding on small crustaceants, several fontained in addition small coiled shells (pteropods), and 2 had small blemmies and sticklebacks in some number. One colno occurred in this lot.

July 24 young salmon were very abundant in Karluk Lagoon. A seine haul, with a 75 -foot seine, covering about 250 square yards, took over 2,000 salmon, 30 to $150 \mathrm{~mm}$. in length, and a few small trout and charrs. It is noteworthy that in this lot there seem to have bern no humphatek or dogs, whereas among specimens taken at the same time on the onter side of the spit, in the camery seine, no sork('yes weresaved. Whether this was a peculiarity of the distribution at that time or whether it arose from some other reason it is impossible to state. It is known that the collector did not elosely differcontiate the various speries. The young sockeyes taken in the lagoon varied from 30 to $145 \mathrm{~mm}$. in length. The smaller are doubtless from the hatchery, the yearlings may be from the lake; all were feeding on crustacea and inserets, the smaller fish more on insects 
and their larva, the larger on crustacea, mainly an amphipod. In several of each size were masses of intestinal worms.

It is stated that small salmon are seen in the seines throughout the raming scason, but mainly in the earlier part. It will be noted that the larger specimens were obtained in June, and that after July 3 no collection of sockeyes was made from the cannery seines. It may be that the continual hauling in time frightens them away; but it seems more reasonable to believe that with increasing age they move farther out from shore. The vast numbers observed in June must be the yearling migrants from the lake. As to what becomes of the fry of the same season after reaching salt water, there is no clue, and can be none until search is made foi them with small-meshed nets.

The only other specimens in the collection of interest in this connection are 2 males of $91 \mathrm{~mm}$. and 5 females 84 to $104 \mathrm{~mm}$., average o. 4 mm., taken in Karta Bay oJune 2ti, 1897. These contained mainly insects; some had alse crustacea, and one had a few young flatfish.

THE KING SALMON.

It is a signifieant faret that in the collections at hand there oceurs but one young king salmon taken in salt water. It would seem there should have been some in the Karluk Beach collections if the species is accustomed to tarry near its parent stream. They are sometimes taken in San Francisco Bay and the region outside the straits, but none of these examples have become part of the Bureau's collection. They have been reported also from the region of Killisnoo, Alaska. The example mentioned is a $215 \mathrm{~mm}$. male, which was taken with the rohos (see below) at the Loring cannery wharf August 2, 1904. As this was preserved for a coho, it is possible that others of the 45 mentioned below were of this species.

THE COHO.

The young coho in salt water is more easily observed than the other species. It readily takes the hook, and apparently is less timid than the others in approaching surface and shore. In 1904 45 were taken at the Loring cannery wharf August 2. They averaged $190 \mathrm{~mm}$. (158-226). On July 10 at the same place about 30 were taken. No measurements were made except of the largest, which was $138 \mathrm{~mm}$. On August 2, 1905, a scattered school came about the Albatross while anchored at the extreme head of Yes Bay; 26 , averaging $202 \mathrm{~mm}$. (152-237), were taken with a hook over the ship's side. Only a few, 6 or 8, would appear at once, and they took the hook baited with bits of meat, ete., very shyly in the perfectly clear water. Most of the stomachs contained oflal from the ship's messes; 5 contained fishes up to $65 \mathrm{~mm}$. in length, all that 
could be identified being sand launces; 2 cont ained young sticklebarks, one of them 10 individuals; 2 had isopods, and only 3 had taken insects from the surface. Another example taken later, a male of $265 \mathrm{~mm}$., contained 4 small herring.

At Karluk young cohos are occasionally taken in the cannery seines; two, $180 \mathrm{~mm}$. long, preserved from the eatch of June $\mathrm{S}$, con1 ained 2 speses of amphipods and one a young cottoid; one, $158 \mathrm{~mm}$., preserved from the seine July 3 , was an empty female; July 24 , another, $175 \mathrm{~mm}$. long, contained Ammodytes. As will be seen, these records indicate th: presence of very few young cohos about Karluk Beach.

The genern! collections of the Albatross afford the following data:

A number of cohos were taken at Karta Bay with larger sockeyes and smatler tow walmon on June 26, 1897. Of the specimens preserved 8 males average about $80 \mathrm{~mm}$. (56-100), and 14 females average nearly 100 mm. (s(0-140). They were feeding mainly on insects and crustacea.

At Thome Bay, July 5, of a number of small cohos together with a few dog salmon, seined probably at the mouth of the river, 24 males averaged about $55 \mathrm{~mm}$. and 50 females about $56 \mathrm{~mm}$., the high average of the latter being due to the presence of a few slightly larger indiviluabs (extremes, males t5-65 mm., females $45-78 \mathrm{~mm}$.). The stomachs cximined contained insects for the most part; a few had small crustaceans and 2 had flatfishes.

At Port Alexander, July 3, 1903, many young cohos were taken in the seine; 4 males and 2 females were preserved; average about $150 \mathrm{~mm}$. They were feeding on young herring and sand launces, also larval crabs and amphipods.

Of the specimens saved from Uganuk, June 15, 1903, 5 are males, averaging $138 \mathrm{~mm}$., and 8 females, $130 \mathrm{~mm}$. All but 3 , which were cmpty, were feeding on young herring, each containing from 1 to 5 individuals. (See p. 51-52.)

At Unalaska 6 examples, taken July 23, 1888, average $148 \mathrm{~mm}$., contained insects, crustaceans, grubs, and in one case a small fish like a salmon fry. One humpback fingerling was in this lot.

'Twelve examples, taken at Sumner IIarbor July 2, 1s96, a veraged about $60 \mathrm{~mm}$. and were feeding on insects and crustacea. They were in company with the smaller sockeyes. (See p. 50.)

Folated examples in the colleetion, not worthy of fuller notice, are: 1, Kilisut Harbor, July 1, 1903; 5, Tribune Bay, May 17, 1894; 3, Union Bay, British Columbia, June 22., 1903; 3, Cleveland Passage, July 1:;, 190:3; 1, Pavlof ILarbor, July 225, 190:3; 1, I Iumboldt Harbor, Shimagin Islands, July 31, 1sss; 3, New Morzhovoi, July 17, 1894, and 2, Kiska Island, June 7, 1894.

From the above data it is seen that the cohos remain for some months about the shores near the streams whence they issue. They 
may be found about the mouths of the streams in brackish water perhaps soon after their descent of the stream. It may be they remain about the streams for a time to accustom themselves to the salt water, but this is not evident in case of the fry. 'The sea-run examples are readily distinguished by the silvery appearance and usually by the greater depth of hody which follows habitual distension of the stomach. In some cases, while near in shore, insects appear to continue a staple article of diet, as in the fresh water. The cohos feed less on crustacea than the sockeyes, perlaps inhabiting slighter depths; correlated to this is the abundanre of small fishes found in their stomachs-sticklebacks in brackish water and herring and sand launces in more open regions.

From the catches at Naha and Yes bays it would seem that the cohos continue to school after reaching salt water. The results of the seine hauls indicate that the different species of salmon school together, or at least in the same waters.

\section{DOG AND HUMPBACK SALMON.}

On May 29, 1903, a small scheol of silmon, about 50) individuals, was seen along the shore about 1 mile below Naha Bay. Seven of these were secured-5 humpbacks $42 \mathrm{~mm}$., and $2 \mathrm{dog}$ slightly larger. The former were feeding on small crustacea and pteropods, the latter on crustacea and insect larvæ.

On July 1 and 2 a few dog salmon fingerlings were taken in the net at station 2. These may have been either fishes that had remained in Roosevelt Lagoon since early spring, or stragglers from the bay coming in on high tide. Ten were males, averaging $56 \mathrm{~mm}$., and 4 females, averaging 62. Those with food had been taking insects. (See also p. 47.)

At Karluk June 1s the fry of both dog and humpback salmon were abundant along the beach. Six preserved examples of the dog average about $50 \mathrm{~mm}$., and contained insects, crustaceans, and small cottoid fry. Thirteen humplacks saved average about $47 \mathrm{~mm}$; of the 6 larger ones examined 4 contained crustaceans, the other 2 nothing.

July 24 there were saved from the cannery seines 5 dog-salmon young, averaging $8: 3 \mathrm{~mm}$. (70-100), which contained a few insects and small fishes (blemies), but mainly crustaceans. Also 47 humpback young, averaging $77 \mathrm{~mm}$. (60-95), the main food in which was copepods, but in addition were found flies, insect larvæ, amphipods, and in a few cases small fry, probably Lumpenus, up to $18 \mathrm{~mm}$. in length; 1 stomach contained 22. of these. Only the following collections were made by the Albatross:

In Alert Bay, British Columbia, June 5, 1895, about $50 \mathrm{dog}$ salmon small fingerlings were taken, along with a number of small sockeyes; these averaged about $40 \mathrm{~mm}$. and contained only small crustacea. 
In Admiralty Inlet, Whidhy Istand, on June 30, 190(3, many young dog salmon were taken in a shore seine on gravel bottom. Of these 13 of each sex were preserved, the males averaging $99 \mathrm{~mm}$. (83-117), females, $98 \mathrm{~mm}$. (78-122). In none of the 9 examined were any fry found. They wore feeding wholly on planktom material, crustacea, principally amphipods, and Sagitte. 'They appear to have been schooling alone.

In Otter Bay, Pender Island, British Columbia, 11 dog salmon were preserved from the collection of May 31, 1895. These averaged a little over $70 \mathrm{~mm}$. and contained crustacea.

June 29, 1897, 4 dog salmon, 2 of each sex, averaging about $56 \mathrm{~mm}$, were taken at Loring, it is believed in a seine haul on the seining beach of Roosevelt Lagoon. They contained only insects. 'These specimens, considered in connection with those oltained at station 2, noted above, point toward a continuance of some of the young of the dog salmon in brackish water for a period and suggest the desirability of investigating such waters with suitable gear. $\Lambda$ haul was made in Roosevelt Lagoon on the night of October 1, 1905, but no salmon were obtained.

At Thorne Bay, July 5, 1897, many dog-salmon young were taken in seine hauls on the beach just below the river; 64 of the specinens are males, a veraging about $6.5 \mathrm{~mm}$. (42-52), and 84 are females about $2 \mathrm{~mm}$. longer (44-83). The food in those examined was crustacea, mainly ostracods. A few smaller ones taken in the river mouth were feeding on insects. In Karta Bay, June 26, 1897, dog, coho, and sorkeye young were taken in the same hauls. (Of the first, 19 males, about $60 \mathrm{~mm}$. average, and 10 females, about $5.3 \mathrm{mmn}$., were preserved. They were feeding mainly on insects and amphipouls; a few contained small flatfish, 1 being filled with them.

In Dundas Bay, July 24, 1903, many young salmon-sockeye, dog, and humpback-were seined on the tide flats. The specimens of dog salmon are 4 males, about $75 \mathrm{~mm}$., and 5 females, $82 \mathrm{~mm}$. long. They were feeding on crustacea; a few had eaten insects and larvæ in addition. The 3 humpback, 2 males and 1 female, average about $80 \mathrm{~mm}$.; food the same as the other species. The 3 species were apparently schooling and feeding together.

In Parlof Inarbor, July 25, 19013, the seine wats hauled at the mouth of a small stream in deep water, gravel beach. Many young dog salmon, a few cohos, sand launces, and other small fish were taken. 'The specimens of the first preserved are + mates, about 100 mm. long, and 7 females, slightly smaller. Their food was crustarea, except, in one instance, a few flies.

At New Morzhovoi, July 17, 1894, $34 \mathrm{dog}$ salmon young were preserved. These average about $80 \mathrm{~mm}$. in length. The stomachs contain crustacea and gastropods; only 1 had insects. These specimens show the peculiar segregation of food noted in some sockeyes at 
Karluk (p. 52); some had eaten almost exclusively large copepods, others ostracods, and yet others a peculiar Caprella-like form.

Four specimens from Isanotski Straits, July 15, 1894, show no peculiar features.

At Sucia Island, May 6, 1894, 3 humpbacks and 1 dog salmon were taken, the former $47 \mathrm{~mm}$. and the latter 54; food, crustacea.

At Metlakatla, July 10, 1903, 2 humpbacks were taken, $64 \mathrm{~mm}$. in length. One was empty, the other contained flies.

Single specimens of humpback fingerling are recorded from Kodiak, August 14, 18s8, and Unalaska, July 23 of the same year. The first, a female $113 \mathrm{~mm}$. long, contained small fry and a fow flies; the last, a male slightly larger, crustaceans.

\section{CONCLUSIONS FROM AVAILABLE DATA.}

From the above notes it may be concluded that many young sockeyes, after reaching salt water as yearlings early in the spring, remain, in company with other young sahnon, for a few months about the shores near the mouths of the streams from which they are derived; that during this time they feed prineipally upon the small crustaceans which are found from the surface to an unknown depth and, like the crustacean forms found in the lakes, have a diurnal movement from and to the surface. In tows made by the Albatross in the open ocean it has been found that many of these forms tend to be most abundant at the surface about dark, again decreasing in number within an hour or so. Whether the period repeats again at daylight was not tested. Surface tows in daylight made in Yes Bay and Behm Canal during July, August, and September, 1905, showed an almost entire absence of food material. At the same time it was found at depths of 20 to 75 fathoms and greater, the deeper the more abundant. It is known that this pelagie life is ultimately dependent upon the shore for food supply. The open sea far distant from land contains lit tle life, unless it be conveyed by currents originating near land. The narrow and deep channels of Southeast Alaska furnish a superior environment for plankton life; to the wholly free-swimming forms, such as copepods, ostracods, etc., there is added the innumerable progeny of the littoral forms, such as (rabs, worms, mollusks, and shore-spawning fishes.

\section{ABUNDANCE OF FOOD.}

As a test of the abundance of this salmon food material, during the summer of 1905 numerous hauls were made throughout Yes Bay and into Behm Canal. Yes Bay is a long, narrow inlet less than one-half mile in width and over 4 miles in length, the depth varying from 50 feet at the head to over 50 fathoms at the mouth. It receives several small creeks at the heal and the main stream from Yes Lake, about midway between the two extremities. During the summer 
months the surface temperatures vary between $55^{\circ}$ and $60^{\circ}$, the lower nearer the mouth. The surface densities depend almost wholly upon the precipitation. During ordinary weather the read of the bay, from the pushing up of the dense bottom layers of water by the tides, acquires about half the density of sea water; midway, on account of the volume from the main stream from Ies Lake, the density is reduced to about one-fourth that of sea water, increasing to one-third or more as the nouth of the bay is approached. During freshets the surface density is much reduced, the water becoming practically fresh at times. The bottom temperatures vary from about $50^{\circ}$ at the head in 50 feet of water to $44^{\circ}$ in 330 feet at the mouth, with corresponding densities of about 1.018-or nearly three-fourths the density of sea water-to 1.0235, or closely approxinating standard density. The tows exhibit a very scant population of food forms in the upper bay, with a gradual increase as the mouth is approached and a sudden rise upon entrance to the main channel outside. In the fresher waters jellyfishes predominate; with increasing density and lepth the crustaceans increase in number.

'This whole subject of the distribution of pelagic forms is of fundamental importance in the study of the sea habits of the salmon. With the pelagic forms, of course, must be considered also the shore forms, such, for instance, as the common amphipods (bearh lice), which may be found under stones at low water; perhaps, also, certain mollusks, etc. The factors of temperature, density, light, depth of bottom, proximity of shore, set and velocity of currents, influence of land drainage, etc., require to be carefully studied. As yet nothing has been attempted in Alaskan waters toward the solution of these problems.

It will be noted that the Karluk sockeyes taken in salt water in June are of gieater average size than those taken on subsequent dates at the same place. Further, that the average size of the Jume speeimens is about twice that of the migrants from the Taha taken only a few weeks earlier at Loring. If these Karluk sockeyes are accounted yearlings of average size for the locality, which have left the lake not arlier than April, nore likely in May, they either have increased very rapidly in size since reaching salt water or were much larger than Naha yearlings at the time of migration. But for the uniformity of size it would seem more probable that the specimens procured are the selected larger examples, the smaller escaping through the meshes of the seine. There is the possibility that these larger individuals were fry that reached salt water the previous summer, and that the absence of smaller specimens in the collections is due merely to the escape of the fry and fingerling migrants of the same season through the large meshes of the seine. That yearlings from Karluk Lake are larger than those of the sane age from the small lakes of Southeast Alaska may well be believed in view of 
the larger size of examples noted in Wallowa and Alturas lakes and the Fraser River.

The dog-salmon young, cited above, vary from a little over $40 \mathrm{~mm}$. to $120 \mathrm{~mm}$; the humplack show approximately the same figures. These are unquestionably of the fry that reached salt water in March and April just previous. The eatches date about three months later. This indicates an increase of about 100 per cent in that length of time, or about twice the rate of growth of the sockeves that remain in fresh water. In other words, the species (or individuals) that reach salt water as fry make about the same growth in the first three months that the lake residents (sockeyes) make in twelve. The comparison of fall catches of cohos and sockeyes in the lakes shows the former to exceed the latter greatly in size, but this is only a natural result of the coho's greater size from the fry stage to the adult. In the case of the humplack, however, the fry is scarcely larger than that of the sockeye, and the adult somewhat smaller. Its more rapid growth can be attributed only to the abundance of food in salt water and the nature of the fish. The sockeye young which were taken in salt water must be rearlings. Owing to the lateness of the migration of that species it is impossible for them to have attained such size in the time since they could have reached salt water as fry of that same season.

It will be seen that in general the four species of salmon are closely associated in sea habit. While small they remain much of the time close inshore, to some extent feeding on the insects that fall on the water or are carried down by the streams. The greater part of the food, however, is the various crustacean forms, though the small fry of marine species make up no small part, particularly of the coho's food. With increasing age the salmon doubtless move into deeper water. If the habit of preving on small fishes continues and grows with the increase of sizc, it would seem that the young salmon would be remarked in pursuit of the schools of young herring, sand launces, and such forms that abound in the bays and coast waters. No note of this has been recorded. Occasional catches of slightly larger fish are made from time to time, posibly fish of the second year. Such cohos are well known in Puget Sound, and a run of some small salmon was observed in Naha Bay during the winter of 1896-97. But unless such fish in large numbers approarhed the surface of some small body of water near a settlement, they would scarcely attract attention though the channels were teeming with them.

The salt-water habits of young trout and charrs are entirely unknown.

\section{RETURN OF ADULTS TO FRESH WATER.}

From the yearling stage to the adult little is known of any of the salmons, and nothing of the sockeye. There are reports of grown fish of that species taken in the winter in various places, as in the 
vieinity of Karluk and near Cnion Bay, Cleveland Peninsula; but the identifieation of these catches has not been authenticated. The only pertinent fact regarding their place of residence after leaving the vicinity of the parent streams, if they leave it, is that the presence of adult fish is first noted at the time when they are apparently rounding some point in their progress from more open water. Such places are Point Iligrins, at the entrance to Behm Canal; ('ape Chacon, at the lower end of (larenee Straits, and ()tter and sheringham points, on Juan de Fuca Straits. Karluk River is apparently approached directly from the open straits.

\section{APPROACH OF SCHOOLS.}

The presence of salmon can be noted only by their habit of leaping from the water as they approach the land. It is often possible by this means not only to recognize the presence of a school, but also to distinguish the species. In jumping, salmon do not leave the water with their ventral surface downward, as do fying-fishes. They always jump sidewise with one side at an acute angle to the water surface. Sockeyes seddom entirely clear the water, but let the tail drag for some distance, fall on the side, and then perhaps skim the water for a short space. They may make two or three successive jumps, apparently at random and in varying directions. Cohos usually leave the water entirely, falling back on the caudal peduncle held rigid with the fin directed upward. The tail may then drag through the water a short distance till the fish falls on its side and disappears. The humploacks jump very agilely and characteristically. 'They leap clear of the water, shaking the tails vigorously while in the air, sometimes turning completely with a corkscrew motion. On falling they strike on the side.

The cause of this jumping has been much discussed. It was noted that a school of kings feeding in Naha Bay in December, 1903, jumped in much the same manner as fish on the way to the spawning grounds, but apparently not so frequently, probably because of the small number of individuals under observation. The sockeye travels in large and compact schools when approaching the spawning regions, and the jumpiner should be easily ac'ounted for in the natural playfulness of crroups of animals or the struggle for preferred position. Stomachs of netted fish often contain salmon scales and teeth, the latter frequently the individual's own. But these are doubtless swallowed during the struggles in the net and not by reason of previous combats.

Under certain conditions the schools exhibit little tendeney to jump. In 1903 large numbers of sockeyes entered Karluk River without such announcement. Of rourse it is not known whether this species feeds in schools in salt water, or whether it is only the approach of sex maturity that impels the gathering into schools. From the 
arrangement of the gillrakers, and the few observations made on feeding fish, it may be surmined that the larger part of their nutriment is derived from pelagic crustacea and associated forms. They are known to feed at times on small fishes. In striking into a school of small fish from below they might be led to broach the surface. In towing for plankton food there would be no such occasion. No authentic observation of sockeyes in open ocean has been reported, but inasmuch as no search has been made for them the matter remains without evidence. It is probable that they do not jump in feeding, and thus they are unobsered up to the time they start for the spawning beds.

\section{FOOD AND FEEDING.}

'THE SOCKEYE.

It is reported that the liraser River schools, even before leaving Juan de Fuca Strait, have ceased to fered. In Southeast Maska it was found that a certain percentage of the earlier catches, even at the mouths of the rivers they were presumed to be entering, were still feeding. 'This is shown in the following table:

Food of Adult Sockeyes.

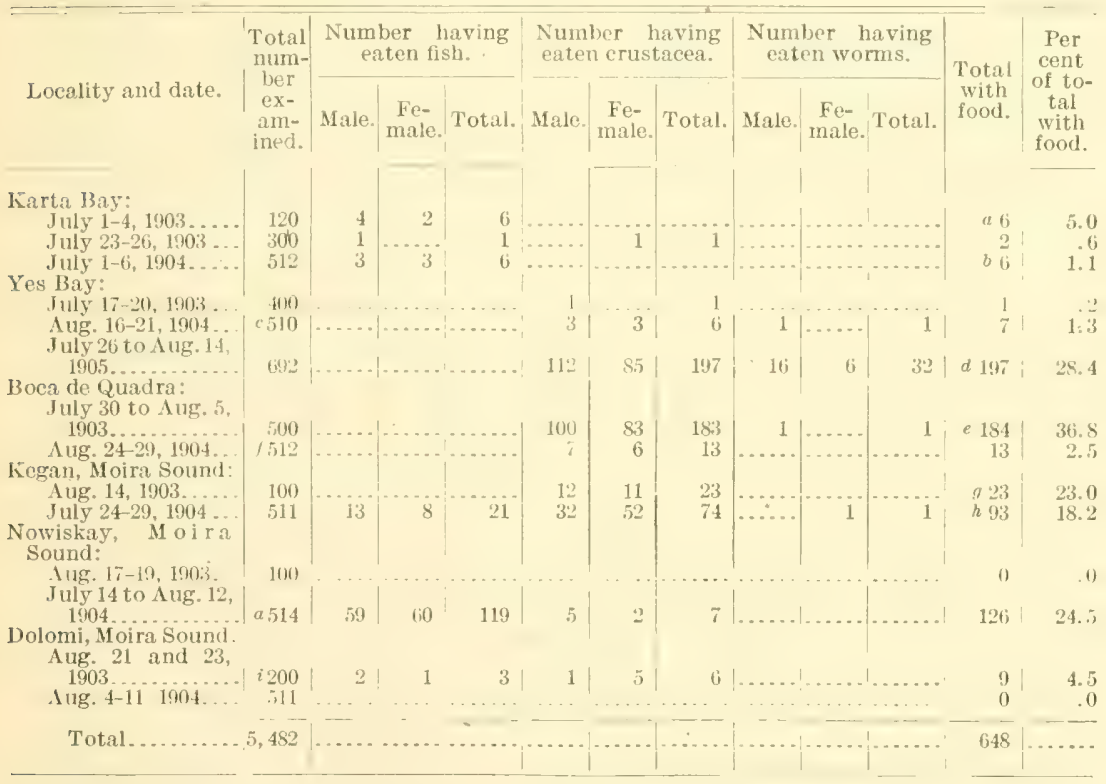

a Amodytes.

$b$ Ammodytes, except 1 with herring.

c In the last 111 examined, Aug. 20 and 21, the stomachs were all empty.

d Many stomachs with meduse, some with purple etenophores (?), which occur in about 50 fathoms of water in daylight.

$e$ Mostly larval crabs; also some small schizopod (?) forms.

$f$ In the 57 examined on Aug. 29, all stomachs empty.

9 Mostly a small shrimp-like form.

h Ammodytes, crustacea, mostly as above, but also crab larve. No food in stomachs of the 69 examined on July 24.

$i$ The 100 examined $\Lambda$ ug. 21 were empty. 
Stomachs of adult sockeves, as the tish are taken for commercial uses, are commonly empty. In many cases the shrinkage which follows the termination of feeding is pronounced, but wsually the upper limb is still lax, with only that degree of eontraction due to its emptiness, and the pyloric limb and coeca are still undiminished in size. On the other hand, schools are sometimes taken in which the shrinkage of all parts of the digestive tract is pronounced and the characteristic yellow slimy or curdy secretion fills the canal. The stomachs not infrequently contain scales, teeth, bits of regetable débris, etc., all of which is probably incident to the pursing of large numbers in the nets and consequent struggles of the fish. In many cases the esophaceal cavity is filled with a clear viscid liquid, which appears to be largely dissolved jellyfish.

In the examples examined at Yes Bay in 1905, undissolved portions of the common globular ctenophore frepuently oceurred. This same form was taken in great abundance in the surface and subsurface towings in the bay and in Behm Canal just off the bay. In addition, fragments were found of what seemed to be the larger ellipsoidal, purple ctenophore taken in towings in Behm Canal and elsewhere only in depths of 50 fathoms or more. It is not known whether this form rises at night, hence its presence indicates nothing as to the depth at which the salmon feeds. Nuch the greater part of the food observed is crustacean. In the examples from Boca de Quadra, 19(1)3, which have the highes percentage (36.s) cf foodcontaining individuals of any lot examined, the material is alnost wholly larval crabs, a few of the macruran forms also occurring. In Kecan examples the common crustacean form is a small macruran, though a few crab larva also were noted. In Yes Bay the most widely distributed form is a macruran, but crab larvæ are present in great quantity. Yes Bay salmon stomachs showed much the same agreation of forms that the tow net developed, which indicates that the food is taken by "towing."

Among the stomachs of sockeye salmon taken at Karta Bay, in Moira Sound, and at IIetta, were found some containing sand launces (immodytes alaseremus), in instances as high as 83 individuals in a single stomach. In these waters larese schools of wand launces sonewhat more than half grown are numerous during July and dugust. Schools of young herring occur earlier and during the same period, but in only one instance was a herring found in an adult sockeye stomach. In les Bay a small clam worm, identified by Dr. J. Perey Moore as ('allizona angtini (Kinberg) Apstein, was found in 32 stomachs, or over 4 per cent of those examined. Several of these worms were sometimes foumd in a sincle stomach, as if they had been assembled by selective feeding. A very few were noted at Boca de Quadra and at Kegan. These worms were taken only in the sub- 
surface towings at les Bay, but they probably came to the surface in the evening at that season.

It is remarked, in eneral, that the earlier runs of fish contain a higher percentage of feeding individuals than the later. Much depends also on the locality. It Dolomi practically all the fishing is done in a small bay almost at the river's mouth. It is improbable that the fish enter this bay in great numbers until ready to ascend the stream. Of 511 examples opened August 4 to 11, 1904, none contained food; many of these stomachs were shrunken, but some were still lax. Of 200 examined August 21 to 23, 1903, none of the first hundred contained food. These fish were of a distinctive type, more or less characteristic, long, slender, and dark in color. Of the second humbled, taken two days later, 9 were feeding on sand launces and crustaceans. These were brighter fish of a different typedeeper and more resembling the fish of other localities.

The fishing at Nowiskay was done by a single crew, hence ordinarily all or nearly all were taken near the mouth of the river. In 1904 , owing to the scarcity of fish, the crew sometimes hauled in the lower end of the arm, which may help to account for the larerer number of feeding fish taken that season. This same ciremistance has a bearing on the fish examined at les Bay in 1905. A greater part of the fishing was done in Behm (anal than in former seasons. The paucity of food material in the hays may sufliciently explain why the salmon do not approach the rivers until about ready to make the ascent.

Digestion in fishes is ordinarily (puite rapid. and for this reason we may be sure that food found has been recently ingested; but the fishing crews are out with the daylight, and our knowledge of the distribution of forms at that hour is too limited to permit any conclusions as to the depth at which salmon feed.

The presence of such large percentages of feeding fish might lead to the supposition that the fish were still on the natural feeding grounds and had not yet been made subject to the changed instincts of approaching maturity. This view is somewhat supported by the absence of food as reported in the large schools of the greater rivers at relatively earlier dates. On the other hand may be noted the fact that the Alaskan schools are much smaller, hence the opportunity to feed, if the instinct to do so still remains, is much better. $\mathrm{A}$ salmon stomach at any time, if empty for a period, becomes contracted and gives the appearance of being shrunken. This perhaps is due to the lack of blood in the tissues and the action of the contractile fibers. It is noted in migrating fingerlings as well as in adult fish. With the presence of food and excitation of secretion, blood will return to the tissues, the bulk of the ingested mass will stretch 10731-07-5 
the fibers, and the feeding appearance will return." It is probable that the sea habitat of salmon will be ultimately disclosed, if at all, by a study of their food and its distribution.

\section{KING SALMON.}

In recent years it has been learned that schools of king salmon feed in the channels and bays of Alaska during the winter. In 1903 they were first observed off Naha Bay late in December. Their presence was apparently due to the presence of a large shoal of herring, upon which they were feeding. The stomachs contained only herring, in one case 9 full-sized fish being counted in the stomach of a salmon that was still hungry enough to take the troll. Since the above date a valuable winter fishery for king salmon has been established. ${ }^{b}$ Previously they had been taken only at the time the herring were approaching their spawning beaches, about April and May, continuing to a greater or less extent throughout the summer in various regions. Their movement apparently depends entirely on that of the herring, which in turn may be supposed to be governed at other times than its spawning season by the abundance of its food; it is well known to be erratic in its appearance. The problems of the food supply of the herring in Alaska have not been considered.

The appearance of the salmon in Monterey Bay m the spring has been taken to be of the same character, i. e., a moving inshore with their food, which here consists of sardines, anchovies, smelts, and other small fishes, squid, and crustacea. ${ }^{c}$ It has been assumed incidentally that these fish are also on their way to the Sacramento to spawn. It does not appear that any careful study of their food, condition of maturity, or even species has been made.

The facility with which the king salmon is taken with a troll, and the eonsequent interest of anglers, may account for the fuller knowledge of the winter habits of this species. Of the other four species, only one takes a troll, namely, the coho.

THE COHO.

Little is known of the food of the adult coho. Its habit of approaching the rivers late, when almost sexually mature, and running at once into the stream, makes it difficult to study in this regard. The fond contents of the immature cohos taken in Puget Sound have not been reported. The adults are known to take the troll readily, which indicates that they feed on small fishes. ${ }^{d}$ Their early exhibition of this

$a$ Rutter, Bulletin U. S. Fish Commission, vol. XxII, 1902, p. 126.

$b$ See footnote $d$ below.

c Annual Report of the Department of Fisheries of Oregon for 1902, p. 69-78.

$d$ "Since 1904 during the winter fishing for king salmon numbers of cohos also have heen taken. Up to 1907 only troll lines have been used, but traps have been prepared for use during 1907-8." (Fassett.) 
instinct supports the inference, as does also the character of the mouth parts, teeth, and gillrakers. Two examples were seen at Karta Bay the first of August filled with sand launces; another contained a herring. One example, a female, taken at Quadra carly in August, was filled with crab larva, the same material upon which sockeyes were feeding at the time.

\section{HUMPBACK AND DOG SALMON.}

The humphack is ordinarily not feeding at the time it is taken in the cannery seines. Of a number examined at Karta Bay early in August, some of the males contained crustaceans and in one instance a sand launce; none of the females had food. At this time the males exceeded the females in number in the ratio of 50 to 15 . At Kegan early in August a few humpbacks were found containing the macruran from that locality. At Karluk, July 30, they were found to he feeding about equally on sand launces and crustacea.

The dog salmon has not been examined for feeding habits. Like the coho, it approaches the streams late, and as a rule the stomachs are then empty.

\section{RELATION OF FOOD SUPPLY TO NUMBER OF ADULT SALMON.}

The abundance of food has a direct relation to the number of adult salmon that may be produced. The propagation of countless myriads of fry can result only in their cannibalism if the supply of other food is lacking. The dependence of the different species of salmon upon other fishes is probably about in the same ratio as their averace size. The largest, the king, is largely dependent on the herring, sand launce, cod, etc., for its subsistence, as are, doubtless, also the coho and dog. The two smaller species, humplack and sockeye, are better adapted to live on the more minute life. They are not known to take a troll at any time. Their food is, at least largely, the food of the species which in turn support the king salmon. The interrelation has rearhed a nice adjustment in nature which, while not understood in detail, is known to exist. The extinction of the herring might lead to increased food supply for the growing sockere. At the same time it would deprive the dogfish and king salmon of their natural aliment and cause them to become a menace to the otherwise favored species. Only upon complete knowledge of the various elements of animal life can recommendations be safely made regarding more obvious matters. Empirical regulations may be successful, but rational legislation must ultimately rest upon results from the bolting-silk tow nets and the microscope. 


\section{AGE OF ADULT SALMON.}

The are of the sockeye at maturity is yet not absolutelydetermined. It is unnecessary to do more than refer to the four-year theory based on the quadremial increase in the Fraser River run. There seems to be sufleient reason for believing four years to be the usual term of life for the sockeye and the king salmon, but experiment has pretty conchusively shown that they may mature in less time or may be retarded beyond that term.

It is posibible that the humphack reaches maturity in lestime. The rapid errowth of the young and the biennial oceurrence of the species in Pueret Sound may be noted in support of this belief. The small size and irregular number in certain localities may be adduced also. A fish of a short growth-period would be more apt to show rapid fhuctuation in numbers than a form overlapping a variable series of years. At Yes Bay in 1903 many very large males occurred, in some cases reaching a weight of $11 \frac{1}{2}$ pounds. These were already much "humped" and advanced in sex maturity, whereas the main body of fish were still bright. Their occurrence was unusual and the size extraordinary. The fishermen believed them survivors of a previous season. The erilse form has not been noted amomg the humploacks or dogs. ${ }^{a}$ It has been reported for the coho by Mr. Patching, but not seen by the writer.

\section{SALMON-MARKING EXPEIIMENTS.}

Methods. - In an eflort to determine the exact age of maturity, fish have been variously marked. Is against the results thus obtained it has been asserted that any mutilations can be of no value, since the mutilated part will regenerate. There have been a number of trials of marks. Hubbard, experimenting in the Clackamas River, by removal of the adipose fin is supposed to have determined maturity to arrive in the king salmon at three, four, and five years - mainly at three. Richardson, at Karluk, by removing the dorsal fin in the same manner, arrived at four years as the average age of the sockeye. In Ausust, 190):3, 1,600 sorkeye fry, reared for the purpose at the fiortmann Iatchery from the 1902 ecros, were marked by excising both ventrals with fine curved scissors. The fry were released at a point in the Vaha just above Heckman Lake as soon as marked, at which time they were about 3 months old. In 1906 between 50 and 100 adult sockeyes with ventral fins missing were reported by the superintendent of the hatehery at les Lake from the spawniner beds there. Some had also the adipose fin removed; this mark in addition had been used on some of the fry mentioned above. At the Fort- 
mann Hatehery, where they were marked, only '2 of these fish were obtained in 1906. ${ }^{a}$ There is no doubt that these fish noted at the hatcheries were identical with the fry so marked. In careful measurements of over 7,000 sockeyes during two summers and casual inspection of many thousands during five seasons in Alaska, the writer has seen but one example of a salmon without rentrals, and in that case the fish was entirely without any indication that fins had ever begun to develop and was doubtless a monstrosity. The 2 samples sent in from Loring show the stubs of the fins just as would be expected from an amputation performed in the manner stated. This experiment, so far, supports the four-year theory.

In the spring of 1904 several thousand of the yearlings trapped at the head of Naha Bay were marked by the complete amputation of both dorsals. These fish were the same age as the fry mentioned above as marked the previous summer. There has been no record of the return of any of these latter. It is believed that the handling resulted in great loss and the percentage of survivors was too small to obtain notice even if, as is probable, the complete regeneration of the fin did not make the marking useless. I sinilar experiment at the Clackamas hatchery in the summer of 1904 has so far produced no result.

Mr. Rutter made several experiments in branding fingerlings, and reached the conclusion that it can be successfully done. Unfamiliarity with methods ordinarily used in branding led him first to try a five-pointed star. As was to be expected, when the fish survived the severe burn of the iron, which was seldom, the sear rapidly became formless by obliteration of the points. Subsequent experiments developed that a wire is a better instrument, the heat being applied wholly on fine lines, burning the skin but not injuring adjoining tissue. Any design with lines which do not cross, and which will not resemble in sharp angles or parallels the wounds of the teeth of predatory animals, will answer.

It is believed that if fin amputation is demonstrated as a feasible mark it should be performed on the small fingerlings. Fish under 2 inches are less susceptible to injury by handling. The fingerlings, after the formation of scales, are very easily injured, the scales parting from the skin upon the least touch. Their struggles when handled will almost infallibly produce abrasions. The experiment of ansesthetizing has not been made.

Regeneration of lost parts.-Regarding reproduction of lost parts, authorities differ. It was believed by Günther" that "the power of reproduction of lost parts in Teleosteous fishes is limited to the delicate terminations of the fin rays," etc.

a Seven more of these marked fish have been raported taken at the Fortmann Hatchery during the fall of 1907 up to September 29 .

$b$ Günther, Introduction to the study of fishes, p. 188. 
Jordan a reitorates essentially the same statement, and this belief was hede also by Weismann. Thomas IIunt Morgan hás by experiment demonstrated a sightly greater power of regeneration of lost extremities of fins than had previously been held to exist. After amputation of the distal portions of the caudal in the mudfish (Findulus heteroclitus) regeneration was distinetly marked in from seven to twelve days, indicating the ultimate reproduction of a perfect fin. In further experiments both the paired and median fins of this fish were found to possess the power of reproducing the distal portions after amputation. Similar regeneration in the caudal was demonstrated in the common scup (stenotomus chrysops) and the mackerel shad (Decapterus macarcllus). The presence of this fin-regenerative potency was also noted in the kingfish (Menticirrhus saratilis(?)), the goldfish (c'urassius auratus), a minnow (probably a Leuciscus), the stone cat (Noturus sp.), and others. In a spiny-rayed labroid (ctenolabrus) a pectoral fin cut off at the midille regenerated completely, and a pelvic (ventral) fin had partially regenerated when the fish was killed. In the toadfish (Opsemus tiu) the pectoral fins regenerated only very slowly. In none of these experiments is it stated that a fin was cut away closely at its base. There seems to be no evidence that Günther's original statement is incorrect. It was shown that in ordinary temperatures the beginning of regeneration is almost immediate where it does oceur; hence it is perfectly safe to assume that in the removal of the adipose dorsal in the salmon no regeneration occurs, since no beginning of a new growth is evident several months after its excision. Nor do these experiments militate against the results of the Loring experiment of entire amputation of the ventrals, cited above. It is probable that in very eold water the beginning of regeneration will be much delayed.

SALMON IN THE TROCADERO, A'T PARIS.

The most unassailable evidence of the are of kine salmon adults has been rendered by the aquarium of the Trocaderob, in France. It that institution king sulmon from egos obtained in California have been reared for some twenty-five years, generation after generation. It has been found that four years is the usual age, but that females may mature in three and in some cases not unt il five years. The males are found to be more precocious, some maturing in their second year. This precocity is noted in nature in the "errilse" of the sacramento and the "Aretic salmon" of the Alaskan sockeye. The occurrence of abnormally large fishes may be due to the delay of naturity until the fifth year. It was found at the aquarium that fish invariably died soon after completion of spawning.

$a$ Jordan, Guide to the study of fishes, vol. I, p. 150.

$b$ Bulletin de la Société Nationale d'Acclimatation de France, October, 1905. 
The New Zealand experiment in acclimatizing salmon indicates that both the sorkeye and the king reach maturity at the age of 4 years. These two species have been successfully transplanted to New Zealand waters, and runs of mature well-developed fish returned in 1906 to the respective streams in which they were placed. An aceount of the results will appear in the Proceedings of the American Fisheries Society for 1907 .

\section{FACTORS INFLUENCING RETURN TO FRESH WATER.}

\section{SEX INSTINCTS VERSUS CONDITION OF NUTRITION.}

The stimulus which it is assumed impels the salmon to seek again the fresh water is approaching maturity. Many known facts bring this assumption into question. The study of the Atlantic salmon by the Fishery Board for Scotland led to the conclusion that in that species the state of nutrition is the factor determining migration toward the river; that when the fish has accumulated the necessary supply of material it tends to return to its original habitat. In this conclusion it is assumed that the present sea-running race has been derived from a permanent freshwater-residing form. On the other hand it has been assumed for the Pacific salmon that at the time of separation of the early run to begin its travel into the stream, all of that school of salmon-both those that are to leave the sea at once and cease to feed and those that are to remain and continue to feedare equally well nourished and equally developed. It is known that heavy floods in the springtime bring heavy spring runs, and correspondingly poor fall rums, and it will be shown that the early arrivals in Nlaskan short streams are not so heavy in proportion to length as late arrivals. In all salmon the cessation of feeding upon or just previous to entering the fresh water brings a peculiar factor into the problem. When they start for the spawning beds the fish have two demands upon their supply of energy-producing stores, i. e., energy for the work of ascending the rivers, and material for the growth and development of the sex product-spawn and milt. In the ease of fish entering long rivers, such as the Columbia and Fraser, the early run enters with a slightly developed generative product to build up and the entire trip to the headwaters to perform. The late rum arrives with more fully developed sex organs and a much shorter journey to make.

Since no fish known to enter the streams fail to become sexually mature the same season, and since fish retained permanently in fresh water do not mature the sex product until they have reached the appropriate age ${ }^{a}$, it must still remain as the most reasonable con-

$a$ See Rutter, Bulletin U. S. Fish Commission, vol. xxII, 1902, p. 109. This can not be cited as an exception to the above statement, since the assumption that the precocious maturation is due to residence in fresh water has no other support, and, moreover, sea-run males are known to return as sexually mature grilse. 
chusion that the reproductive purpose is mainly instrumental in bringine them inte the streams. Correlated with this in determining the particular time of year for the entrance into fresh water are seasonal influences, temperature, density, currents, character of the river, etc. 'There may be sufficient explanation of the variation in time of rums in the proposition advanced by Moser, viz, that in streams where the rum is large both the precocious arrivals and the stracrelers are in sufficient number to be noted and recorded. But this can scarcely aceount for the distinctly double maxima noted in the runs of the Columbia and Sacramento rivers. The sockeye is said to "run" earliest in the Aleutian Islands, where it arrives in May. It is said to be found in the vicinity of Umnak Island all the year, in which case it must be feeding. In Bristol Bay the middle of . Jume is given as the time of arrival, but the run is usually small until in ofuly. At Karluk it is earlier, sometimes the first part of June, while in Southeast. Alaska the arrival is delaved in certain streams until the second week in July.

\section{'THE IOFFERENT RUNS.}

In large rivers different runs of salnon are noted-for example, in the Columbia and Sacramento the king salmon has two runs per vear, or two maxima; the early fish are supposed to travel to the headwaters of the various tributaries which they enter, the later run not to ascend so far. The April-June (?) arrivals spawn in July and August; the later fish spawn September to November. The reason for the separation is unknown. A well-marked division appears only in the Columbia and Sacramento. In the former river both kine and sockeye are so separated. The Karluk is said similarly to have two rums, one maximum about the last of Jume and one the first of August. but this was not true in 1903 when the river was under study. A double run might be supposed to bear some relation to the two migration periods of young, i. e., as fry or yearlings, but this is not borne out by the conditions in the Fraser, where such migrations are also known. In the Sacramento, the distance being short and the winters mild, the hatching periods and time of reaching salt water are distinct for each run. In the Columbia the elevation of the headwaters, with attendant low temperatures and distance which the fry must travel to reach the sea, may equalize the time of arrival at salt water.

The question whether an early hatched fry, the offspring of an early rum parent, will in turn become an early run adult is of much importance in fish-cultural problems. In the Sarramento hoth rums recoive attention at the propagatinestations. (On the ('olumbia it is mainly the late fish that are propacated, with what seems to be the result that early fish are becoming fewer. In the Fraser the early rum may escape by reason of the close seasons. In short dlaskan streams 
both early and late fish occupy the same grounds. The late comers thus destroy the early eggs to a considerable extent. Partly from this cause, perhaps, double runs are not well established; perhaps the fact that the volume of the streams is insufficient to carry the stimulus of the fresh water to the spring feeding ground permits the fish to remain together until all are induced by approaching maturity to direct their movement toward the coast.

Rutter found that of over $25,000,000$ artificially hatched fry placed in the Sacramento in $1897-98$, in addition to the product of natural reproduction, less than $1,000,000$ remained as summer residents. The following year the stations hatched about 17,000,000 from the two runs, with probably a greater natural production than the previous year. The fry passed the lower river between the middle of January and last of March, with maxima about six weeks separated (January 25-30 and March 8-13), or less than half the interval that separates the adult runs, if we assume that the fry taken in January at Walnut Grove were from the early run eggs, as we must by consideration of temperatures and the observed rate of travel. This does not bear out the opinion that runs remain distinct.

TEMPERATURE.

Adjacent streams may have different seasons, i. e., time of run. The variations in the small streams of the Loring district are of interest. The early streams are the Naha, with dates of June 14-26 for the first fishing; Karta Bay, June 13-26, and with these may be included Klawak, June 16-29. The late streams are Yes Bay, July 11-17; the Moira Sound group (Dolomi, Kegan, and Nowiskay), July 8-25; Quadra, July 13. The streams here listed as early streams all drain lake areas of considerable surface and of a character that would oceasion an early rise in temperature. The late streams have lakes of smaller total area or greater elevation and high surrounding ridges. The temperature data at hand are entirely too scant to demonstrate the difference suggested, but the few figures obtained seem to point to such a condition. They indicate that the streams are somewhat warmer than the surface in the adjacent salt water at the time of the run, i. e., that the fish leave the colder for warmer water.

June 30 a line of observations was carried from the Naha to Karta Bay. Off Loring the surface was $57^{\circ}$, density 1.0133 . With some variations the temperature reached its maximum, 59.5०, about midway across Behm Canal, with density lowered to 1.0112; from this point both temperature and density decreased until ofl Cape Camano, where the temperature had reached $54.5^{\circ}$ and the density had fallen to $1.0108-1.0110$. Off the cape a momentary rise in density1.0136 -occurred. Crossing Clarence Strait the temperature varied 
around $55^{\circ}$-density rising from 1.012 to 1.0216 -with which increased density the temperature fell again to $51^{\circ}$, and this, falliner in places to $50^{\circ}$, was carried. with a density of about 1.020 through Kasaan Bay into Karta Bay, when the density abruptly dropped to about 1.012 , with almost no change in temperature.

These figures show a general decrease in temperature corresponding to a rise in density. They show further that the surface density and temperature of Kasaan Bay is little affected by the fresh water from the Karta stream, whereas Behm Canal is markedly affected by its affluents. At this season sockeyes are rumning into both the colder waters of Karta Bay and the wamer waters of Naha Bay. The Karta Bay fish are reported to be seen first farther south along the west side of Clarence Strait. Inence they may never come in contact with the currents from Behm Canal.

Another series of observations was made July 30 and 31,1903 , from Kiegan stream to Dolomi via Old Johnson Stream opposite Kegan. In the Kegan Basin the temperature was $60^{\circ}$ and density 1.003 ; at the Kegan fish scow, anchored just outside the mouth of the stream, the temperature was about $53^{\circ}$ and density somewhat over 1.020 ; in the middle of Moira Sound, between the two streams, the temperature fell to $51^{\circ}$ and density rose to near 1.02.2. In Old Johnson Bay a temperature of $54^{\circ}$ and a density of over 1.020 were found. Passing down the sound, the temperature fell gradually, but varying, to $51^{\circ}$, with corresponding rise in density to near 1.022 . The inflow from North Arm (Nowiskay) could scarcely be noted. The lowest temperature was found off Point $A$ dams, $48^{\circ}$, with a density of over 1.022. The stream at Dolomi exhibited no influence outside the arm into which it flows. At the fish scow in the inner bay the temperature was $57^{\circ}$ and density 1.(0032. Five minutes' rum of the tug reached water of $52^{\circ} \mathrm{F}$. and density of over 1.020 .

If the fish travel on the flood tide, it must be necessary for them to approach these small streams very closely in order to feel the influence. The observations recorded above are all surface, where the greatest change would be made by the fresh water. It would seem scarcely possible to detect the river water outside the small basins or estuaries at a few feet below the surface.

It is not impossible that the incoming schools closely follow the coast line. For example, it has been stated" that sockeyes enter Uyak Bay, on the east side of IIarvester Island, pass to the south and east side of the bay, thence to the mouth of Larsen Bay, after which they follow the west side of the bay at some distance from the shore and pass out again into Shelikof Strait at the point where first seen. Since Uyak Bay contains no sockeye streams, such 
movements of a school, if they occur, can be regarded only as exploration either for food or spawning streams.

Other interesting temperature questions are raised by the sockeyes' selection for spawning of such streams as the one at Bartlett Bay. ${ }^{a}$ It may be postulated that streams with lakes at levels accessible to salmon possess a higher summer temperature than streams of similar volume without lakes. There is a class of streams, however, such as that at Bartlett Bay, where the lake outlet furnishes only a small part of the volume of the main stream. In the Bartlett Bay stream a temperature of $46^{\circ}$ at the mouth June 26 decreased to $39^{\circ}$ before the lake in which the sockeyes spawn was reached. The main volume of the stream is glacial water, and there is nothing at the mouth to intimate to human intelligence the existence of lakes and suitable spawning beds in its course. With even this temperature, however, the river was probally warmer than the surrounding salt water, in which ice was then drifting.

\section{CURRENTS.}

The influence of tide or current in salt water apparently varies, for reports are contradictory. The Fraser River sockeyes are said to travel on the flood, i. e., with the current. Salmon enter San Francisco Bay on the ebb. At Karluk they come in on the first of the ebb, or preferably on flood just before the current from the lagoon changes. In the Kvichak the last of the flood and the whole of the eblo are said to be the best fishing. By this they must approach on the flood and take the river on the ebb). It is also claimed that a southwest wind blows the fish inshore in Bristol Bay, whereas a northeast wind at Karluk is alleged to prevent their approach. The value of these observations regarding winds is lessened by the fact that certain winds prevent the operation of gear and perhaps influence the salmon not to expose their presence by jumping. It is believed that many fish, in 1903 estimated at some 2,000,000, reached Karluk Lake in this way by passing the bay and estuary unobserved. A similar instance was noted by Mr. Cobb on the Ugaguk in 1906, when an offshore wind had not prevented the schools from reaching the fishing ground. It seems probable that inshore winds, besides obscuring the presence of fish, will accelerate their movement by assisting the current shoreward, while an opposite wind will retard this.

In such streams as Dolomi it is inconceivable that a current influence can be felt beyond the small bay at its mouth. This may explain why only small fishes reach it, such small fishes perhaps traveling closer to the shore. On the other hand, none of the small salmon streams of that region can maintain the identity of their currents $a$ Moser, Bulletin U. S. Fish Commission, vol. xxi, 1901, p. 374. 
far beyond the receiving bays, and if currents are a prominent factor fish entering Behm Canal should all travel to the Unuk.

The influence of flood water on schools near a river's mouth may be due in part to an increased temperature of the water as well as to an augmented volume. It is well known that in dry seasons, when the streams are low, even though a sufficient depth for a practicable siscent may remain, schools tarry in the bays much longer than in rainy seasons. But as this is marked only in the case of small streams, the main factor must be the volume or quantity of water.

\section{ASCENT OF STREAMS.}

The speed of the salmons' ascent of rivers is perhaps modified by various conditions. In short streans of Southeast Alaska large fish are not noted in the rivers except while passing difficult falls. In the Naha they seem to make the distance from tide water to the lakes traveling at night, hence not observed. At Dorr Falls, on the Naha, humplacks which were constantly jumping at the fall throughout the day made no attempts at night. This lack of movement at night can not hold for waters of other character.

Observations on the Karluk indieated that about ten days wero consuned in making the ascent there, a rate of 2 to 3 miles per day, the main movement occurring after 4 o'clock p. $\mathrm{m}$.

Rutter estimated that the spring run of king salmon in the Sacramento ascend from the ocean to their spawning beds at the average rate of 10 miles per day. If some of this time is lost in the ebb and flow of tides in the bay, the rate in the river is in excess of this. The fall run, he deternined, ascended the river at the rate of 4 or 5 miles per day. Earlier observers supposed the fall fish to travel the faster." Sockeyes are reported to reach the Quesnel Dam, 500 miles up the liraser, about the middle of August; in 1906 the first arrived July 26. These are perhaps the fish entering the river in May and June, and if so they travel at a rate between 5 and 10 miles per day up a rapid river -ascending in that time to an altitude of 2,250 feet. The run continues at this point until September, perhaps inchuling a part of the heary July run at the mouth of the river. This would indicate that the rate of ascent is more nearly the higher figure, or that it is about equal to that of the early Sacramento fish. The variation between this movement and that in the Karluk is notable. Does it indicate any knowledge on the part of the fish as to the extent of the journey that is to be performed

No observations are recorded rexarding the movement of the coho or of the steelhead. The coho probably ascends rapidly when traveling for such points as the Wallowa and Baker Lake regions. The time occupied by schools of fish in the brackish water before entering

$a$ Report Commissioners of Fisheries, California, 1876-77, p. 10. 
the stream proper seems to vary with locality, species, and time of year. In some cases it is perhaps necessary that some time be so spent to inure the fish to the fresh water. Their natural timidity in approaching shallows has been mentioned above. This may be due to the exposure entailed or to recognized dangers in swift water. Adult sockeyes released at the foot of Seton Lake passed through the 17 or 18 miles of that body of water to its upper extremity in from eight and one-half to about eleven hours, presumably in daylight.

\section{INTERVAL BETWEEN ARRIVAL AND SPAWNING.}

The early arrivals of salmon spend some time in the region of the spawning beds before depositing any spawn. In the Naha the first sockeyes reach the lakes in June, but none spawn earlier than about the middle of August - after a lake residence of about six weeks. In the Karluk in 1903 the first sockeyes entered the lake about the middle of June; they continued to arrive in numbers until the latter part of July. They spawned during August. The first arrivals, as in the Naha, thus spent about six weeks in the lake and all remained at least four weeks before spawning. In the Fraser basin in 1905 the first fish reached Setun Lake the latter part of July, the run continuing until the latter part of september. The first exgs were spawned the first week of September, and spawning continued until late in October. This was approximately the same length of residence before spawning as in the Naha and the Karluk.

During the residence in the lakes it is improbable that the fish occupy the greater depths, since it has been shown that these are not suitable for fish life. In the evenings salmon may often be seen in numbers "finning," i. e., swimming leisurely at the surface in such manner as to expose the dorsal fin. The sockeye seldom jumps in lakes until about to approach the spawning bed, when there may be a slight demonstration of that habit. Ordinarily a lake may be filled with adult fish and no evidence of their presence noted by the observer.

The early king salmon also reach the beds some time before spawning. They reach the McCloud late in June or carly in .July, but do not spawn until the middle of August. In the Idaho investigation it was found that they reached the upper Salmon Valley the last half of July, the spawning oceurring approximately a month later. All sockeyes had entered Alturas Lake before July ?2() and spawned from the 23d until into September, the height of the season being about the last of August. The fish seem to have spent at least a month in the lake.

The late-running species-coho, humpback, and dog-arrive only a short time before maturity. 


\section{PARENT STREAMS.}

The election by salmon of certain streams as a spawning ground to the exclusion of others has long been noted in the case of the sockeye and king salmon. The choice on the part of the latter seems to be based mainly on the volume, only stragglers of this species entering the smaller streams like the Naha and Yes rivers. The larger streams, such as the Stikine and Unuk, carry large quantities of silt and thereby form extensive mud flats, which, with the drift carried on the strong currents, make fishing difficult. For this reason no adequate idea of the number of king salmon entering these streams has been obtained. The only small stream in the region near Loring which they are known to frequent, one tributary to Carroll Inlet, has not been examined. They are commonly thought to have in Alaska a predilection for streams of glacial origin, but all large rivers of this section have some glacial water.

The sockeye is recognized as exclusively a frequenter of streams with tributary lakes. The only suggestion adverse to this is a report by Mr. Fred Patching, superintendent of the Fortmann Hatchery, regarding a small stream in the vicinity of Wrangell, which Mr. Patching believes to have no lake water. The sockeyes are said to spawn in a somewhat expanded portion of the stream, but this expanse has not the character of a lake. As a converse proposition, not all lake outlets, even of apparently suitable character, attract the sockeye. The Anan stream, tributary to Bradfield Canal, seems to be perfectly adapted to all the sockere's requirements, but no recognized run enters it.

The dog salmon apparently recognizes some distinetions, though it is much more generally distributed than the two above-mentioned species. For example, comparatively few of this species enter the Naha or Yes rivers, whereas Karta River, on the opposite side of the strait, abounds with it.

The coho is probably less particular in its requirements. The fry were found, without exception, in every stream and brook examined; even a tiny secpage rill entering Naha Bay which would become dry with the first week of fair summer weather contained its little school of coho fry. That some streams are profitably fished for cohos, whereas others apparently as suitable are found not productive, is probably due mainly to the stream character, this in the one case being such as to promote the schooling of the fish at the mouth of the stream, while in the other a greater length of estuary or greater volume permits immediate ascent.

The humpback, like the coho, is found everywhere, and being exceedingly abundant is the more noticeable of the two.

The evidence in the question as to the existence of a homing instinct in the salmon is still lacking in many points. The exposition by 
H. S. Davis in the Pacific Fisherman (vol. I, no. 6, July, 1903, p. 6 and 7 ) summarizes the data as known up to that time. The facts advanced as evidence of the existence of such instinct are: (1) Distinctive and characteristic runs in various streams; (2) return of marked salmon to the stream in which liberated; (3) introduction into streams not previously frequented.

"INTRODUCTION INTO STREAMS NOT PREVIOUSLY FREQUENTED,"

On this subject little material data beyond Davis's citations is at hand. There is no report that runs have been established in either Papermill Creek or Chinook River. The release of fry in the Chinook River has been continuous since 1898, with no definite result. The presence of salmon in abundance in Tomales Bay has been reported, but seems to be only a result of their general abundance throughout the streams of northern California, and can not be credited to the plants in Papermill Creek. The introduction of Pacific salmon into streams of the eastern United States or of Europe seems not yet to have been successful. Until complete knowledge of the environmental requisites of the different species is obtained, the failure to establish them in these locations can not be accounted for:

The station at Baird, Cal., was opened in 1872 for the collection of salmon eggs for shipment to other streams, mainly in order to introduce the species into the waters of the Atlantic coast. The experiment was conducted on a scale unprecedented. The first plant was of about 6,000 fingerlings in the Susquehanna at Harrisburg in March, 1873. During the next three years over 640,000 were planted in the Great Lalies system, over 3,250,000 in Atlantic coast streans, over $1,000,000$ in tributaries of the Gulf of Mexico, principally in the Mississippi and its branches, and several hundred thousand were scattered about in the lakes of Minnesota. Colorado, and Utah. To these plants 18,250,000 fry were added in the next, five years. The last large plant was made in 1881, at which time the result had become less hopeful and the demand for more attention to the California home waters more urgent. This attempt at acclimatization was based entirely on the fact that the salmon is known to leave the cold ocean water and enter the warm rivers for spawning. The Sacramento rises to a temperature of over 80 and the Columbia reaches almost the same. Conditions appeared to be practically equivalent on the opposite coast, so far as temperature, volume, length, source, and nature of the rivers, the presence of food and enemies, etc., are concerned. But the attempt was an absolute failure.

The success recently attained in introducing both sockeyes and king salmon into the streams of New Zealand should supply valuable 
data not only on the life history of these species but especially on the physical requisites for practical work. The returning adults in these instances reached only the streams in which the fry had been placed, the two species not commingling. It is yet too early to draw positive conclusions regarding the relative influence of the two factors, natural suitability of the different streams, and a homing instinet.

That any given stream within the natural range of a species is not inhabited would seem to indicate its natural unsuitability. Whether the example of the Chinook River, where the king salmon once placed in the current of the river seems to find the locality at least endurable, can stand as a refutation remains yet to be proved. That it is not naturally populated by this species has been explained by the peculiar nature of its location and the general character of the stream and its bed. At least one of the principal guides directing the salnon to their spawning grounds seems to be the current. That the fish do not enter the Chinook River by choice is thought to be due to the lack of any sensible current from that stream reaching into the path followed by the schools in their movement from the ocean into the Columbia River. Temperatures have not been recorded. This same apparent influence of the current has been noted in many instances. For example, in the Columbia, salmon pass the Willanette during the summer season of flood, when the tributary river has become back water, but enter it before and after that season when the current is perceptible. At the Quesnel Dam in the Fraser system sockeyes died fighting the swift current of the race, while ignoring the feeble flow from the original fishway.

\section{"RETURN OF MARKED SALMON."}

The experiment in which the marked Naha fry subsequently appeared as adults at Yes Bay, as noted above, must be again mentioned. This result is a direct refutation of the homing theory. The relative numbers at Ies Bay and the Naha are the more remarkable for the reason that no Naha fish are taken except for breeding, hence almost all the individuals returning to that stream would be discovered, while at Ies Bay many may have been taken in the cannery seines and the record lost. In all experiments based on marking young fish by various mutilations the possibility of regeneration of the lost parts must be fully taken into consideration. In this experiment it is believed the fins were cut much closer than in the laboratory experiments.

\section{"DISTINCTIVE AND CHARACTERISTIC RUNS."}

Upon this point some more or less conclusive facts have been determined. The (rroup of streams fished by the Loring Cannery were studied in 190:3 and 1904, careful counts and measurements of a num- 
ber of fish from each locality being taken at the receiving scows in order to eliminate as far as possible any doubt regarding the region to which the fish belonged.

The localities are rather widely distributed. The most northerly and most distant from the ocean is Yes Bay, on the upper arm of Behm Canal. Opposite the mouth of this arm, and across Clarence Strait, is Karia Bay at the head of Kasaan Bay. The other localities are near the opening of Clarence Strait into Dixon Entrance; on the west side, Kegan and Nowiskay, tributary to Moira Sound, and Dolomi just above it; on the east side, Boca de Quadra, opening into Revillagigedo Channel; Tamgas, on Annette Island, about midway between Moira Sound and Boea de Quadra, and Port Chester, just above Tamgas, off Nichols Passage.

To make these data of decisive value it remains to be proved that fish taken in the receiving bay of a given stream are all destined, if not interfered with, to enter that stream for spawning. It has been sugrested that fish may congregate in a given bay for a time and, subsequently scattering, travel to distant streams to spawn. To test this, Rutter in 1903 tagged several hundred fish and released them in Karluk Bay or in the lagoon. But one of these was ever reported in another basin; most of them were retaken in the seines working in the bay at that time. If not taken the same day, they were seldom found, though oceasionally a straggler was discovered several days after its release, the latest nine days after tagging. While not at all definite, these results point to the probability that fow, if any, fish reach another river after appearing at the mouth of one. (see also p. 106.)

In some instances, in clossly adjacent basins, the fishermen in their eflort to meet the incoming schools reach the neut ral grounds between; for example, at les Bay some crews fish Behm Canal and so, perhaps, interrupt schools bound for the Unuk River; Moira Sound fishermen sometimes fish outside the respective arms. But this does not often oceur. In general, the figures from a given basin are believed to represent fairly well the fish traveling at the time for that particular stream.

Tariations in weights and masurements.- In this inquiry weights were taken on a small spring balance read to the nearest quarter pound. The lengths were taken with a steel tape, the fish lying on a flat table. The points chosen, with the view of later making comparative measurements on spawned fish, were the center of the eye and the extremity of the last caudal vertebra. The reading was made to the nearest half centimeter. The depth was taken at the front of the rayed dorsal by means of dividers, which were road from a scale to millimeters. As all the measurements with the exception of the Port Chester and Tamgas figures were made by the writer, the 10731-07-6 
personal factor is well guarded against. The exceptions mentioned are measurements made by Fassett after careful obśervation, and are believed to be closely comparable with the rest. The averages are given in the following table:

Table 2.-Average Weights and Measurements of Sockeye Salmon from DIFFERENT LOCALITIES.

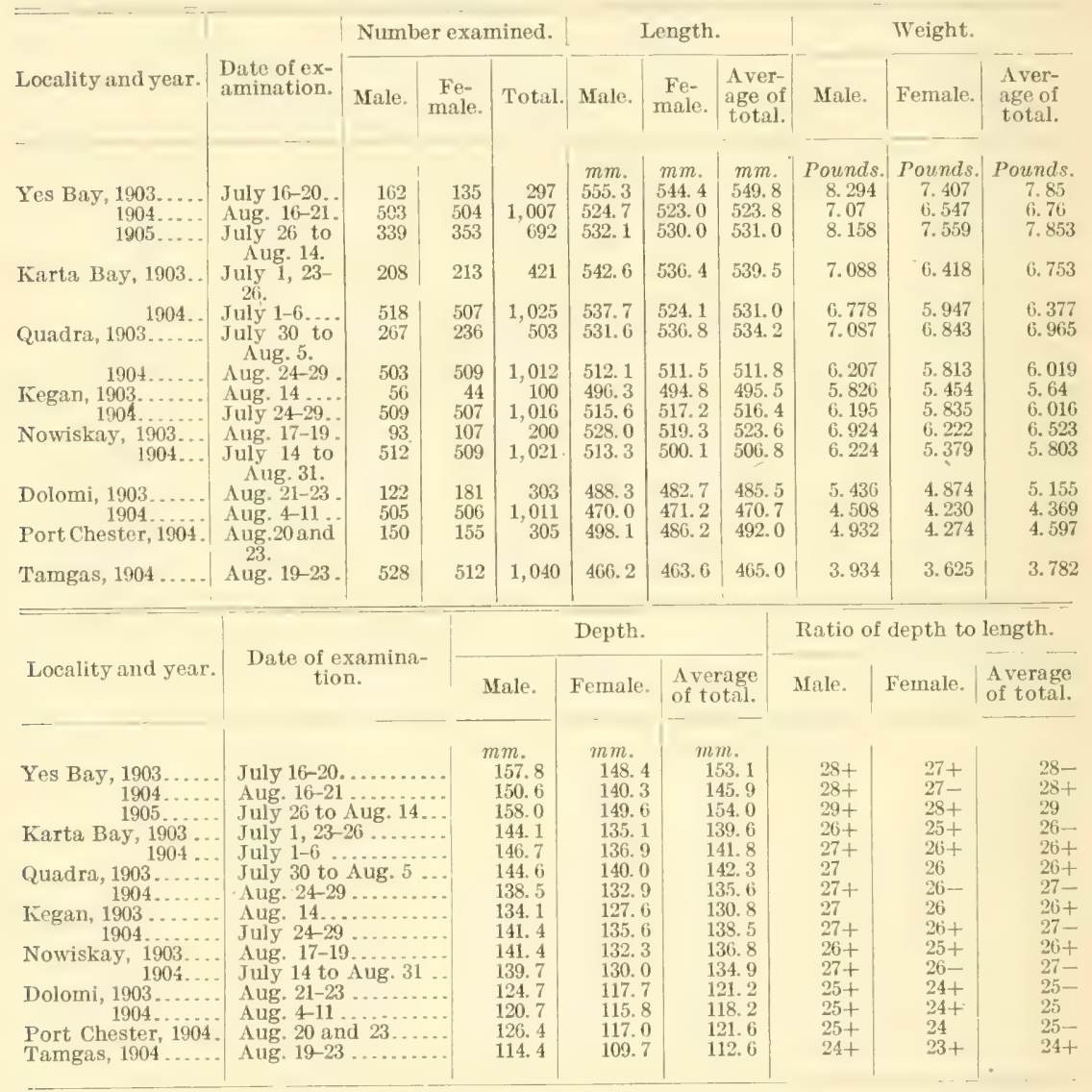

Of 100 sockeyes, equally divided as to sex, weighed at Karta Bay August 2, 1904, the males averaged 7 pounds and the females 6. Males were very slightly in excess in number at the time. 
Differences in Averages of the Sexes.

[Except where the minus sign appears, the figures represent excess in average of the males.]

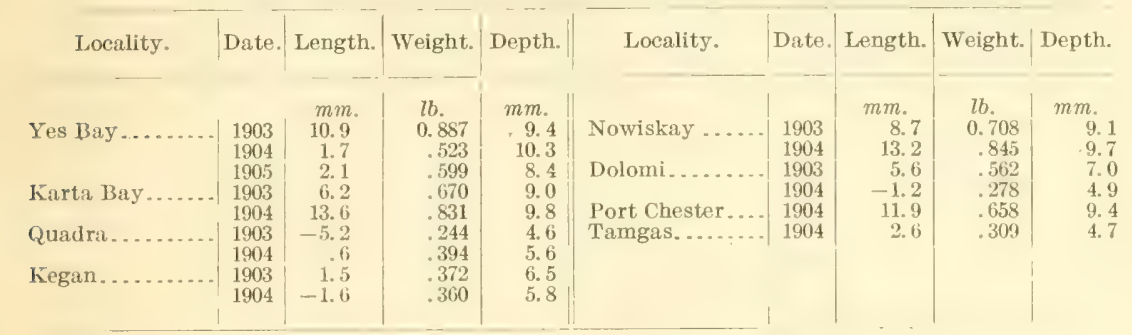

It will be noted that this table shows a smaller average size for the fish of 1904, except in one instance (Kegan); there the number obtained in 1903 was too small for accurate comparison.

The variation in depth between the two sexes seems to be practically constant, about 1 per cent of the measured length (which measurement is about three-fourths of the total length), or less than 1 per cent of the total length. The dates at which the examinations were made do not alter this ratio, showing that ordinarily there is no great increase of the depth in the male while still in salt water, and that variations of proportionate depth, as shown in the different localities, are not ąn effect of secondary sex changes. In all instances the males are heavier, although in a few cases slightly shorter than the females. This difference in weight varies from 3.6 per cent in the case of one lot of Quadra fish to over 15 per cent in the case of the Nowiskay fish of $190 \%$. The greater weight is attributable to the greater depth of the males, which exceeds the depth of the females by from 4 to over 7 per cent on the average. In these sex variations there seems to be no marked similarity in the two seasons for a given locality, the resemblance between different localities being greater in some cases than between different years in the same locality. In the few weights of Karta Bay fish taken in August, 1904, the difference in average of the two sexes is remarkable, amounting to over 16 per cent. This is probably due to the increased weight of the later running males. In all questions involving weight, analysis should be made to see what increase is due to mere increase of water in the tissues.

The only spawned sockeyes weighed were at the Fortmann Hatehery. These were apparently a somewhat different fish from those of other Iocalities, so no data as to the loss suffered during migration and spawning could be deduced. Seventy-two males averaging $539 \mathrm{~mm}$. (std.) in length (480-605) averaged 7.4 pounds in weight, or considerably heavier than fresh fish of the same length from other localities. The combined average of green fish of similar lengths 
from Yes and Karta bays is but 7.2 pounds. 'The 128 females measured show an average length (stl.) of $5.92 \mathrm{~mm}$. (465-570) and an average weight of 6 pounds. The combined average of Karta and Yes Bay females of similar length is about 6.3 pounds.

The figures obtained are hardly sufficient to determine the change, if any, incident to the varying periods of the run. Nowiskay is the only locality in which the measurements were carried through a considerable length of time. At this point, owing to the smallness of the early July run, the dates extended from July 14 to 22, and again to August 10, 12, and 31. In summing up these lots as July fish and August fish it is observed that the average length of the July fish is greater. Over 79 per cent of the whole number, 235, measured in July, are over $500 \mathrm{~mm}$. (std.) in length, whereas of the August fish, 277 in number, only 47 per cent exceed $500 \mathrm{~mm}$. The same fact is noticeable in the fish of Karta Bay in 1903. Of 55 measured the first of July nearly 62 per cent are $550 \mathrm{~mm}$. (std.) or over, whereas of 153 measured the latter part of that month only 45 per cent reach these lengths. These figures pertain only to the males, the females showing less variation. At other stations the daily distribution of sizes very closely resembles the totals, and a curve plotted for any one day would not vary materially from the curve for the total. ${ }^{a}$

The fish of Yes Bay are found to be the heaviest and also the deepest, those of Tamgans the lightest and relatively the most slender. The former are about twice the average weight of the latter, oneeighth lomger (total), and one-seventh greater in proportionate depth. These are comparatively widely separated localities; but the rariation between more adjacent regions, as Boca de Quadra and Tamgas, while less than in the case of Yes Bay and Tamgas, is still marked. A yet more interesting instance is seen in the streams of Mloira Sound and Dolomi.

The average weight of fish from Nowiskay is nearly one-third greater than that of the Dolomi fish, and they are nearly one-sixth longer and of somewhat greater proportionate depth. These basins are immediately adjacent and this difference is always well recognized by the fishermen. It indicates one of three things: That the fish exereise some selective instinct in choosing their spawning stream; that they are practically limited in their feeding activity to a radius of less than 10 miles, or that the currents are such that the product of these two streams remain as separate schools in different areas.

a At Karluk it is reported (Alexander, ms.) that the earliest-run sockeyes are smallest, averaging 16 to the case when canned. As the season advances the size increases until 11 or $11 \frac{1}{2}$ make a case; but again by the middle or latter part of August the size falls to about that of the beginning. This may hold in other localities, the earliest of the run passing unobserved by reason of the small number. 


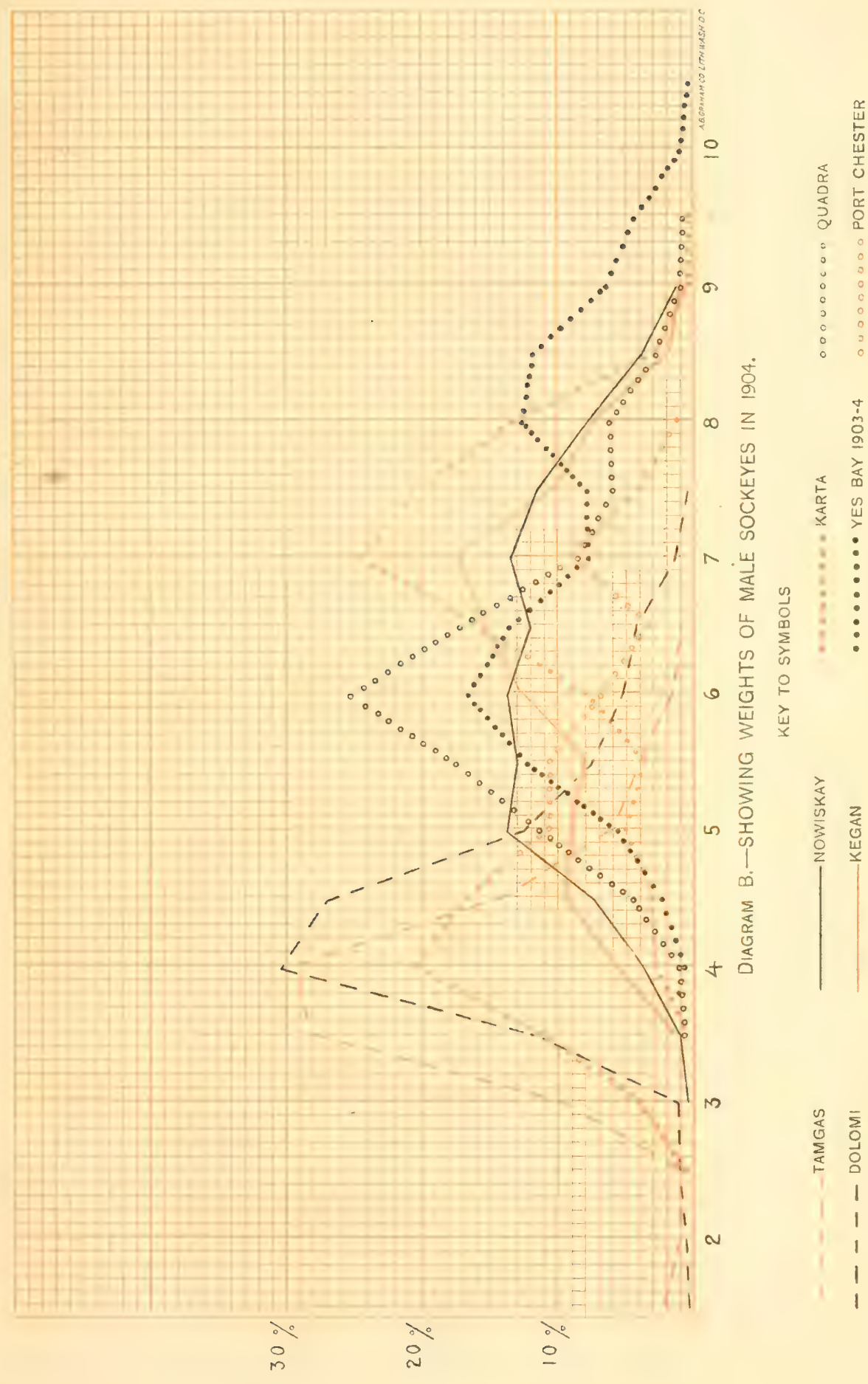



In table 3 are shown for the males the percentages in which each weight (to the nearest half pound) was found in the respective lots. In diagram B are plotted the curves for each lot for 1904, the weights being marked off in the horizontal axis and the number of examples of each weight, as a percentage of the whole number weighed at at given locality, indicated on the verticals.

Table 3.-Weights of Male Socheyes, Shown as Percentages of the Total Number of Examples Examined from Each locality.

\begin{tabular}{|c|c|c|c|c|c|c|c|c|c|c|c|c|c|c|c|}
\hline \multirow{2}{*}{ Weight. } & \multirow{2}{*}{$\begin{array}{c}\text { Tam- } \\
\text { gas. } \\
1901\end{array}$} & \multicolumn{2}{|c|}{ Dolomi. } & \multirow{2}{*}{\begin{tabular}{|c|}
$\begin{array}{c}\text { Port } \\
\text { Ches- } \\
\text { ter. }\end{array} \mid$ \\
1904
\end{tabular}} & \multicolumn{2}{|c|}{$\begin{array}{c}\text { Nowis- } \\
\text { kay. }\end{array}$} & \multicolumn{2}{|c|}{ liegan. } & \multicolumn{2}{|c|}{ Quadra. } & \multicolumn{2}{|c|}{$\begin{array}{l}\text { Karta } \\
\text { Bay. }\end{array}$} & \multicolumn{3}{|c|}{ Yes Bay. } \\
\hline & & 1904 & 1503 & & 1904 & 1903 & 1904 & 1903 & 1904 & 1903 & 1904 & 1903 & 1904 & 1903 & 1905 \\
\hline 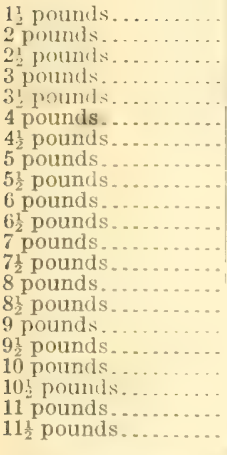 & $\begin{array}{r}3.1 \\
1.0 \\
1.1 \\
4.4 \\
24.3 \\
29.4 \\
14.0 \\
6.0 \\
4.0 \\
1.0 \\
1.0 \\
.4 \\
.2 \\
\ldots . .\end{array}$ & $\begin{array}{r}0.2 \\
.4 \\
1.0 \\
1.0 \\
11.4 \\
30.2 \\
26.8 \\
12.4 \\
7.2 \\
5.0 \\
4.0 \\
1.2 \\
.2 \\
\ldots . .\end{array}$ & $\begin{array}{r}\ldots . \\
\ldots . \\
0.8 \\
10.7 \\
8.2 \\
32.2 \\
12.4 \\
14.8 \\
5.0 \\
7.4 \\
6.6 \\
.8\end{array}$ & \begin{tabular}{r|}
$\mid 0.0$ \\
4.0 \\
11.3 \\
20.6 \\
16.6 \\
10.6 \\
10.6 \\
6.6 \\
3.3 \\
9.0 \\
4.0 \\
1.1
\end{tabular} & $\begin{array}{r}0.2 \\
.8 \\
3.5 \\
7.3 \\
13.5 \\
12.7 \\
13.5 \\
11.7 \\
13.3 \\
11.3 \\
7.4 \\
3.5 \\
1.0\end{array}$ & $\begin{array}{r}2.1 \\
7.6 \\
4.3 \\
8.6 \\
15.2 \\
20.4 \\
20.4 \\
18.3 \\
2.1 \\
1.0\end{array}$ & $\begin{array}{r}1.5 \\
5.7 \\
9.6 \\
9.0 \\
8.0 \\
12.7 \\
15.5 \\
17.4 \\
10.2 \\
7.3 \\
1.8 \\
1.0\end{array}$ & $\begin{array}{r}5.4 \\
5.4 \\
10.8 \\
28.5 \\
25.0 \\
12.5 \\
5.4 \\
5.4 \\
\ldots \ldots \\
\ldots \ldots \\
1 . . \\
\ldots \ldots\end{array}$ & \begin{tabular}{|r|}
11.4 \\
1.0 \\
4.2 \\
11.0 \\
17.4 \\
25.6 \\
17.0 \\
8.2 \\
5.8 \\
6.0 \\
2.6 \\
.6 \\
.6 \\
.2
\end{tabular} & \begin{tabular}{r}
1.4 \\
$\ldots .$. \\
\hdashline 1.6 \\
6.0 \\
20.8 \\
13.2 \\
14.4 \\
10.9 \\
18.5 \\
4.5 \\
.1 .1 \\
3.5 \\
.7
\end{tabular} & $\begin{array}{r}11.4 \\
2.9 \\
3.1 \\
5.2 \\
3.7 \\
8.0 \\
16.0 \\
24.4 \\
22.0 \\
13.0 \\
2.7 \\
.6 \\
.6\end{array}$ & $\begin{array}{r}1.0 \\
1.9 \\
5.8 \\
5.8 \\
9.1 \\
9.6 \\
17.7 \\
18.2 \\
17.0 \\
6.3 \\
4.3 \\
2.4 \\
. .5\end{array} \mid$ & \begin{tabular}{|r|}
0.6 \\
2.2 \\
5.4 \\
12.0 \\
16.6 \\
13.2 \\
7.6 \\
7.6 \\
12.4 \\
11.4 \\
6.2 \\
4.2 \\
.9 \\
.2 \\
$\ldots \ldots$ \\
$\ldots .$.
\end{tabular} & $\begin{array}{r}0.6 \\
2.4 \\
1.8 \\
1.8 \\
7.3 \\
11.5 \\
25.4 \\
18.2 \\
15.9 \\
9.1 \\
4.2 \\
.6 \\
.6 \\
.6\end{array}$ & $\begin{array}{r}0.3 \\
.6 \\
.6 \\
.9 \\
2.0 \\
4.7 \\
5.0 \\
11.7 \\
15.3 \\
18.2 \\
14.8 \\
13.9 \\
5.0 \\
3.2 \\
.3 \\
.3\end{array}$ \\
\hline $\begin{array}{l}\text { No. of specimens. } \\
\text { Average weight, los. }\end{array}$ & $\begin{array}{l}5.24 \\
3.9\end{array}$ & $\begin{array}{l}.50 .5 \\
4.5\end{array}$ & $\frac{1.21}{5.4}$ & $\begin{array}{l}1.50 \\
4.9\end{array}$ & $\begin{array}{l}512 \\
11.2+\end{array}$ & $\begin{array}{r}9.3 \\
6.9\end{array}$ & $\begin{array}{l}509 \\
6.2-\end{array}$ & 5.5 & $\begin{array}{r}503 \\
6.2+.\end{array}$ & $\frac{26 i 4}{7.1}$ & $\begin{array}{l}518 \\
\text { (i. } 8-\end{array}$ & $\begin{array}{l}207 \\
7.1\end{array}$ & $\begin{array}{l}501 \\
7.0\end{array}$ & $\begin{array}{ll}10 i i \\
\therefore .3\end{array}$ & $\begin{array}{l}3389 \\
\$ .2\end{array}$ \\
\hline
\end{tabular}

In table 4 are shown for the males the various lengths tabulated by percentages of the number of fish in the lots measured, in the same manner as in table 3 to show the weights. In diagram $\mathbf{C}$ are plotted the curves for each lot measured in 1904; in diagram $D$ the curves for the lots of 1903 and 1905 . Table $4 \mathrm{a}$ shows in the same manner the lengths of female sockeyes. 
Table 4.--Lengths of Male Socheyes, Shown as Percentages of the Total Number of Examples Examined in Each Locality.

\begin{tabular}{|c|c|c|c|c|c|c|c|c|c|c|c|c|c|c|c|}
\hline \multirow{2}{*}{ Standard lengths. } & $\begin{array}{l}\text { Tam- } \\
\text { gas. }\end{array}$ & \multicolumn{2}{|c|}{ Dolomi. } & Port & \multicolumn{2}{|c|}{$\begin{array}{l}\text { Nowis- } \\
\text { kay. }\end{array}$} & \multicolumn{2}{|c|}{ Quadra. } & \multicolumn{2}{|c|}{ Kegan. } & \multicolumn{3}{|c|}{ Yes Bay. } & \multicolumn{2}{|c|}{$\begin{array}{l}\text { Karta } \\
\text { Bay. }\end{array}$} \\
\hline & 1904 & $1 ! n+4$ & 1963 & 1904 & 1904 & 1903 & 1304 & $1: 03$ & $1 ! 904$ & $1 ! 103$ & 1904 & 1903 & 1905 & 1901 & 1903 \\
\hline & & & & & & & & & & & & & & & \\
\hline $00 \mathrm{minl}$. & 0.2 & (1). 2 & & & & & . & 0.4 & $\cdots$ & $\ldots$ & $\cdots$ & & & & \\
\hline $0 \mathrm{~m} n \mathrm{~m} . \ldots$. & $1.1)$ & $\therefore$ & & & & & & & & $\ldots$ & & & & & \\
\hline $0 \mathrm{~mm} \ldots . . . . . . . .$. & .3 & & & & & & & & & & & & & & \\
\hline 0 m mmi . . . . . . . . & $\begin{array}{l}\ldots \\
.3\end{array}$ & $\cdots$ & 0.8 & & & & & & & $\ldots$ & $\ldots$ & & & & \\
\hline $10 \mathrm{~mm} \ldots \ldots \ldots$ & $\therefore$ & $\therefore 2$ & $\ldots \ldots$ & $\cdots$ & - & & $\ldots$ & $\ldots$ & ... & ... & ... & $\cdots$ & & - & 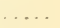 \\
\hline $10 \mathrm{~nm}$ n. . . . . . . . & .3 & .4 & .4 & & & & $\cdots$ & $\cdots$ & $\cdots$ & & & & & & \\
\hline $\begin{array}{l}0 \mathrm{n} \\
10 \mathrm{n} 11 \mathrm{~m} \ldots \ldots \ldots \ldots\end{array}$ & $\because$ & $\begin{array}{l}.4 \\
.4\end{array}$ & $\cdots$ & $(0.0$ & 0.2 & & $\ldots$ & $y_{4}$ & & & & & 11.3 & & \\
\hline $00 \mathrm{~mm} \ldots \ldots \ldots \ldots$ & 1.7 & 1.0 & $\cdots$ & & $\ldots$ & & & .7 & & & & & $\therefore$ & & \\
\hline 30 mи1......... . & 3.5 & 4.8 & & & .4 & & . & 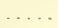 & 1.2 & & & & 3 & 0.2 & \\
\hline $40 \mathrm{~mm} \ldots . . . . . .$. & 10.0 & 7.8 & 2.5 & 3.4 & 5 & & 0.2 & & $.1 ;$ & 3.4 & 0. 4 & & .3 & & 11.5 \\
\hline $50 \mathrm{~mm} \ldots . . . . . .$. & 11.9 & 14.8 & 7.5 & 6.9 & 1. 1 & & 1.0 & ... & 2,6 & 1.8 & .6 & & .9 & .9 & \\
\hline $460 \mathrm{~mm} \ldots . . . . . .$. & 16.6 & 16.4 & 9.0 & 8.9 & 4. 1 & 1.7 & 1.6 & .4 & 5.2 & 7.1 & 1.8 & & .3 & 2.1 & 1.0 \\
\hline $470 \mathrm{~mm} \ldots . . . . . .$. & 17.5 & 16.8 & 9.0 & 8.9 & 7.4 & 5.4 & 4.0 & .8 & 7.6 & 7.1 & 4.0 & & 9 & 2.0 & 1.4 \\
\hline $0 \mathrm{~mm} \ldots . . . . . .$. & 11.2 & 12.2 & 22.0 & 13.8 & 9.2 & 5.4 & 8.0 & 3.6 & 6.0 & 14.3 & 7.6 & 0.6 & 3.0 & 3.3 & 2.9 \\
\hline $90 \mathrm{~mm} \ldots . . . . . . .$. & 7.3 & 7.6 & 8.0 & 12.5 & 9.6 & 5.4 & 12.6 & 5.2 & 5.1 & 14.3 & 12.6 & 1.2 & 3.2 & 3.3 & 3.8 \\
\hline $90 \mathrm{~mm} \ldots . . . . . . .$. & 5.0 & 3.8 & 9.0 & 6.1 & 9.2 & 4.3 & 17.4 & 11.1 & 5.1 & 16. 1 & 11.4 & 1.8 & 7.1 & 3.1 & 4.3 \\
\hline $0 \mathrm{~mm} \ldots . . . . . .$. & 3.8 & 5.0 & 7.5 & 3.4 & 8.0 & 11.8 & 16.6 & 10.0 & 8. 4 & 10.7 & 9.4 & 1.8 & 7.1 & 2.0 & 5.3 \\
\hline $\mathrm{mm} \ldots . . . . . .$. & 3.4 & 3.0 & 6.5 & 6.1 & 8.7 & 19.2 & 11.2 & 11.8 & 12.1 & 14.3 & 4.8 & 3.7 & 11.5 & 3.5 & 5.8 \\
\hline $\mathrm{mm} \ldots . . . . .$. & 1.3 & 3.0 & 9.0 & 8.2 & 11.0 & 18.1 & 7.8 & 7.0 & 12.0 & 1.8 & 5.4 & 6.2 & 11.5 & 11.4 & 9.1 \\
\hline $\mathrm{mm} \ldots . .$. & 1. 1 & 1. 4 & (i. 0 & 6.2 & 10.4 & 15.0 & 5.4 & 10.8 & 14.7 & 5.3 & 7.4 & 9.4 & 14.8 & 18.5 & 12.2 \\
\hline $\mathrm{mm}$. & .5 & .8 & 1.7 & 9.7 & 10.0 & 10.7 & 4.6 & 13.0 & 11.4 & 1.8 & 12.0 & 16.2 & 14.0 & 21.6 & 13.0 \\
\hline mm. & .5 & .4 & $\ldots$. & 3.4 & 6.8 & 3.2 & 4.4 & 8.1 & 5.6 & 1.8 & 9.8 & 25.6 & 13.3 & 14.9 & 17.0 \\
\hline $\mathrm{mm}$.. & . & ... & . & 1.3 & 1.6 & $\ldots \ldots$ & 3.6 & 8.9 & 1.6 & $\ldots$ & 8.4 & 16.8 & 8.6 & 8.5 & 12.7 \\
\hline $30 \mathrm{~mm} \ldots . .$. & .2 & & $\ldots$ & .6 & 1.0 & & 1. 4 & 5.0 & 1.6 & 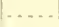 & 3.0 & 10.6 & 1.5 & 3.5 & 6.7 \\
\hline $00 \mathrm{mml} \ldots$ & & & & & & - & $\therefore$ & 2.0 & & & 1. 6 & 4. 4 & $t i$ & .6 & 2.9 \\
\hline$m 11 \ldots . .$. & & & & & & & .2 & .8 & & & .4 & $1 . \AA$ & & $\therefore$ & 1.9 \\
\hline $610 \mathrm{~mm} \ldots$ & & & 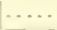 & & & $\ldots$. & .2 & $\ldots$. & .. & $\mid \ldots$. & .... & .6 & $\ldots$. & .2 & 1.0 \\
\hline No. of specime & 528 & 504 & 122 & 146 & 512 & 93 & 502 & 267 & 509 & 56 & 502 & 162 & 333 & 518 & 208 \\
\hline Average length, $\mathrm{mm}$. & 466 & 470 & 488 & 498 & 513 & 528 & 512 & 531 & 516 & 496 & 525 & 555 & 532 & 538 & 543 \\
\hline
\end{tabular}

Table 4a.-Lengtis of Female Sockeyes, Shown as Percentages of the Total Number of Examples Examined for bach Locality.

\begin{tabular}{|c|c|c|c|c|c|c|c|c|c|c|c|c|c|c|c|}
\hline \multirow[t]{2}{*}{ Standard lengths. } & \multirow{2}{*}{$\begin{array}{c}\text { Tam- } \\
\text { gas. } \\
1904\end{array}$} & \multicolumn{2}{|c|}{ Dolomi. } & \multirow{2}{*}{ 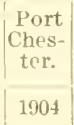 } & \multicolumn{2}{|c|}{$\begin{array}{l}\text { Nowis- } \\
\text { kay. }\end{array}$} & \multicolumn{2}{|c|}{ Quadra. } & \multicolumn{2}{|c|}{ Kegan. } & \multicolumn{2}{|c|}{ Yes Bay. } & \multicolumn{3}{|c|}{$\begin{array}{l}\text { Karta } \\
\text { Bay. }\end{array}$} \\
\hline & & 1904 & 1903 & & 1904 & 1903 & 1904 & 1903 & 1904 & $\mid 1903$ & 1904 & 1903 & 1904 & 1903 & 1905 \\
\hline 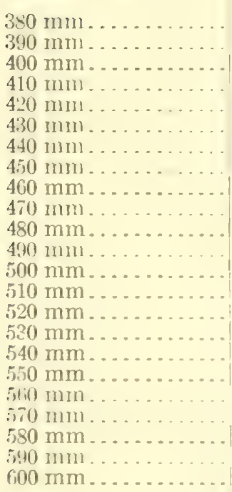 & $\begin{array}{r}0.2 \\
.2 \\
.2 \\
1.9 \\
4.9 \\
11.7 \\
20.0 \\
20.7 \\
11.0 \\
8.8 \\
4.3 \\
2.7 \\
4.3 \\
2.9 \\
1.1 \\
2 \\
.2\end{array}$ & \begin{tabular}{|r|}
0.4 \\
.6 \\
1.0 \\
5.0 \\
6.8 \\
13.2 \\
$\mid 17.0$ \\
$\mid(1) .2$ \\
14.4 \\
8.0 \\
5.8 \\
3.6 \\
2.2 \\
1.8 \\
.6 \\
.4
\end{tabular} \mid & $\begin{array}{r}0.6 \\
1.1 \\
2.2 \\
1.0 \\
11.1 \\
20.0 \\
20.5 \\
15.0 \\
6.0 \\
6.5 \\
3.8 \\
3.8 \\
.5 \\
.5\end{array}$ & $\begin{array}{r}0.6 \\
2.0 \\
5.2 \\
9.7 \\
13.0 \\
11.0 \\
33.0 \\
6.7 \\
4.6 \\
5.8 \\
8.5 \\
9.0 \\
5.8 \\
1.2 \\
.16\end{array}$ & $\begin{array}{r}1.1 \\
2.9 \\
4.1 \\
7.4 \\
6.0 \\
8.4 \\
7.2 \\
10.0 \\
14.9 \\
15.0 \\
12.7 \\
4.8 \\
3.1 \\
.8 \\
.2\end{array}$ & $\begin{array}{r}1.0 \\
2.8 \\
3.7 \\
1.0 \\
2.5 \\
7.5 \\
16.0 \\
24.3 \\
17.7 \\
14.0 \\
5.6 \\
3.7 \\
\ldots .\end{array}$ & $\begin{array}{r}0.6 \\
2.0 \\
5.4 \\
11.4 \\
1.4 .2 \\
16.1 \\
11.0 \\
7.6 \\
7.2 \\
7.0 \\
8.6 \\
5.6 \\
2.4 \\
1.2 \\
.2 \\
.2\end{array}$ & \begin{tabular}{r|}
0.4 \\
.8 \\
1.2 \\
2.0 \\
$2 . .5$ \\
5.1 \\
5.5 \\
5.1 \\
14.6 \\
21.9 \\
18.2 \\
13.8 \\
5.1 \\
1.6 \\
1.6
\end{tabular} & $\begin{array}{r}0.2 \\
.4 \\
1.0 \\
1.7 \\
2.3 \\
3.1 \\
3.5 \\
3.1 \\
6.9 \\
14.2 \\
18.5 \\
19.5 \\
19.9 \\
7.7 \\
1.3 \\
.2\end{array}$ & $\begin{array}{r}7.0 \\
\mid 9.0 \\
1.5 \\
\mid 15.9 \\
11.5 \\
4.5 \\
4.5 \\
7.0 \\
13.6 \\
7.0 \\
2.3 \\
2.3\end{array} \mid$ & $\begin{array}{r}0.4 \\
1.4 \\
2.0 \\
4.4 \\
7.0 \\
5.0 \\
4.6 \\
4.8 \\
11.6 \\
17.4 \\
18.2 \\
14.2 \\
1.6 \\
2.2 \\
2.6\end{array}$ & \begin{tabular}{r}
0.7 \\
$\ldots \ldots$ \\
\hdashline 9.0 \\
19.3 \\
23.7 \\
22.2 \\
12.1 \\
10.0 \\
1.5
\end{tabular} & $\begin{array}{r}0.2 \\
.2 \\
1.0 \\
\mid .8 \\
1.8 \\
1.1 \\
1.9 \\
6.7 \\
13.4 \\
21.9 \\
21.5 \\
12.2 \\
11.6 \\
2.7 \\
.4\end{array}$ & \begin{tabular}{|c|}
0.5 \\
$\ldots .$. \\
$\mid .5$ \\
2.3 \\
1.4 \\
3.3 \\
4.2 \\
8.4 \\
17.8 \\
27.2 \\
19.2 \\
11.2 \\
3.0 \\
1.0
\end{tabular} & $\begin{array}{r}1.4 \\
1.4 \\
3.5 \\
4.5 \\
9.3 \\
15.6 \\
23.5 \\
19.0 \\
15.3 \\
6.2 \\
1.7\end{array}$ \\
\hline Average length, $\mathrm{mm}$. & $\begin{array}{l}512 \\
464\end{array}$ & $\begin{array}{l}506 \\
471\end{array}$ & 483 & 486 & 519 & 500 & 512 & 537 & 517 & 495 & 523 & $\begin{array}{l}135 \\
544\end{array}$ & 524 & 536 & $\begin{array}{l}353 \\
530\end{array}$ \\
\hline
\end{tabular}




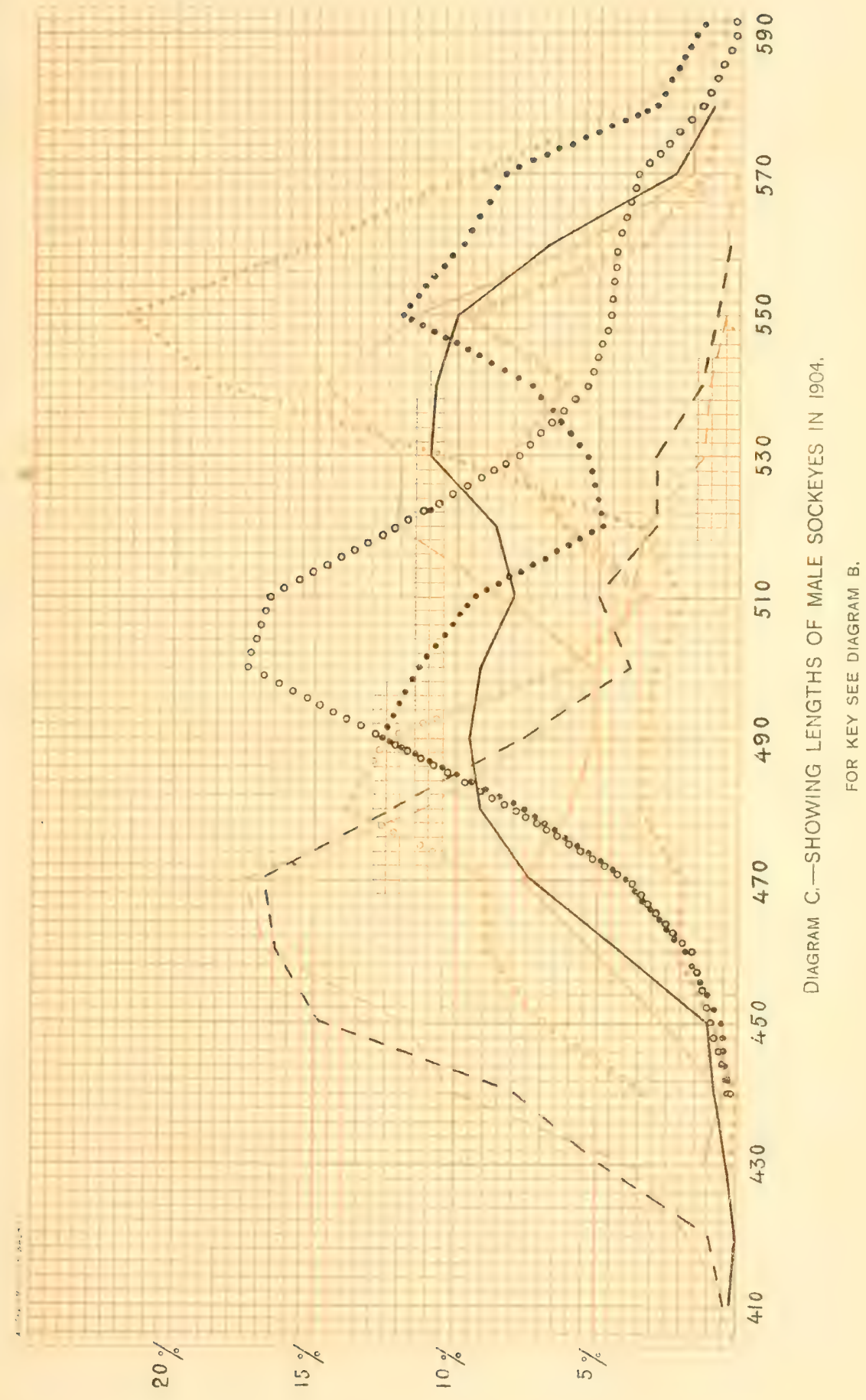





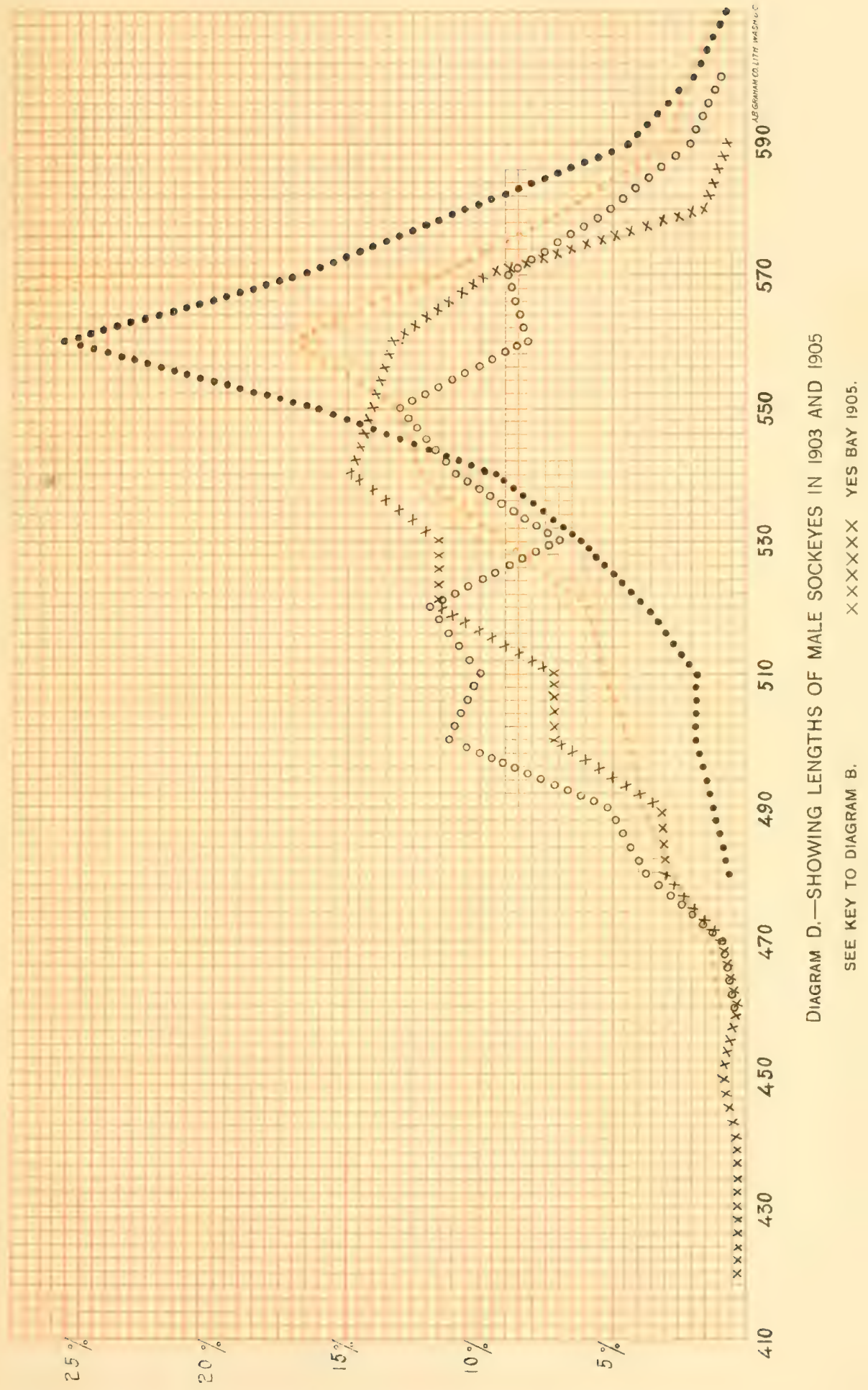



Table 5 shows the depths of the males tabulated in the same manner as the lengths and weights, showing these measurements in percentages of the total number of fish in each lot measured. Diagram $\mathrm{E}$ presents the same information for 1904 shown by curves.

Table 5.-Depths of Male Sockeyes, Shown as Percentages of the Total Number of Examples Examined for Fach Locality.

\begin{tabular}{|c|c|c|c|c|c|c|c|c|c|c|c|c|c|c|c|}
\hline \multirow{2}{*}{ Depth. } & \multirow{2}{*}{$\begin{array}{l}\text { Tam- } \\
\text { gas. } \\
1904\end{array}$} & \multicolumn{2}{|c|}{ Dolomi. } & $\begin{array}{l}\text { Port } \\
\text { Ches- } \\
\text { ter. }\end{array}$ & \multicolumn{2}{|c|}{ Quadra. } & \multicolumn{2}{|c|}{$\begin{array}{c}\text { Nowis- } \\
\text { kny. }\end{array}$} & \multicolumn{2}{|c|}{ Kegan. } & \multicolumn{2}{|c|}{$\begin{array}{c}\text { Karta } \\
\text { Bay. }\end{array}$} & \multicolumn{3}{|c|}{ Yes Bay. } \\
\hline & & 1904 & 1903 & 1904 & 1904 & 1903 & 1904 & 1903 & 1904 & 1903 & 1904 & 1903 & 1904 & 1903 & 1905 \\
\hline$m m \ldots . . . . .$. & 0.4 & & & & & & & & & & & & & & \\
\hline${ }_{1}{ }_{1} \ldots \ldots \ldots \ldots \ldots$ & .15 & & & & & & & . & $\ldots$. & $\cdots$ & $\cdots$ & $\cdots$ & $\cdots$ & $\cdot$ & . \\
\hline 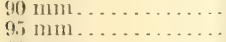 & 1.0 & 0. 4 & & & & & - & ... & $\cdots$ & $\ldots$ & $\ldots$ & $\cdots$ & $\cdots$ & $\cdots$ & $\cdots$ \\
\hline $00 \mathrm{mmm} . .$. & 1. 2 & .4 & & & & & & & & & & & & & - \\
\hline $0.5 \mathrm{~mm} \ldots$ & $\frac{2.0}{7.7}$ & .6 & 0.5 & 2. & & & & & & & & & & & \\
\hline $10 \mathrm{mmm} .$. & $16 . .4$ & 6.1 & $\begin{array}{l}4.0 \\
4.0\end{array}$ & $\begin{array}{l}1.3 \\
7.3\end{array}$ & 0.2 & & 0.4 & & & 1. & & & & & \\
\hline $5 \mathrm{~mm} \ldots \ldots \ldots$ & 24.0 & 19.0 & 7. 4 & 10.6 & .6 & & .8 & & 0.4 & & & 0.9 & & & \\
\hline $0 \mathrm{~mm} \ldots . . . . . .$. & 19.2 & 26.3 & 22.0 & 15.3 & .4 & & 2.3 & 3.2 & 2,5 & 10.7 & $i . i$ & 1. 4 & & & $\cdots$ \\
\hline $125 \mathrm{~nm} \ldots . . . . .$. & 13.2 & 22.7 & 18.0 & 11.3 & 5.2 & 0.4 & 6.5 & 5.4 & 5.5 & 5.3 & 1.3 & 1.9 & 1,4 & & 0.3 \\
\hline $30 \mathrm{~mm}$... & 7. 6 & 12.5 & 13.0 & 15.3 & 13.4 & 2. 9 & 11.2 & 8. 6 & 10.7 & 8. 9 & 4.0 & 7.7 & 2.4 & & 0.3 \\
\hline $35 \mathrm{~mm} \ldots . . . .$. & 3. 4 & 7.0 & 14.0 & 8.0 & 19.6 & 10.6 & 14.9 & 10.8 & 13.5 & 36.0 & 4.8 & 8.2 & 5.8 & 1.2 & 1.8 \\
\hline $40 \mathrm{~mm} \ldots . . .$. & 2.0 & 2.8 & 6.5 & 8.0 & 25.2 & 19.9 & 16.0 & 14.0 & 12.3 & 18.0 & 11.7 & 11.0 & 15,4 & 1.8 & 1.8 \\
\hline $45 \mathrm{~mm}$. & .6 & 1.4 & 4.8 & 8. 0 & 16.4 & 17.0 & 15.8 & 16. 1 & 15.1 & 8.9 & 14.0 & 24.0 & 13.8 & 6.0 & $\begin{array}{l}2.3 \\
4.7\end{array}$ \\
\hline $150 \mathrm{~mm} \ldots . . . .$. & $\ldots$. & .2 & 4. 0 & 8.0 & 9.2 & 20.1 & 17.0 & 24.9 & 20.6 & 8.9 & 28.3 & 17.3 & 16.4 & 12.8 & 7. 4 \\
\hline $155 \mathrm{~mm} . . . . . .$. & .2 & .2 & .8 & .2 & 5.0 & 13.0 & 8. 3 & 13.0 & 11.9 & $\ldots$ & 20.0 & 15.4 & 11.6 & 20.0 & 14.5 \\
\hline $160 \mathrm{~mm} \ldots \ldots . .$. & & & $\ldots$. & $\ldots$ & 4. 0 & 8. 7 & 6.0 & 3.2 & 5.3 & - & 10.6 & 7.7 & 14.6 & 25.6 & 20.9 \\
\hline $16 i 5 \mathrm{~mm} . .$. & & & & & 1.0 & (i. 0 & 1.0 & & 2.5 & & 3.1 & 3.3 & 9.6 & 17.2 & 21.8 \\
\hline $170 \mathrm{~mm} \ldots$ & & & & & 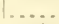 & 2.3 & & & $1 \ldots$. & $\ldots$ & .6 & 1.9 & 6.8 & 10.0 & 13.0 \\
\hline $175 \mathrm{~mm} \ldots$ & & & & & .2 & & & & & & & & 2.6 & 4.9 & 7. 4 \\
\hline $180 \mathrm{mm11} . .$. & & & & & & & & & & & & & $\therefore$ & $.6 i$ & 4. 1 \\
\hline Ift min . . . . . . . & $\cdots$ & $\cdots$ & & ․ & $\ldots$ & 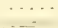 & & & $\because$ & $\cdots$ & - & $\ldots$ & $\ldots$ & $=6$ & .6 \\
\hline No, of specimens.... & 528 & 505 & 122 & 150 & 503 & 265 & 512 & 93 & 509 & 56 & 518 & 208 & 503 & 164 & 339 \\
\hline $\mathrm{n}, \mathrm{mm}$. & $114+$ & 121 & $125-$ & $126+$ & $138+$ & $145-$ & $140-$ & $140-$ & $141+$ & 134 & $147-$ & $144+$ & $151-$ & 159 & 158 \\
\hline
\end{tabular}

A close correspondence will be seen in all the curves for Dolomi and Tamgas. ${ }^{a}$ The greatest number of individuals in each are t-pound fish. The balance of the average weights of the two lots is destroyed by the varying numbers under and over this maximum. The weight curve, however, for Dolomi is very similar to that for Tamgas, though it occupies a place about 0.5 pound higher in the scale, the average weight for Dolomi being 4.5 pounds as compared with 3.9 pounds. An examination of the length curves (diagram $\mathrm{E}$ ) also shows a very close parallel between these two localities, while the difference between the curves for depths (diagram $\mathrm{F}$ ) will explain the greater weight of the Dolomi examples, the depth curve for Dolomi standing about 5 $\mathrm{mm}$. higher on the scale than that for Tangas. Comparing the two lots, it is shown that while the average length is about the same for each locality, and the number of examples of any given length is about the same for each, the Dolomi fish average about $5 \mathrm{~mm}$. greater in depth and therewith 0.5 pound greater in weight. These two localities seem to be set off clearly from all others examined.

an the following discussion of the tabular data reference is to the males only unless otherwise specified. 
The Dolomi fish of 1903 , only 200 in number, were much heavier than those of 1904 , but in this they but follow the rule exhibited by other localities, in almost all of which the 1904 fish are lighter than those of the previous year. It will be noted that in 1904 the examination of Dolomi fish preceded that of 'Tamgas fish by about two weeks. The latter were reported to be quite immature sexually, apparently more so than the Dolomi fish of the earlier date. 'This may account in a measure for their slenderness. In both these localities rumning small fish, two type forms are noted more distinctly than in streams (arrving the larger fish, viz, the slender terete form, usually dark, with scales more or less embedded, but not showing the other marks of sex maturity; and the deeper, more compressed form, with seales distinct and hrieghty colored. Fassett noted at Tamgas that one or the other of these forms predominated on different days, indicating a difference in schools. The dark fish may be fish which have been feeding in the brackish water for some time.

The fish of Karta and Yeshays, the heaviest of all, in 1904 approarhed one another closely in average weight, varying only 0.3 pound. Examination of the curves for weight, however, shows great difference. The curve for Karta Bay is comparatively simple, rising to orer " 4 per cent on 7 pounds, extremes falling between 3.5 and 9.5 pounds and showing little tendency to indicate a double node or maximum, while Yes Bay shows 2 maxima, one on 6 pounds and one on 8 pounds, with small numbers on 7 and 7.5 ; in addition the upper extreme rises to 10.5 pounds. The length curves exhibit this variance increased. In this the line for Karta, showing some tendency to form a double node, rises on the same maxima with Yes Bay, $490 \mathrm{~mm}$. for the lower, and $550 \mathrm{~mm}$. for the upper, but in the case of Yes Bay the percentages on each are about equal (12 per cent), while for Kint a they are, respectively, $3+$ and 21.5 per cent. This shows that the relatively short fish are found in much greater number among the Yes Bay examples, reducing the total average length (std.) in this locality to $525 \mathrm{~mm}$. as against 5.38 at. Karta, in the face of a slightly higher average weight for Ves Bay. Reference to the depth curve again oflers the explanation. The two lengeth types of Tes Bay cause the depth curve for that locality to be somewhat truncated, rising to about equal height (1+ to 16 per (cent) on 140, 150, $160 \mathrm{~mm}$, and reaching an extreme of $180 \mathrm{~mm}$. This indicates the prevalence of short deep fish in Tes Bay and long slender fish in Karta Bay.

In this year the Karta fish were examined about six weeks earlier than those of Yes Bay. They were noted as nearly all bright, lout. some were of advanced maturity, with the usual changed form. The Tes Bay fish were noted as heing of "advanced" maturity in outward appearance, and it was said they were so from the begiming of the rum. The catches made in Behm Canal averaged smaller fish and 


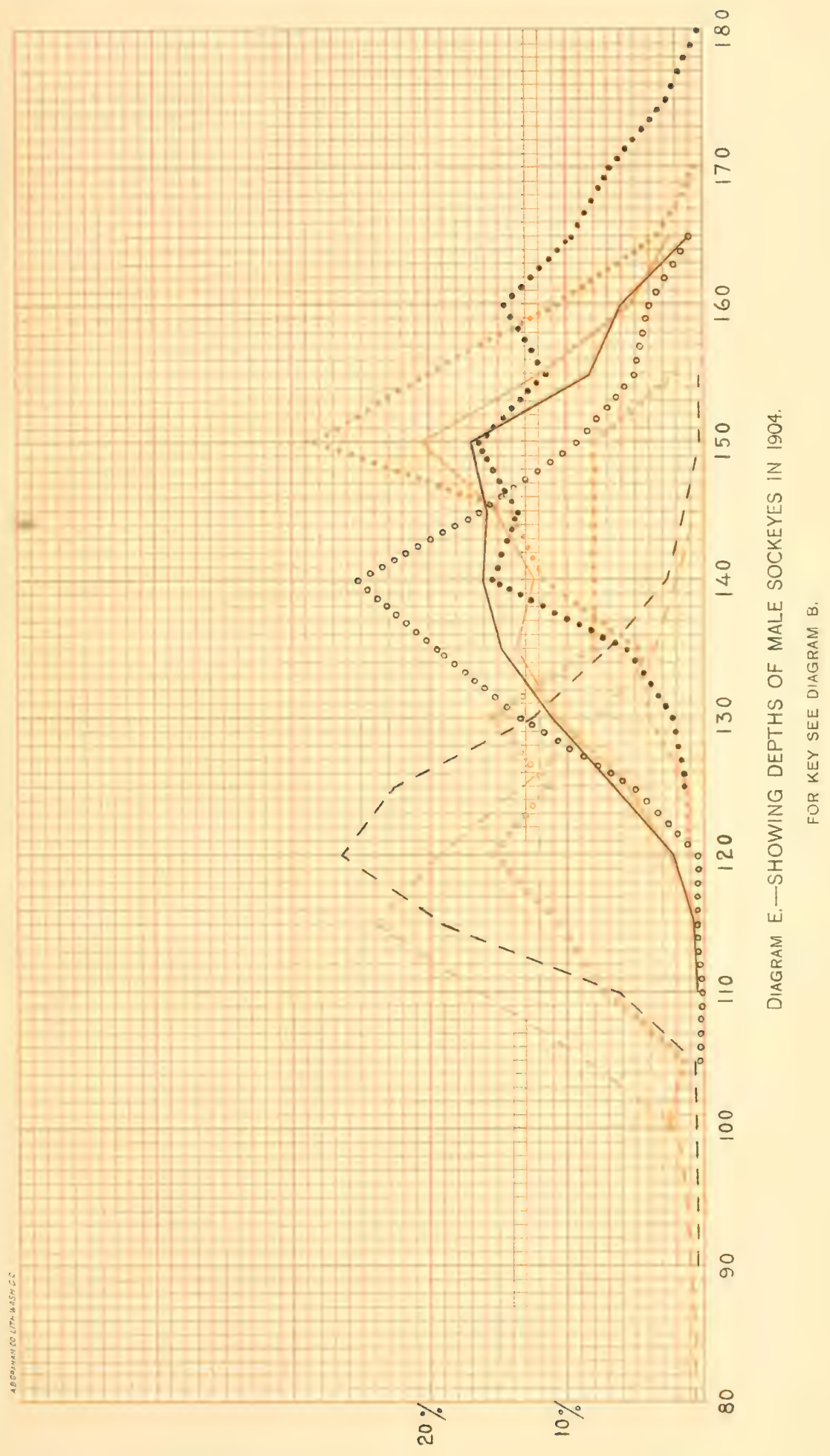



brighter. The fishermen thought these were "Unuk River fish." Whether regarded as fish traveling to another hasin or as a later run not yet ready to enter the bay, these smaller fish account for the abundance of 6-pound fish and the double node in the curve. In 190:3 the fish of these two localities, examined at approximately the same time, differed much more in averages, the les Bay fish exceeding those of Karta Bay by more than 1 pound in weight, hy 12 mm. in length, and about $15 \mathrm{~mm}$. in depth. In neither is there an indieation of more than one type. The curves for length, weight, and depth show a single maximum, that for length in both localities on 560 mm., for weight on 7.5 and 8 pounds, respectively, for Kart a and Yes bars, and for depth on 145 and $160 \mathrm{~mm}$. Over 25 per cent of the Yes Bay fish reach the maximum, while of the Kiarta fish less than 2() per cent are of maximum weight and length and 24 per cent are of maximum depth. This indicates, again, that increased weight is largely due to increased depth. In condition the Karta fish of this year were noted as being quite as' much, if not more, advanced than the Yes Bay. This applies rather to the last lot of 153 , examined July $2: 3$ to 26 , in which the shorter fish predominated, only 45 per cent beting over 550 () mm. in length, while of the first lot of 5.5, examined July 1, 62 per cent were of that length. In the two lots from Yes Bay the curve for that of 1903, taken earliest-about a month earlier than the 1904 lot -is much more like the curves for Karta than like that of Yes Bay for 1904, rising to over 25 per cent on $560 \mathrm{~mm}$., with extremes between 480 and 610 . In 1905 the values are more distributed, varying between 10 and 15 per cent from 520 to $570 \mathrm{~mm}$., with extremes between 420 and 590 . The average lengths, respectively, of the 1903 and 1905 examples are 55.5 and $5: 32 \mathrm{~mm}$, the average depths approximating $158 \mathrm{~mm}$. in both cases, while the weights are 8.3 and 8.2 pounds. This indicates that the fish of 1905 were more of the deep form, while those of 1903 were rather long and comparatively slender. These 1903 fish were from the early part of the run, those of 1905 some weeks later, giving another example of the long slender type form in the early rum. On the whole, it seems that Yes Bay fish may be said to be deeper than the Karta fish of corresponding maturity, and that the early fish of both localities are of less depth and weight for corresponding length than later fish.

Quadra and the Moira Sound streams, Kegan and Nowiskay, show an almost exactly equal average weight in the fish examined in 1904, as well as close similarity in the averages of length and depth. Inspection of the curves, however, shows this similarity to be factitious. The Quadra fish are a symmetrical group, while the Moira Sound fish are, like Yes Bay, composite, apparently made of a short deep rype. and another correspondingly longer and more slender. 
In Quadra fish taken in 1903, about one month earlier than the $190+$ lot, the length curve shows much variation (see diagram $a_{\text {i }}$. The average length is nearly 20 mm. crreater than in 1904, and the curve zigzags between 500 and $570 \mathrm{~mm}$. across the $10 \mathrm{per}$ cent line, while in 1904 it shows a single rise to about 17 per cent on 500 and $510 \mathrm{~mm}$. The difference in average length, weight, and depth of Quadra fish in the two seasons of 1903 and 1904 is very close to that of Yes Bay fish for the same years. The curves, however, are quite unlike, that of Quadra for 190)3 being compound, while that for I es Bay is simple. It was noted that the Quadra fish of 190:3, though examined later than those of Yes and Karta bays, were less developed sexually. In almost all cases the curves for the females, though cuite similar in general form, exhibit less complexity than the curves for the males. (See tables 4 and $4 \mathrm{a}$, p. 84.) In no case is the curve of such a character as clearly to indicate fish of different ages, though it is possible that such curves as that for Yes Bay in 1904 may be so accounted for. The maxima in this case, separated by 60) mm. (so) total length) and 2 pounds, would seem to be about what might be expected for the difference between a 3-year and a 4-year fish. In the females the maxima of length are separated by the same interval and the much lower percentage of the lower maximum accords with what is known of the development of the king salmon in captivity, in which the males exhibit much the greater precocity.

Of the occurrence of the grilse form, or Arctic salmon, we know little, for the reason that many doubtless pass the meshes of the nets, and many are unreported by the fishermen, since they are not taken as "counts." At Quadra, of the sockeyes delivered at the scow about 1 in 300 were grilse. This is, perhaps, not far from the average ratio in the Loring district. They were not noted in unusual number at Dolomi. The Moira Sound fish examined in 19(3):3 are too few to be of any value in the present comparisons.

The increase of relative depth in the later fish may indicate only the chance incident to sex maturation. It carries with it, however, a corresponding increase in weight. If it is not a typical form, but merely a sex character, then the early run ascends the stream with a smaller amount of tissue deposit than later rums, else they do not first enter the bay for the purpose of ascending the stream, but return again, if not hindered, to the feeding grounds.

Such observations as could be made in opening the fish for determination of sex did not indicate that the difference in sex maturity of the different parts (seasons) of the run are material until after the main body has arrived. The late arrivals-the last week or so of the regular rum and belated sections-do show marked advance of sex maturity. It is probable that careful measurements would show a gradual increase in relative maturity, but not proportionate 
to the difference in time at which the different schools arrive at the breeding stream.

Tariations in counts. - For a further test of the similarity of fishes from a given basin, counts were made of the dorsal and anal fin rays, the branchiostegal rays, and of the tubes of the lateral line and number of longitudinal rows of scales. These various counts are tabulated in the same manner as the measurements, except that sexes are not differentiated, percentages being used instead of the number of examples in order to make comparable the results for the diflerent, sized lots that were obtained. In the fin-ray counts the totals of rudimentary and branched rays are used, but the terminal half ray, which varies greatly in development, is in all cases omitted.

In table 6, showing the counts for dorsal rays, the similarity of the two years for each of the various localities is striking; Ios Bay, Karta, and Quadra exhibit the maximum on 15 rays, while Dolomi and the two Moira Sound points give it to the next lower number, or 14 rays; 12 and 17 are the extremes. The averages differ very slightly; Karth Bay is highest with 14.7 and Nowiskay lowest with 14.3. It is noteworthy that these two localities were examined in sequence in 1904 , and the field notes eall attention to the exact identity of method in recording the fin counts.

Table 6.-Dorsal Fin-Ray Count.

\begin{tabular}{|c|c|c|c|c|c|c|c|c|c|c|}
\hline \multirow{2}{*}{ Locality. } & \multirow{2}{*}{ Date. } & \multirow{2}{*}{$\begin{array}{l}\text { Number } \\
\text { exam- } \\
\text { ined. }\end{array}$} & \multirow{2}{*}{$\begin{array}{l}\text { A verage } \\
\text { number } \\
\text { of rily's. }\end{array}$} & \multicolumn{7}{|c|}{$\begin{array}{l}\text { Percentage of fish with specified numbers } \\
\text {.of rays-- }\end{array}$} \\
\hline & & & & 12 & 13 & 14 & 1.5 & $16 \mathrm{i}$ & 17 & 18 \\
\hline \multirow{2}{*}{ Karta Bay. } & 1904 & 512 & 14.7 & & 0.6 & 31.6 & 60.9 & 6.8 & & \\
\hline & 1903 & 420 & 14.8 & & .5 & 29.0 & 63.1 & 7.1 & 0.2 & \\
\hline Yes Bay.. & $\begin{array}{l}1904 \\
1903\end{array}$ & $\begin{array}{l}509 \\
300\end{array}$ & $\begin{array}{l}14.5 \\
14.6\end{array}$ & & $\begin{array}{l}1.7 \\
1.6\end{array}$ & $\begin{array}{l}41.5 \\
36.3\end{array}$ & $\begin{array}{l}53.8 \\
61.0\end{array}$ & $\begin{array}{r}2.5 \\
.6\end{array}$ & .4 & \\
\hline \multirow{2}{*}{$\begin{array}{l}\text { Quadra.. } \\
\text { Kegan... }\end{array}$} & 1904 & 512 & 14.5 & & 2.3 & 44.0 & 51.7 & 2.1 & .2 & 0.2 \\
\hline & 1903 & 500 & 14.5 & & 2.6 & 42.4 & 51.2 & 3.8 & & .0 \\
\hline \multirow{2}{*}{$\begin{array}{l}\text { Kegan... } \\
\text { Dolomi... }\end{array}$} & 1904 & 511 & 14.4 & & 2.5 & 54.2 & 41.3 & 1.9 & & \\
\hline & $\begin{array}{l}1903 \\
1904\end{array}$ & 100 & 14.4 & & 2.0 & 57.0 & 40.0 & 1.0 & & \\
\hline Dolomi............. & 1903 & $\begin{array}{l}511 \\
200\end{array}$ & $\begin{array}{l}14.4 \\
14.4\end{array}$ & 0.2 & $\begin{array}{l}2.5 \\
3.0\end{array}$ & $\begin{array}{l}53.7 \\
53.5\end{array}$ & $\begin{array}{l}41.2 \\
41.0\end{array}$ & $\begin{array}{l}1.9 \\
2.5\end{array}$ & & . \\
\hline \multirow[t]{2}{*}{ Nowiskay.......... } & 1904 & 513 & 14.3 & & 5.4 & 58.2 & 34.1 & 1.9 & & $\cdots$ \\
\hline & 1903 & 100 & 14.3 & & 7.0 & 61.0 & 30.0 & 2.0 & & \\
\hline
\end{tabular}

In the anals (table 7 ) the parallel is less sharply defined but still characteristic. All reach the maximum on 18 except Dolomi and Nowiskay in 1904, which rise highest on 17 . The extremes are 15 and 20. Quadra shows the lowest pereentage on 17 and highest on 19. The averages vary from 18.2 at Quadra to 17.3 at Nowiskay. The order of localities as to number of rays is changed from that of the dorsals, though the Moira Sound streams are still lowest. 
Tabie 7.-Anai Fin-Ray Count.

\begin{tabular}{|c|c|c|c|c|c|c|c|c|c|}
\hline & & & & & & & & & \\
\hline Locality. & Date. & $\begin{array}{l}\text { Number } \\
\text { exam- }\end{array}$ & $\begin{array}{l}\text { A verage } \\
\text { ntumber }\end{array}$ & I'el & $\begin{array}{r}\text { ntage } \\
\text { n }\end{array}$ & $\begin{array}{l}\text { of } \\
\text { mbers }\end{array}$ & $\begin{array}{l}\text { h wi } \\
\text { f rays }\end{array}$ & spec & ified \\
\hline & & ined. & of rays. & 15 & 16 & 17 & 18 & 19 & 20 \\
\hline Quadra. & 1904 & 512 & 18.2 & & 0.4 & 10.9 & 54.1 & 32.6 & 1.6 \\
\hline & 1903 & 499 & 18.2 & & $\ldots$ & 13.0 & 55.4 & 29.2 & 2.0 \\
\hline Yes B:y. & 1904 & 508 & 18.0 & ... & .6 & 16.1 & 63.4 & 19.0 & 1.0 \\
\hline & 1903 & 300 & 18.0 & $\ldots$ & .3 & 14.0 & 69.0 & 16.3 & .3 \\
\hline Karta Bay.. & 1904 & 512 & 17.8 & $\ldots$ & .2 & 25.9 & 60.0 & 13.8 & $\ldots$ \\
\hline & 1903 & 420 & 17.8 & $\ldots$ & .2 & 27.1 & 63.8 & 8.8 & $\ldots$. \\
\hline Kegan.. & 1904 & 510 & 17.7 & 0.2 & 1.1 & 29.4 & 61.7 & 7.4 & $\ldots$. \\
\hline & 1903 & 100 & 17.8 & $\ldots$. & 2.0 & 32.0 & 56.0 & 8.0 & .2 \\
\hline Dolomi... & 1904 & 511 & 17.3 & $\ldots$ & 2.0 & 48.5 & 46.6 & 2.9 & $\ldots$ \\
\hline & $\begin{array}{l}1903 \\
1904\end{array}$ & $\begin{array}{l}200 \\
513\end{array}$ & $\begin{array}{l}17.4 \\
17.3\end{array}$ & i) & $\begin{array}{l}6.5 \\
6.4\end{array}$ & $\begin{array}{l}42.5 \\
50.1\end{array}$ & $\begin{array}{l}48.0 \\
41.3\end{array}$ & $\begin{array}{l}3.0 \\
1.7\end{array}$ & \\
\hline Nowiskity.. & 1903 & 100 & 17.4 & & 7.0 & 44.0 & 46.0 & 3.0 & \\
\hline
\end{tabular}

The branchiostegal rays exhibit little local variation in number. The maximum in practically all cases falls on 14/13, the left orerlapping membrane carrying the extra ray; about one-third the fotal occurs on this maximum. Extremes are 12/11 and 16/15. Quadra and Kexan resemble one another in rising high on 13/13 and failing low on $14 / 14$ and the higher counts. Karta and Dolomi exhibit the highest counts on 14/14. In no instance was a clearly defined case of right overlapping seen, though occasionally the right membrane carries the higher number of rays.

Table 8.-Branchiostegat Ray Count.

\begin{tabular}{|c|c|c|c|c|c|c|c|c|c|c|c|c|c|}
\hline \multirow[b]{2}{*}{ Loeality. } & \multirow[b]{2}{*}{ Date. } & \multirow{2}{*}{$\begin{array}{l}\text { Num- } \\
\text { ber } \\
\text { exam- } \\
\text { ined. }\end{array}$} & \multicolumn{10}{|c|}{ Pereentage of fish with specified branchiostegal counts- } & \multirow[b]{2}{*}{$13 / 14$} \\
\hline & & & $11 / 11$ & $11 / 13$ & $13 / 15$ & $14 / 11$ & $12 / 11$ & $12 / 14$ & $13 / 11$ & $12 / 13$ & $12 / 12$ & $14 / 12$ & \\
\hline Karta. & 1904 & $\begin{array}{l}511 \\
420\end{array}$ & & & & & 0.2 & 0.4 & 0.4 & 0.4 & 0.2 & 1.0 & 3.1 \\
\hline Kegan & 1901 & 511 & & 0.2 & & 0.2 & & 2 & -4 & 2.5 & 2.9 & 3.5 & .8 \\
\hline & 1903 & 100 & & . & & & 1.0 & & & 2.0 & 2.0 & 2.0 & 4. \\
\hline Nowiskay & 1904 & 513 & & & .2 & & $\ldots \ldots$ & & .4 & 1.0 & .2 & .4 & 2.1 \\
\hline & 1903 & 100 & & & & 1.0 & & & $\ldots \ldots$ & $\ldots$. & 1.0 & 2.0 & 3. \\
\hline Dolomi . & 1904 & 511 & & 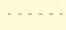 & & ....... & .2 & $\ldots .$. & $\ldots$ & .2 & 1.0 & .8 & 1. \\
\hline Ont & & $\begin{array}{l}200 \\
512\end{array}$ & 0.2 & & & $\cdots$ & $\begin{array}{r}.5 \\
2\end{array}$ & & & $\begin{array}{r}1.3 \\
.8\end{array}$ & $\begin{array}{l}2.0 \\
2.1\end{array}$ & 1.5 & $\begin{array}{l}3.5 \\
2.0\end{array}$ \\
\hline QU & 1903 & 500 & 0.2 & & & & .2 & $\begin{array}{l}x \\
.2\end{array}$ & .4 & 2.2 & 3.4 & .8 & 3.0 \\
\hline Tes Bay & $\begin{array}{l}1904 \\
1903\end{array}$ & $\begin{array}{l}508 \\
300\end{array}$ & & & & & $\ldots \ldots$ & $\cdots$ & $\cdots$ & $\begin{array}{r}.4 \\
.6\end{array}$ & $\begin{array}{l}4 \\
3\end{array}$ & $\begin{array}{l}2.7 \\
1.3\end{array}$ & $\begin{array}{l}1.7 \\
2.3\end{array}$ \\
\hline
\end{tabular}

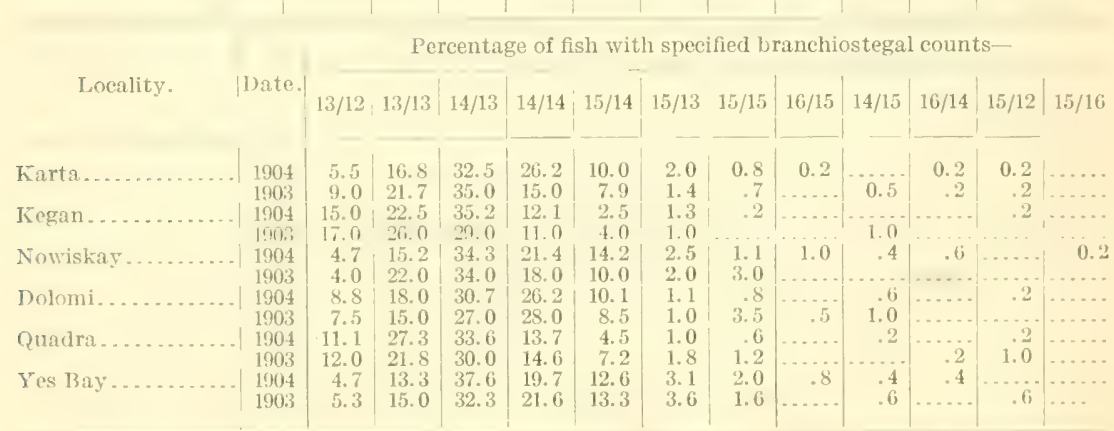


In the number of tubes in the lateral line (table 9) no great local variation was found, the averages varying from 132.1 to 135 , with extremes 126 and 143 . The value of this count is somewhat lessened by the varying degree to which the tubes extend on the caudal. This does not imply that all the high counts are due to this; in some instances high counts are due to the finer scaling. In other cases even low counts continued well on to caudal. 'The averages for the different years, however, show a striking similarity. The maxima vary from 132 for Karta in 1904 to 135 for Dolomi in 1903, but mostly fall on 133 .

Table 9.-Tubes of Lateraid Line.

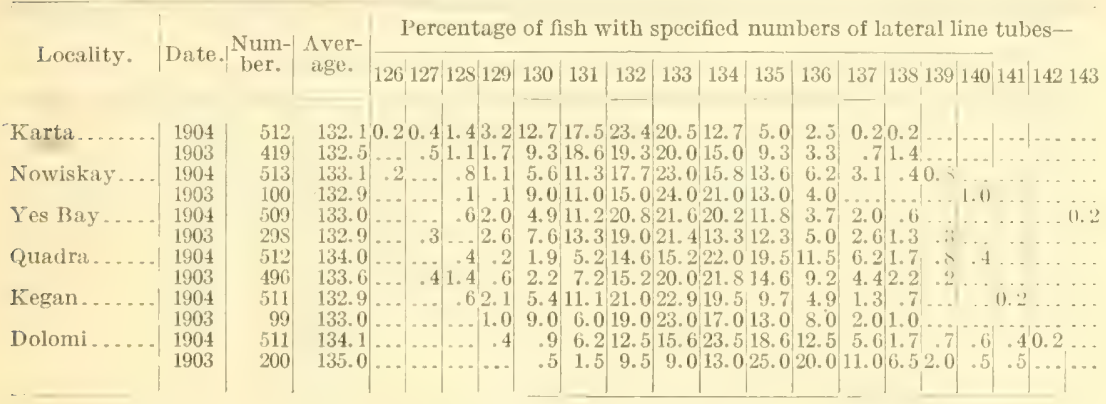

In table 10, showing rows of scales, it will be seen that the counts for 1903 regularly fall below those for 1904 . This is due to the varying procedure regarding the fine rows in front of dorsal and rentral fins, where the counts were initiated. A considerable variance is thus introduced. The branching of the rows under the front of the dorsal also affected the aceuraey of the count. In some specinems a few seales difference in the point at which this branching oceurs adds or excludes a row in the count, which was made for the top rows from front of rayed dorsal down to lateral line, and for lower rows from front of ventrals up to lateral line, the lateral row being included in the total.

TABLE 10.-Rows of SCAles.

\begin{tabular}{|c|c|c|c|c|c|c|c|c|c|c|c|c|c|c|c|c|c|c|}
\hline \multirow[b]{2}{*}{ Locality. } & \multirow[b]{2}{*}{ Date. } & \multirow{2}{*}{$\begin{array}{l}\text { Num- } \\
\text { ber } \\
\text { exam- } \\
\text { ined. }\end{array}$} & \multirow[b]{2}{*}{$\begin{array}{c}\text { Aver- } \\
\text { age. }\end{array}$} & \multicolumn{15}{|c|}{ Percentage of fish with specified numbers of rows of scales- } \\
\hline & & & & 38 & 39 & 40 & 41 & 42 & 43 & 44 & 45 & 46 & 47 & 48 & 49 & 50 & 51 & 52 \\
\hline Dolomi & 1904 & & 44. 0 & 0.2 & 0.4 & 1.3 & 6. 61 & 11.5 & 18.5 & 21.1 & 20.5 & 11.3 & 5.6 & 1.9 & 0.6 & & & \\
\hline Kegar & $\begin{array}{l}1903 \\
1904\end{array}$ & $\begin{array}{l}200 \\
511\end{array}$ & $\begin{array}{l}43.0 \\
44.5\end{array}$ & & $\begin{array}{r}2.5 \\
.6\end{array}$ & 3.51 & $\begin{array}{rl}16.0 & 2 \\
3.5 & 1\end{array}$ & $\begin{array}{l}21.5 \\
10.0\end{array}$ & $\begin{array}{l}24.0 \\
14.0\end{array}$ & $\begin{array}{l}18.5 \\
18.7\end{array}$ & $\begin{array}{r}9.0 \\
22.5\end{array}$ & $\begin{array}{r}3.5 \\
16.4\end{array}$ & $\begin{array}{l}1.0 \\
8.5\end{array}$ & $\begin{array}{r}.5 \\
3.5\end{array}$ & $\cdots$ & 0.8 & & \\
\hline & 1903 & 100 & 44. 1 & & & 2.0 & 1.01 & 13.0 & 21.0 & 20.0 & 23.0 & 15.0 & 3.0 & 1. 0 & 1.0 & & & \\
\hline Kart & | 1904 & 512 & 45.0 & & & .4 & 1.1 & 4.3 & 9.7 & 18.1 & 25.0 & 24.0 & 12.3 & 3. 9 & .2 & .4 & 0.2 & \\
\hline & 1903 & +20 & 44. 0 & & .2 & .2 & 3.31 & 13.3 & 19.3 & 17.1 & 120.9 & 14.8 & $\mid 7.1$ & $|3.3|$ & 2 & & & \\
\hline (1)ild) rit. & $100: \frac{1}{2}$ & $i 1: 2$ & $\therefore \div$ & & & & 1. .1 & 1i. 2 & [11. 3 & 16.2 & $\because 21$ & I11. 3 & 1.: 1 & $7 . .7$ & 2.5 & $\therefore$ & $\ddot{\circ}$ & \\
\hline & 1903 & 196 & 44. 9] & & & & & & 11.3 & 30,8 & 24.4 & $\mid 20.4$ & $|9.3|$ & $\mid 5.2$ & .8 & .4 & & \\
\hline Yes $13 n y$ & 1904 & 509 & 45. 5 & & & $\therefore$ & 1.2 & 3.9 & 10.6 & 15.5 & 17.4 & 21.2 & 16.6 & 8. 4 & 3.1 & 1.2 & (6) & \\
\hline & 1903 & 300 & 44. 3 & & .3 & 1.3 & 2.01 & 10. 3 & 17.6 & 21. 3 & 23. 6 & 12.6 & 6.6 & 3. 0 & $\therefore$ & & .3 & \\
\hline Noy & $\begin{array}{l}1904 \\
1903\end{array}$ & $\begin{array}{l}513 \\
100\end{array}$ & $\begin{array}{l}45.8 \\
43.8\end{array}$ & & ... & 1.0 & $\begin{array}{r}.8 \\
6.0\end{array}$ & $\begin{array}{l}3.3 \\
9.0\end{array}$ & $\begin{array}{r}8.7 \\
27.0\end{array}$ & 11.3 & 19.3 & $\begin{array}{r}18.9 \\
9.0\end{array}$ & $\begin{array}{r}19.1 \\
2.0\end{array}$ & $\begin{array}{r}11.1 \\
3.0\end{array}$ & $\begin{array}{r}4.7 \\
\ldots\end{array}$ & 1.9 & .4 & 0.2 \\
\hline
\end{tabular}


The average number of rows of scales varies from $4: 3$ to nearly 46 , with extremes 38 and 52. It was noted that the slender type form usually showed a slightly smaller number of rows.

In conclusion, it may be stated that the various counts, while not amounting to demonstration, point to similarity in fishes from a given basin rather than to a heterogeneous mixture of schools. In general the enviromment at any one locality is very like that at any other; hence if the output of each stream were entirely segregated there would scarecly arise great differences of character among the different lots. The range of variation is, in fact, so small that it appears to fall within the possible effect of the personal factor if the counts were made by different individtals; or of changing schools in any given stream if made by the same individual in sequence. With measurements, however, there is a difference. A sufficient number of fish for the purpose can be measured in a few days spent at any one locality, and the time element may be controlled by frequent change of place and renewed examinations at each. 'The remarkable difference found between the fish of such adjacent localities as Dolomi and the Moira Sound streams clearly proves the value of such data. ${ }^{a}$

\section{STREAMS NOT UTILIZED BY SOCKEYES.}

It is unfortunate in the study of Alaska salmon that almost no streams not known to be frequented by sockeyes have been examined. The only exception of importance is the Anan of Bradfield Canal, which was visited on August 31, 1905. This stream is noted as the carliest and most productive humploack stream in Southeast Alaska. It is slightly less than the Naha in volume and about 3 miles in length below the first lake. Nowhere in the course are any impediments to salmon at ordinary stages of water. The lake has about 160) feet of elevation, and on the above date had a surface temperature of $59.5^{\circ}$, about 1 degree higher than the stream. A tributary of the stream was $54^{\circ}$. At that time humploack and ling salmon in small numbers were seen, and there were a few scattering red fish which were thought to be sockeyes. Two humpbacks were seen to jump in the lake. There is no apparent reason why sockeyes should not ascend this stream in numbers equal to the runs in such streams as those of Moira Sound. An examination of the lake might reveal some obstacle to their natural propacation. There was nothing at that season apparent in the surface densities or temperatures to deflect a run entering Clarence Strait. From this strait through Ernest Sound and into Bradfielel Canal the temperatures were in general increasing, $54^{\circ}$ to $5 x^{\circ}$, and densities deereasing, 1.020 to about 1.010. In Behm

a For a similar study of the winter flatfish (Pleuronectes americanus), see Hermon (. Bumpus, On the identification of fish artificially hatched. American Naturalist, vol. xxxII, June, 1898, p. 407-412. 
Canal at the same time temperatures rose from $55^{\circ}$ at the head of Tongass Narrows to $58^{\circ}$ off Spacious Bay, densities falling from 1.0188 to 1.0124 at the same time. Subsurface tows demonstrated an abundance of plankton food throughout all the channels.

Ketchikan Creek is a larerer stream than Helm Bay Creek, which carries a few thousand sockeyes. It drains a lake and is frequented by humpbacks and cohos. No sockeyes are known to enter it. They could not reach the lake owing to falls about a mile from the mouth, but a school of fish looking for a suitable stream would learn this fact only after ascending the river.

A few hundred yards below its head Naha Bay receives a small creek known as Steelhead Creek. This creek drains lakes of considerable size, and should carry water suitable for sockeyes, though they could not enter the lakes on account of an intercepting fall. The volume is small, but during the rainy season is ample for the ascent of fish, and many coho, dog, and humpback salmon, as well as steelheads, spawn there. No sockeyes are known to enter it, nor were any sockeye fry seen among the thousands of salmon fry taken there.

It is probable that examination of the unstocked streams of Alaska would disclose others of interest in the question of stream selection.

\section{RELATION OF SIZE OF RUN TO SPAWNING AREA.}

There seems to be no relation between the size of the run at any given strean and the extent of spawning ground. Ietta, considered good for from $50,(000)$ to $150,0(0)$ fish, has comparatively lit te area of beds. The fish spawn mainly in one small creek about a mile in length, and along the lake shores. The Naha, as noted above, has a small area compared to its natural productiveness. Kegan has almost no spawning bed -only about a hundred yards of the main stream. At Nowiskay the borders of the lake are used almost entirely, none of the entering streams being suitable. Yes Bay and Karta streams both have excellent and extensive beds. On the other hand, the stream at Ward Cove has a greater area of good spawning ground than any of these streams except Karta and Yes bays, yet it yields too few sockeyes to pay for fishing. Karluk Lake has many tributary creeks that are used by spawning fish, but the total area seems scarcely commensurate with the enormous productiveness.

With the exception of the few streams just mentioned, little is known of the spawning grounds of the Alaskan sockeye. Up to 1903 no attempt was made to arrive at the natural fecundity of the spawning beds; hence the investigator is absolutely without standard or means of accurate comparison. 


\section{SELECTION OF SPAWNING GROUND.}

CONDITIONS REQUIRED BY THE SOCKEYE.

Interesting preferences are shown by the mature salmon on coming out of the lakes to spawn. The first run of sockeyes at Fortmann Ilatrhery (usually of somewhat smaller fish) enters McCune (reek. This creek is a mile or so in length and drains a slope to the southeastward of the lake, the mouth, as will be seen from the map, being but a few yards from the entrance of the main stream. The lower course is over fine gravel and has but a moderate fall.

On July 2S, 1903, Heckman Lake at the surface was 64․, Naha River at the hatchery $60^{\circ}$, McCune Creek $53^{\circ}$. There were no spawners in sight. August 27 the river was $61^{\circ}$ and the creek $5210^{\circ}$, and fish had been spawning a week. At this time some fish were showing a preference for the creek, which was fenced. Considerable numbers of ripe fish were in the river. October 15 the river was about $46^{\circ}$; November $17,36 \frac{1}{2}^{\circ}$.

Solective discrimination is also shown in Jordan Lake. Emma Creck, triblitary to that lake, has a small lake near its source in which its water is somewhat warmed. Gibson Creek, a larger stream, evilently has no expansion in its course, for its waters are always cold. Sockeyes are never known to spawn in Gibson Creek, which carries a tempreature of $45^{\circ}$ or less, while Emma Creek, between $50^{\circ}$ and $60^{\circ}$, is to a small extent made use of.

August 18, at Nowiskay, North Arm of Moira Sound, the main stream above was $51^{\circ}$, the lake over the spawning beds $62 \frac{1}{2}^{\circ}$. A few fish were in sight, but none spawning. This stream is $44^{\circ}$ and the lake $+6^{\circ}$ to $45^{\circ}$ (luring the spawning season. No sockeyes enter the strean, though dog and humpback salmon do. The sockeyes spawn about the lake shores.

At Karta Lake, September 11, Willow Creek was 50 $\frac{1}{2}$; Alder Crock, $17 ?_{2}^{\text {? }}$. Sockeyeswere spawning in both in about equal numbers, or slishtly preferring Willow Creek, perhaps for its greater size. The main river bolow the lake was $533^{10}$ and full of dog and humpback salmon.

At les Bay, September 19, 190:3, the river above was full of spawning sockeyes, temperature $50^{\circ}$; sockeyes were also entering the flooded creeks at $70^{\circ}$. September 14, 1904, the surface of the lake was $52^{\circ}$, the water over the beds, $49.5^{\circ}$; in the pool above, $48.5^{\circ}$; a feceler of this pool, $46^{\circ}$. May 2, 1905, the temperature of the main stram had reached $19^{\circ}$. Rarly in September of that vear salmon were spawning in water of $51^{\circ}$.

At Quadra, August 1, 1903, the lake surface was $63^{\circ}$ to $65^{\circ}$. Osten Creek, at the head of the lake, in which the fish spawn, $51^{\circ}$ at $3 \mathrm{p} . \mathrm{m}$.; the sockeyes had just begun to appear at this stream. A fine reek 
farther down the lake was $57^{\circ}$; it is said few sockeyes enter this. The hatehery brook was $46^{\circ}$. The bay just off the stream dugust 5 was $64^{\circ}$ at $6 \mathrm{p}$. m., or practically the same as the outflow from the lake.

At Kegan, October 3, fish were spawning in the main stream above at $47^{\circ}$ and refusing a smaller stream at $43^{\circ}$ flowing through the same mouth; later they were reported to be spawning in both, temperatures unknown, but doubtless equalized to a degree.

At Ward Cove, September 6, a few sockeyes were spawning in the stream at $55 !^{\circ}$, but this is not a sockere stream, properly speaking, though it has the required lake and an extensive stretele of erood spawning bed.

In the Wallowa Dr. Kendall observed that the dwarf sockeye preferred the warmer water after temperatures fell below 45 , though spawning continued until the temperature had dropped to $40^{\circ}$.

These observations indicate that the natural spawning temperature for the sockeye is between $47^{\circ}$ and $55^{\circ}$, probably not over $50^{\circ}$ by preference. (See p. 97.) The matural lall temumature for creeks not draining lakes or extensive swamps is about 45 to 45 . lake outlets $55^{\circ}$ to $60^{\circ}$. The presence in a stream's course of a lake of any large size and a low altitude may usually be at once discovered by temperature, except, of course, when the lake sutflow is mingled with another stream of low temperature, as from a glacier. Ordinary springs have a simmer temperature of $14^{\circ} 645^{\circ}$, winter aromend $40^{\circ}$. Creeks, of course, fall with the air temperature to freezing.

In the same manner in which they approach the ascent of a river from the sea, the sockeyes school about the spaming stream a short time before entering, and after entering the current proceed by easy stages to the bed finally occupied. Frequently they are seen to drift back orer a riffle they had almost surmomed, and appear in most cases to enter swift water with hesitation and caution. It was noted at the Fortmann Hatchery when high water prevented the usual seining of ripe fish that the natural spawning did not commence for a day or so after the fish covered the beds. A short time seems to be spent in selecting nests.

The sexes of the Maska sockeyes as found during the fishing season are approximately equal, or perhape there is more commonly a slight excess of males. Of 1,025 examined at Karta Bay June 24 to July 8, 1904, the sexes were equal; 548 of the first arrivals at Nowiskay July 14-22 had an excess of 12 males, while of 551 at this same place August 10-31 males were still in excess by 19. At Iiegan from July 24-29, ass examples showed 25 in faror of the females; Yes Bay July 26-28, 1905, had an excess of males by 10 in 510, while on August 14 among 172. fish the females exeeded by 24; August 16-20, 1904, in 976 examples there were 31 more males $10731-07-7$ 
than females. Inolomi August $4-11$ showed a surplus of 21 males in 990) at Quadra Lugust 24-29, 967 examples had an excess of 45 males. These figures show an arerage preponderance of males by 1.3 per cent. There seems to be no difference in the time of arrival of the two sexes. One sex may be more numerous on one day's fishing and the other on the following day.

It is stated that in the Fraser during the first of the run, the males are greatly in excess. The presence of unmated males is to a certain extent damaging. wince they go through the spawning movements alone, and thus disturb the beds. Under wholly natural conditions there should be practical equality in numbers of the two sexes.

\section{PREFERENCES OF THE KING SALMON.}

The king salmon spawns in higher temperatures than the sockeye. On the Ilecloud River it begins spawning at a temperature of about $56^{\circ}$, the summer run completing the season within $3^{\circ}$ or $4^{\circ}$ of that temperature. In Battle Creek the fall run sparns in practically the same range. That they habitually seck a less depressed temperature than the sockeye is shown by their spawning below the lakes inte or bevond which the latter species invariably continues. This has been noted at Karluk, on the Wallowa, and on the Salmon and Parette rivers in Jaho, though in short streams like the Tes Bay Stream the strageling ling salmon may aloo go above the first lake. But while this temperature is suitable a higher can not be endured. It has been found that the summer run can not be successfully ("onfined in lower Battle Creek. These fish naturally travel to the cooler upper reaches, and retention in the warmer water of the lower course causes their death.

At the Trocadero Aquarium it was found that fish of 3 and 4 years can not endure a summer and fall temperature of more than $61^{\circ}$; an addition of 3 or 4 degrees is fatal. Moreover, at that period an abundance of water is essential. This latter condition, perhaps, enables the fish safely to make the ascent of the heated waters of the Sacramento. During May, when the height of the summer run is passing, the river temperatures range closely about $60^{\circ}$, at which temperature the fish are alble to move at the rate of 10 miles per day. In Aumust, when the fall run is traveling up the river, the temperatures are decreasing from about $80^{\circ}$ to $74^{\circ}$. At this temperature they travel but half as fast, though at a more advanced stage of maturity. During October and November the temperatures continue to fall, varying at Sacramento (City from $70^{\circ}$ to $60^{\circ}$, and $60^{\circ}$ to $50^{\circ}$ during the respective months. At this time the spawning temperatures of $50^{\circ}$ to $55^{\circ}$ are found in the middle course of the river, and in seasons when the depth of water is suitable it is found that the salmon spawn largely on the shallows below Tehama, thus withdrawing large num- 
bers from the propacation stations of the upper river. 1 careful study of the king salmon's movements on the Columbia is much to be desired. The greater length of the river, more numerous branches, and higher latitude and altitudes make that basin an extraordinary field for research, and its very great ecomomic value demands the results.

SPAWNING ITREAMS CHOSEN BY THE COHO, DOG, AND HUMPBACK SALMON.

The coho apparently drmands a ret lower temperature for spawning than the sockeye. Where it enters lake outlets early, it presses into the hivher waters in much the same manner. It diliers in that it often selects streams not eomnected with lakes, but in all cases its later arrival from the sea funds the temperature low. While the most active of any species, long journeys do not find favor with it. Wallowa and Baker lakes seem to be at about the limit to which it travels.

In the Naha in 1903 the cohos were spawning October 27 in a temperature of $46^{\circ}$. This is probably about the temperature at which they begin. During October and later the small streams fall rapidly in temperature, so that scarcely any running water after that date moull be too warm for spawing purposes. Since ia farorable places the coho continues spawning throughout most of the winter, any temperature above freezing does not seem to be prohibitive. At Heta it is reported that the cohos sometimes spawn in small numbers throughout the winter, even as late as March. This lake is said to have areas of open water, perhaps due to warm springs, about which sockeyes spawn until February. Alexander (ms. notes) states that in the winter of $1902-?)$, while the lakes and stream were frozen over, one of the lakes of South Olga stram, Karliak Island, was visited by a party of white men and Indians who found a large number of sockeyes and cohos frozen in the ice. These were thought to be late-run fish entering after the canneries had closed. Many carcasses of salmon that had been frozen in the ice were seen by Rutter at Karluk Lake in the spring of 190:3. In that stream the oceurrence at times of late runs arriving after the usual closing time of the cannery arly in September is well known. They more frequently oceur in seasons of a small early rum, and at such times the cannery is held open for them. The carcasses of winter spawners were still to be seen on Trail Creek the last of May, 1904.

The $\log$ and humplack salmons apparently exereise less diserimination than other species. The humploack was noted as working upstream in the Naha at $61^{\circ}$ August 25, 19(1), and in the Anan at $55^{\circ}$ August 30, 1904; yet it had completed spawning in the outlet of Yes Lake September 11, 19(05, in temperatures around 56 . Karta River, September 12, 1903, was full of both (log and humpback sal- 
mon sparning at a temperature of ojt, and steclhead Creek contained many spawning humploake dugust 25, 1909, at about the same temperature. It is probable that the optimum temperature for the humplatek is about the same as for the king. The dog salmon seems. to accept a slightly lower degree; a few were spawning in a creek of Moira Sound as early as August 18 in $48^{\circ}$.

\section{NATURF OF SPAWNING BEDS SELECTED.}

With the exception of the coho, the salmons appear to require a depth of water and a fineness of bed material somewhat in correspondence with their relative size. The kins salmon spams in water of a depth up to 2 or 3 feet, with a bottom of gravel and coarse sand. No exact conditions seem to be required. In the Salmon River, Idaho, the kings are reported to avoid the coarser gravel and swift currents; in the Sacramento they will spawn on bowldery rapids.

The sockeye aflects shallower water for spawning than the king. On most Mlakin beds many oceupy water which does not completely cover the male fish. In the selection of spawning beds this species is unique in requiring the adjacency of a lake; also it is the only specoles of the wenus that erer spawns in still water. The lake shores chosen are more frepuently portions thenew which a small rill flows or where seepage comes through, but sockeyes are known to spawn where no inflow of any kind is apparent.

In the streams the beds chosen are similar to those well known for various species, but, as mentioned above, in water of less depth than is usual for the kine. Sometimes bottoms of fine crravel are oceupied, sometimes bottoms of larger bowlders where the current is so swift as to make the holding of position precarious. No observations are recorded as to whether the first comers occupy the more accessible croumels. They apparent!y distribute from the begiming, and there

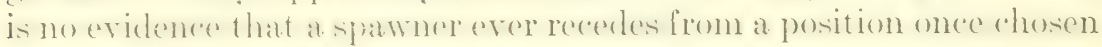
and occupied. Unless carried out by the current, even the spawnedout fish remain motil ther die about the pool where they have spawned. It Yes Bar stream in 1!30:3 fish could be found throughout the stream as far as the falls, but stikingly few examples were attempting to pass higher. The writer has seen no fish attempt the dam on the Naha just above the spawning beds, though cohos are said to do so. A few inclivisluak usually (nter all the small unsuitable brouks duringer times of freshets, apparantly leturning with the subsidenee wi the water.

In the Karluk tribitaries many fish oceupy beds where none of the material is of a size they an move, hence the naked exges are swept down the current and doubtless most of them lost. In bottoms of

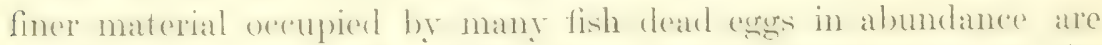
usually to be seen in the edelies behind the hillocks formed by the spawners working up the gravel. 
The coho, perhaps in its effort to reach low temperatures, frequently continues up the small streams to a point where the bottom material is coarse. In Steelhead Creek it passes humpbacks and dogs on the gravelly lower part of the stream and spawns in the rough upper portions. In all the small Alaskan streams it doubtless occupies the sockeye beds later in the season and perhaps does some damage, but the greater part of the run spawns below those beds and in creeks not entered by the sockeyes. Cohos, like the smaller species, while making their way upstream or when frightened out of the "nest," may frequently be seen in water too shallow to rover them. Whether these "nests" are excavated in shallows where the original depth is less than that of the fish, or whether the small amount of water is not more usually due to a fall in the stream subsequent to the fish's entry, has not been fully ascertained.

Humplack and dog salmon may often be seen spawning on the same beds, but in general the former is more frequently seen on finer bottoms and in shallower water, while the more powerful dog salmon sometimes occupies bottoms of coarse gravel in some depth of water. The humpback is said sometimes to fail to get beyond the reach of high tide in the selection of its spawning place.

\section{DEPOSIT OF EGGS.}

The deposit of spawn on riffles and in small streams, where it is most subject to the action of floods and frost, at first sight seems to be poor economy. But the necessities are twofold, first, aeration, and second, protection from light and enemies. In water of mueh depth relative to volume the bottom current is retarded, with the result that fine sediment is deposited and the circulation through the gravel or other material is impeded if not entirely cut off. If the egegs were placed in such a region of little current, they would not be arried from under the mother fish and the material for covering and protecting them would not be carried down over them, hence any such movement as the spawning fish now makes would only lead to stirring up egges and gravel, with the result of destroying the first spawn within a few days after its deposit. For this reason the lake spawning of the sockeye must be of less proportionate value.

The action of the spawning fish in breaking aw ay the gravel by means of foreing the body and tail against it achieves the double purpose of working the sex product down to the genital opening and of setting the fine gravel and sand in motion to cover the exges. When first extruded the contents of the egrg envelope do not quite fill it, the egg is soft and will bear considerable rough handling. Its specific gravity, only slightly greater tham the water, holds it to the bottom, but allows it readily to drift along with the current. Upon finding an early lodgment the osmotic absorption of water "freezes" it to the object against which it rests, and any drifting particles of sand not heavy 
enough to distodge it readily cover and conceal it from the light. It is probalile that the dead exgers referred to above as seen in abundance about a well-covered ground are as often the earlier deposits due up by later arrivals as eggs that have failed to be covered. Live eggs are almost never seen among these, as should be the case if they are of recent deposit. Ineovered eages must "rentually perish by the light eren if not ronsumed by exon-eating fishes and birds. In ordinary currents the eggs drift perhaps but a few feet. Very early the ridge below the "nest "rises to a height that reates a bottom celdy, causing the downward motion of the eggs to cease on its lower slope. For this reason when wne of these ridges is opened the erreater number of eggs ordinarily is found in its lower portion.

During the season of spawning a well-covered ground becomes thrown, through the joint antion of the fish and the current, into high ridges, or hillocks, sometimes as much as $2 \frac{1}{2}$ feet above the corresponding depresions or holes. Egors may usually be foumd bured in

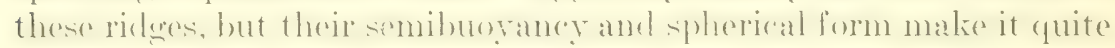
difficult in a current to recover them without a screen. The abundance of dead eggs which at times collects in the eddies below these ridges has been mentioned above. On Karluk Lake in 1903, in the creek on which the spawners were counted, these beds were examined by digging in the gravel to find the condition of the deposited eggs. Between August 5 and September 2, 58 "nests" were so examined. In these were found 4,005 good eggs and 2,022 dead ones, or, in other words, about two-thirds of the buried eggs were found to be in good condition. On the latter date 587 eyed eggs were found under about 10 inches of gravel, with only 13 dead ones. This demonstrates that eggs will live and develop under proper conditions when deeply buried. In another stream, in the center of a nest, under 6 inches of gravel, only 29 of $620 \mathrm{eggs}$ recovered were living. In a third bed of $1,140 \mathrm{cggs}$ taken from the lower half of the nest, in a light current and from under 7 inches of gravel, only 28 were dead. In general, the observer records few eggs from locations in strong current; this was possibly in part from failure to find the eggs as well as from their scarcity. Nost beds show a decided balance in favor of the good eggs. In two examinations of the connecting stream from one of the tributary lakes less than 4 per cent of the eggs were dead.

\section{CONIPLETENESS OF SPAWNING.}

In 1903 a careful count was kept of the sockeyes spawning in one stream of karluk Lake, the second frem the outlet on the right or east side. This is a small creek, averaging some 10 feet in width, about 1 mile of which is used for spawning beds. From August 5 to September 5 of that year, 21,756 spawned fish were examined in this creek, presumably the total number spawning there in that time and practically the total for the season. Of these, males were in excess by 
about 3 per cent, the numbers being 10,72:3 fermales and 11,03:3 males. But one unspamed female was foumd dead. Deat unspawned males are more common. Of 636 fomales opened, abut sol per cent were entirely spawned out, i. e., with no loose egors in the ahdominal cavity; the remaining 20 per eent had an average of 17 egres mopamed, with the most in any instance noted 1,246. The sockeye carries between 2,500 and 4,000 eggs, an average, perhaps, of about 3,500. This remnant, then, amounts to about one-half of 1 per cent of the total number of eggs matured. The product of this one stream on the same basis of estimate is $37,000,000$ egres. It is believed that less than one-tenth the number of fish entering the lake spawned in the above-

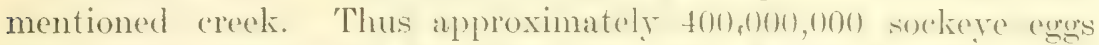
were spawned in Karluk Lake basin in 190);. Sorkeves are reported by natives to spawn late in the winter, even under the ice, but it is doubtful whether it is usual for any notrworthy number to orecur as at fall run, as with other species and in more southerly streams.

In 1903 the spawning scason was practically over carly in weptember. Since the fishing continues ordinarily into that month, the spawning should last much later. The double pperation of amnery and hatchery, perhaps, aceounts for its early dofe. On the Nahat the season continues into November. At Hetta the fish are reported to spawn in small numbers until later in the winter.

\section{PERCENTAGE OF NATURAL PRODUCTION.}

The percentage of natural production of fry is a matter of the utmost interest. Tn daylight observation of a well-populated spawning ground one is sometimes struck by the absence of factors to cause damage. At Yes Bay, Karta Bay, Kegan, the Naha, Wards Cove, and other places one may see hundreds of various species spawning uninterruptedly. At times on the humploack beds where fish are numerous the dead exes lie in numbers in the edelies for days and "ren weoks untouched, not a trout or sculpin in sight -though it is certain that at least a few are in protected places near by. The ducks arrive late after most of the spawning in that recion is over. It is believed by the writer that the natural loss of spawn has been overestimated.

In Steelhead Creek in 1903 comparatively few cohos were noted-

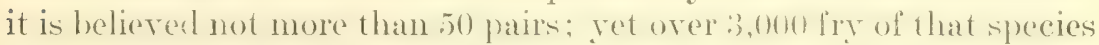
were sometimes taken in a single night as they were leaving for the sea. The run begins early in May and lasts until July. In six sets of the net in May and June an average of about 1,300 of these fry were taken, which indicates a run of between 50.000 and 75,000 for the season, or a product of at least 30 per cent. Similar facts recarding steelheads were noted in the same creek, which was observed carefully in both 190:3 and 1904 for spawning strelloads in an effort to take suflicient egers for·an experiment. Not orer a rozen pairs rould 
be seen either season, yet early in July the fry were migrating at the rate of 2006 to 300 per night and the creek was full of them till the fall rains swept them out.

Recardine the migration of sockere young from secten Later in 190:3, Baberek states: "Ther sight was amazing, and impressed one with the fact that the perentage of natural fertilization of ovat and the survival of the resulting fry was greater than has been generally believed by the authorities."

It will be noted that eyed eggs were found in the Karluk creeks on September 2. On this date the lake surface was $44^{\circ}$, having fallen about $10^{\circ}$ in as many days. With the shortening of the days and prevalent cloudy weather the temperatures must fall rapidly from this date, and it is questionable whether any but the earliest deposited and hence most advanced eggrs hatch before the onset of freezing weather.

Fry were found as late as August 1 in the stream just below the lake; species midentified. It is improbable that any considerable number of sockeye eggs hatch in time for the young to seek the shelter of the lake for the winter. With the congealing of the waters in the mountains the streams will become reduced in volume and the entire bed must at times become frozen over, part by its exposure and the remainder by the formation of anchor ice. The habit of the lish of spawning on the shallow riflles must manailingly subject the spawn to this influence. That it is not an exterminating influenere is due to the covering of gravel which the egros have received. The depth to which the bared beds freeze in winter has not been ascertained. At points where a constant current percolates through, such as must occur on the spawning riffles, it is improbable that this depth is so great as minht be suspected in view of the low air temperatures.

The effects of freshets are laregely nullified by the season at which they occur. Late fall rains produce comparatively small floods for the reason that the precipitation in the hills falls as snow. The spring flowels which rome with the melting snows will fincl the egrgs in great part hatched, and fry are largely able to rise above the deposit.

\section{RELATION OF SPAWNING HABITS TO NUMBER OF FISH.}

The spawning habits of a species bear a suggestive relation to its abundanee. The humphate in southeast daskat far ontmumbers all others. This is a region of small streams, and practically all that have a suitable bed and are accessible from the sea are utilized by this salmon. The small size of the adult humpback makes spawning possible in even shallower water than the sockeye or coho requires. The number of eggs, about 2,000 , is perhaps less than in other speecies. The inculation period is less. than that of the sock- 
eye or king. This, with the early arrival on the beds and consequent high temperature of the incubating water, lrings the humpback ege to a hardy stage early in the season and the fry to a stage of development that sends them seaward with the opening of spring. The small size and light color of the erge also may be arlvantageous. In regions of larger rivers, such as Bristol Bay, the number of humpbacks is much less in proportion to other species. The same is true for more southerly regions. In the Bristol Bay region the arerage size of humplatelis is considerably less than in Southeast Alaska. Whether these facts are due to the character of the streams can only be surmised.

The limited number of cohos can not be attributed to scarcity of spawning beds of the nature required. These are scarcely less widely distributed than those suitable for the humpback. The spawn incubates in about the same time, but is somewhat larger and more brightly colored. The increased number of egoss, about :3,000, should offset the disadvantage of size. The cohos coming last to the heds, their exgs are undisturbed by other fishes, but since much of the spawning is late the loss from physical canses may be greater. The fry are probably less active, reach the sea later in the season, and perhaps suffer greater loss from predatory enemies.

The $\log ^{\circ}$ salmon, while widely scattered, occurs in numbers only in selected streams. The eggrs are very large, rather light colored, and run about 3,000 to the fish. The incubation period probably differs little from that of the humpback. The fry reach the sea early, and there is no obvious reason why this should be one of the scarcer species.

The spawning habits of both king and sockeye are obviously advantageous. The king, resorting to large rivers, is able by its strength to reach waters where the conditions are most favorable. ()ther species do not work orer its beds; and though limited in the main trunks entered, the king secures extent of territory in the numerous branches; the habits of the young permit them to obtain the necessary food in the streams, and the distance of the trip to be performed insures their sufficient age and size for aderuate protection upon reaching the sea and its rapacious inhabitants. The summer resilence conserves the species to an extent, while the migration of the main body as fry prevents overpopulation of the limited freshwater area. In this connection it is of interest to note that the fish found in the Columbia headwaters in 1895 were of less than the arerage size for that stream, weighing only 10 to 14 poumds. Even allowing for tissue expenditure during the ascent of the stream this does not indicate that the stronger fish travel farthest, but rather the contrary. It seems possible that at a certain point the beds are occupied by the stronger fish and that the less powerful go beyond in search of unpreempted grounds. 
The sockeye profits by its lake habit. An unocenpied food supply is thus made available, and protection for the immateme young is obtained in waters not naturally inhabited by many predaceous animals. In basins of large productiveness the overflow of fry, migrating as such, conserves the lake food supply. In the main the spectes secures inmonity from disturbance on the spawning berls, passing beyomel all but eoho and king and avoiding the latter by selection of colder water.

\section{CHANGES INCIDENT TO MATURATION.}

The changes that are associated with maturation of the reproductive element vary in extent in the sexes, in the species, and with the age The production of the jaws and growth of canine teeth that is more or less characteristic of all male salmons is seen also in the trout and the charr. The change in body form-the increase in depth by the ridging of the back-is much more developed in the salmon. The changes seem to be ereater in the larger, and presumably older, fish. The errilse of the king shew very little of it, seareely more than the female, and in the "are of fingerlings in the Sacramento which develop mature spermatozoa there is no evident external change.

In the trout and charr the upper jaw elongates somewhat but does not become hooked. The lower jaw elongates and becomes knobbed or hooked; this swolling is ustually received in a corresponding recess or notch in the upper jaw, but sometimes is sufficiently large to prevent complete chosure of the mouth. After the spamning season is over these growths are to an extent resorbed, but the jaws never fully recover their original shape.

In the sacramente the king salmon of the spring run show none of these characters until some time after entering the fresh water. The late runs, being more developed, show some changes by the time they have reached the mouth of the river in Suisun Bay. The various changes, which have been fully described by Ruter, are progressive with the derelopment of the reproductive clements. Little of the red color is shown by this species exeept in the large (old!) males, and even in these never approaches the brilliancy of the sockere or coho. Neither do they as fully develop the body depth as speceies which frequent shallower waters.

The Alakkin sockere at the time it is first taken in the fisheries has already begun to show the hooked jaw, so that with care one can distinguish the sexes in the larger fish. Cases will oceur, however, in which the female has jaws somewhat prolonged, and there are corresponding cases of males with neat heads, so that in statistical work it is essential that the fish be opened to make sure of the sex. Late in the seatson, or in occasional schools at any time, the males are more readily distinguishable. 
When the sockeyes emerge from the lake en route to the spawning beds the change has become complete. The entire fish, except the head and fins, has changed from its original green and silver to a brilliant vermilion or maroon. The head retains its bright green color and the fins become variously dark. It this time the sockeye rivals the tropical fishes in beauty of coloration. The elongation of jaws and devalopment of depth are extreme in large males; the females show little of it and acquire less brilliance of color, in some cases scarcely any.

The grilse (Aretic salmon) exhibit less change than tho large fish, but show all the characters to a degree.

The dwarf sockeye exhibits very little change; sex of ripe fish taken in Wallowa Lake can not be distinguished by external appearance. At the time of entering streams for spawning they are thus described by Kendall:

Back olive green, more or less spotted with black; dorsal and caudal somewhat spotted; sides dusky metallic blue or smoky with faint marks like parr marks; belly white or slightly dusky. Pectorals, ventrals, and anal black, tipped with white; outer ray of pectorals white; a general brassy luster after the fish has been out of water some time.

Color's, spotting, etc., vary in different indiriduals, but there is never any red. In Alturas Lake in larger examples of the dwarf the red is sometimes present and the other changes are somewhat more marked.

The coho shows more change in the female than any other species, and the jaw develops more knob, as in the trout. It is sometimes difficult to distinguish the sexes among spawning fishes in the Nahn. Both may acquire a red almost as brilliant as the sockeye's, so that in the water it is easy to mistake either species for the other.

The extreme height of the back in the male of the humploack and the characteristic color blotching of it and of the dog salmon are well known. The females of the two species, particularly the latter, retain silvery colors and neat forms more fully than other species.

The useful purpose, if any, which these changes subserve is difficult to surmise. It may easily be believed that the development of teeth, and of jaws to render them eflective, is a matter of defense with the male. It does not hesitate to make use of the weapon to drive away intruders, but its awkward and slow movements render its armature of no avail so far as trout and other egg-eating fish are concerned. The only service is in preventing other males of the same species from mating with the female, and even in this the ability is not always equal to the emergeney. A small actire male has been seen to slip alongside a spawning female during the absence of her consort in pursuit of another interloper and administer all the attention shown by her regular attendant. In general it may be assumed that in this man- 
ner nature secures the offspring of the well-developed mature males, which ofispring is known to be stronger and more thrifty than that of the younger fish.

The exhibition of beauty in color and form in the male, which has been thought to be the result of sex selection, ean hardly be so considered in the case of these fish. The female apparently has no option in the matter. The larger male will drive away the smaller and take possession. The peruliar compression of the male, with the flattening of the ventral aspece, increases its ablitity to work through the shallow water, which the small size of the female, without such change, allows it to enter.

\section{RETURN OF ADULTS TO SALT WATER.}

To test the question of the return of salmon to salt water after once entering a river system, Rutter, in 1903, made two experiments. Eight hundred salmon (npecies not noted, but probably mainly if not all sockeyes) were tagraed and released in Karluk Lagoon (brackish water) 1 mile from the sea. Four hundred of these were released June 12 and 15. One was retaken outside in a cannery seine 1 hour after release, 3 were retaken entering Karluk Lake after 11, 13, and :3t days, respectively; 2 were retaken by seines in the lagoon, and 1 died in the lagoun. Doubtless many of the tage were lost, and perhaps many fish entered the lakes or were retaken outside and unobserved.

Five hundred and fourteen were tagged and released on June 30. One of these was retaken in New Red (Ayakulik) River, 40 miles down the coast, 3 datys later. One reached the lake in 10 days; another was found spawning there August 2; one was seined in the lagoon 2 dars after release: and another, a creen female somewhat fungused and worn, 27 days after. No others were reported.

This experiment is very incomplete and most desirable data are lacking, erpecially as to whether the fish were taken into the lagoon in a live car or were seined in the lagoon after voluntary entrance. The influence of the tag, clamped to the lower jaw by a strong ring, in irritating the fish and stimulating unnatural action can not be estimated. The results point to the probability that sume fish remain in the lagoon for several days, some reenter the ocean, and others spend varring times somewhere between the lagoon and lake.

Another experiment was the tagging of 255 individuals at the mouth of the lake, from July 3 to 25 . Of these, 123 were males, 64 of which were ripe and bif showing more or less of decar, fungus, ete.: 132 were females, 23 ripe, and 70 in porr conclition. These fish were taken in a trap built at the outlet of the lake, but on the shallow or small current side. This location unfortunately led to the securing of a large perentage of weak fish, and marle the results less valuable. In gemeral, fish reach the lakes in somel condition. Of these tagged 
fish, 3 females and 1 male were retaken in the ocean by the camnery seines in from three to eleven days after tagging, 1 was retaken in the trap the following day, and 2 males were found in the spawning creeks.

The main interest attaching to this result is in the number of ripe fish obtained at the entrance to the lake. The percentage of ripe fish in the number trapped is of no point, sine the stronge gareen fish entered in the heary current beyond the trap. It may be that these fish were hindered from making an early ascent of the river by the seining carried on for the cannery, and that such a conclition of ripeness is unnatural. If there is no purpose in a lake residence of about one month it is difficult to see how it should have been brought to be the normal habit. That these exceptions were abmormalities is shown by the failure to find any of these tagoed fish in the nearly 22,000 spawned fish examined at a creek which these ripe fish would most naturally seek, the nearest good ground about the lake.

The main body of fish entering Karluk Lake came in against the stronger current and in the deeper water. During the day they entered in small schools of 20 to 60 or more, at intervals of a minute or less. They seemed to linger about the foot of the lake some days.

\section{ENEMIES OF YOUNG SALMON.}

In the trap at the mouth of Karluk Lake in 190:3, 190 charrs were taken between June 5 and July 25. The biggest catch (20) was made on June 5, after which the number fell off rapidly. The next highest catch was mate June 26 , about ten days after the arrival of the first salmon. On the 27 th a charr of $535 \mathrm{~mm}$. length was taken with salnon egoge in its stomach. On July 1 a steelhead, also containing salmon eggss, was talien. One hundred and fifty-seven, or about 82 per cent, of the stomachs were emptr; 14 , or $7 \frac{1}{2}$ per cent, contained remains of fish, mostly cottoids; 13 , or 7 per cent, contained insects or their larvæ; 6 , or over 3 per cent, contained mollusks, snails, and clams; 3 in adition had caten exgs, 2 salmon eggs, and the third those of some small fish.

It will be observed that these fish were taken in an "upstream" trap into which the fish would come from the river. In the river at this time were numerous schools of salmon fry and small fingerlings, get there is no record that any stomach contained a single identifiable young salmon.

During May and June many of these trout (?) were seen jumping near the foot of the lake. On the first day the trap was installed, May 29, 10 were taken; on the 31st, 9, etc. No young salmon are reported in these. Epon the occupation of the spawning beds by the salmon the trout follow to feed on their spawn. This probahly forms a large part of their food until late in the season, when the maggots from the flies breeding in the deat salmon become more common. 
On dugust 19, 1:31 charre were taken in a seine haul in a spawning creek. One hundred and twenty-eight of these were feeding on maggots; 3 contained insects, and 1 a cottoid; 54 were without salmon exws hut the remaining 75 containerl from 1 to 110 ecress each, an average of 16. At this time there were few live spawning salmon in the creek, and few dead eggs in sight in the eddies, where earlier there had been an abundance. The trout were more numerous than at any previous time, in schools of 30 to 50 as well as many isolated individuals.

In the salt water about Farluk Beach they were even more abundant than in the lake. Sometimes as many as 2,000 are taken in a single haul, aud ordinarily at least jo(). No eflort is made to destroy them. July 20, 220 of these were examined for stomach contents. The most common food was small crustaceans of several species, next in abundance sand launces, both atult and half grown being quite common; youme coll were foumd in many, 40 being taken from one stomach. No other fish were found. July 25, of 22 examples, 7 to 18 inches in length, from the hatchery corral (fresh water), 17 were feeding; 2 had salmon erges, 1 had i) 2-inch salmon fingerlings, others had various crustaceans. (of 19 examples, 10 to 20 inches in leneth, from the lagoon, examined July 25, only + were feeding. One had exws, 1 marrots, 1 young sand launces, and the other some unidentifiable fish. No rainbow or cutthroat trout were seen in Karluk Lake.

July 14, 190:3, the stomachs of 28 rainbow trout, 2 cutthroat, and 2 charrs, taken in the Naha, were examined. None contained roung salmon; 1 containerl small egers like herring exese and all the rest contained only cadclis larvat. The fish raneed from '2 feet to about 8 inches in lenetle. At that time of vear many coho young are resident in the river.

During the smmmer of 190:) many trout of the three species from Ies River were examined. No record was kept of the number, hut it amounts to at least a hundred. In these the food was mainly caddis and inserets from the surface. No young salmon were found, though coho young were present in the stream.

Trout and charrs have been taken near the hatchery at the head of IIeckman Iake with numbers of fry in their stomachs. The exact conclitions are not known. In the planting of laroe numbers of fry or small fingerings, some are sure to be at least for a time clisabled and numbers can readily be captured by an active fish. The loss is apt to be especeially large if the plant is made in a vicinity where bar eggs have been dimped, and the waters thus "baited."

The sculpin or bullheal would seem to be a more dangerous enemy to the salmon fry than is the trout. It lurks under the stones in just such places as the fry will seek for shelter. Its movements are extremely rapid and its appetite insatiable. 
Ducks are perhaps the most active enemy of the salmon in Alakkat especially the sawhill (Iferganser) and golden ere (Clangutu). All ducks will doubtless root up the beds in low water, but those just mentioned, as well as the harlequin (ITistrioniens) and the gulls and terns, will dive for egors. The sawhill is resident in southeast dlaska, where the young arrive in time to feed on the colno fry but rather too late for others. In the fall the birks work with the spawning salmon. diving for the egges as they are extructed or expersed hy the shifting of the gravel. Mallards feed more on the blowfly magents in the deant fish, but apparently find a suffieient number of ergesto min the flaror of their flesh for the lable. The lareer flocks of clucks arrive rather late in the season in the Loring district, doing greatest damage to the coho in large streams, but a considerable number arrive in time for the earlier species of salmon. They do not seem to frequent the small streams, except those tributary to lakes. The grebe family does not seem ordinarily to take young salmon.

\section{GEOGRAPHICAL GLOSSARY.}

Following is a list of the geographical names used in this report, with approximate position of the places. The ast ronomical position is geiven of rivers and hays for their menthis of islands for the centere of straits for the center or the more prominent mouth or enmecting end. Admiralty Inlet, waters between Whidby Island and the mainland to the westward. $48^{\circ}$ N., $122^{\circ} 40^{\prime} \mathrm{N}^{\circ}$.

Alder Creek, one of two main tributaries entering at the head of upper Karta Lake.

Alert Bay, small bight on south side of Cormorant Island north of Vancouver Island $50^{\circ} 35^{\prime} \mathrm{N} ., 126^{\circ} 57^{\prime} \mathrm{W}$.

Aleutian Islands, chain of islands on the south of Bering Sea.

Alturas Lake, small lake of the Columbia Basin, tributary to Salmon River, central Idaho. $43^{\circ} 55^{\prime} \mathrm{N} ., 114^{\circ} 51^{\prime} \mathrm{W}$.

Anan Stream, stream emptying into Bradfield Canal from the south. $56^{\circ} 12^{\prime} \mathrm{N} ., 131^{\circ}$ $49^{\prime} \mathrm{W}$.

Annette Island, small island south of Revillagigedo Island. $55^{\circ} 08^{\prime} \mathrm{N}, 131^{\circ} 30^{\prime} \mathrm{W}$.

Baird, U. S. hatchery on the McCloud River, northern California.

Baker Lake, small lake in northern Washington, tributary to the Skagit River. Location of United States hatchery. $48^{\circ} 44^{\prime} \mathrm{N}, 121^{\circ} 37^{\prime} \mathrm{W}$.

Bartlctt Bay, small bight off east side of Glacier Bay. $58^{\circ} 27^{\prime}$ N., $135^{\circ} 53^{\prime} \mathrm{W}$.

Battle Creck, tributary of the Sacramento River, northem California.

Behm Canal, channel separating Revillagigedo Island from Cleveland Peninsula on the west and the mainland on the east.

Bering Island, largest of the Komandorski group.

Boca de Quadra, long, narrow fiord in the mainland south of Revillagigedo Island. $55^{\circ} 05^{\prime} \mathrm{N}, 131^{\circ} \mathrm{W}$.

Bradfield Canal, deep fiord in the mainland above Cleveland Peninsula. $55^{\circ} 11^{\prime} \mathrm{N}$, $132^{\circ} \mathrm{W}$.

Bristo? Bay, large bay north of Alaska Peninsula. $58^{\circ} \mathrm{N} ., 159^{\circ} \mathrm{W}$.

Cape Caamano, south point of Cleveland Peninsula. $55^{\circ} 30^{\prime} \mathrm{N} ., 131^{\circ} 58^{\prime} \mathrm{W}$.

Cape Chacon, south point of Prince of Wales Island. $54^{\circ} 42^{\prime} \mathrm{N}$., $132^{\circ} 01^{\prime} \mathrm{W}$.

Carroll Inlet, long, narrow inlet in southern part of Revillagigedo Island. $55^{\circ} 20^{\prime} \mathrm{N}$., $131^{\circ} 128^{\prime} \mathrm{W}$.

Chinook River, small tributary of the Columbia near its mouth. $46^{\circ} 18^{\prime} \mathrm{N}$., $123^{\circ} 58^{\prime} \mathrm{W}$. 
Clackamas River, tributary of the Willamette, Oregon; site of United States hatchery. Clarence Strait, main channel east of Prince of Wales Island.

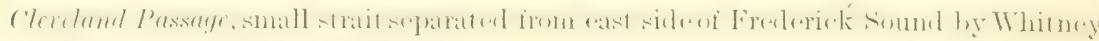
Island. $57^{\circ} 14^{\prime} \mathrm{N}, 133^{\circ} 30^{\prime} \mathrm{W}$.

Cleveland Peninsula, extension of the mainland northwest of Revillagigedo Island. $55^{\circ} 45^{\prime} \mathrm{N} ., 132^{\circ} \mathrm{W}$.

Columbia River, large river between Washington and Oregon.

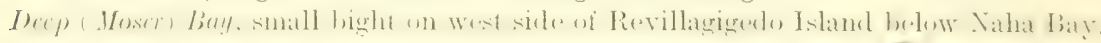
$55^{\circ} 34^{\prime}$ N., $131^{\circ} 39^{\prime} \mathrm{W}$.

Dixon Entrance, waters between Queen Charlotte Islands and Alaska. $5.4^{\circ} 30^{\prime} \mathrm{N}$., $133^{\circ} \mathrm{W}$.

Dolomi, village on east side of Prince of Wales Island just north of Moira Sound. $55^{\circ} 08^{\prime}$ N., $132^{\prime} 03^{\prime} \mathrm{W}$.

Dorr Falls, falls on the Naha above Roosevelt Lagoon. See map.

Dundes Bay, small bay off Cross Sound to the northward. $58^{\circ} 25^{\prime} \mathrm{N}$., $136^{\circ} 12^{\prime} \mathrm{W}$.

Emma Creck, small creek falling into Jordan Lake. See map.

Ernest Sound, waters northwest of Cleveland Peninsula, opening into Clarence Strait. $55^{\circ} 50^{\prime} \mathrm{N} ., 132^{\circ} 15^{\prime} \mathrm{WW}$.

Flume Creek, small creek near Loring. See map.

Fortmann Hatchery, Alaska Packers' Association hatchery on Heckman Lake. See map.

Fraser River, largest river of British ('olumbia. $49^{\circ} 06^{\prime}$ N., $123^{\circ} 08^{\prime} \mathrm{W}$.

Gibson Creek, small creek falling into Jordan Lake. See map.

Harvester Island, island in mouth of Uyak Bay, Kodiak Island.

Hcckman Lake, second fresh-water lake of the Naha system. See map.

Helm Bay Creek, stream in southern part of Cleveland Peninsula. $55^{\circ} 38^{\prime} \mathrm{N}$., $131^{\circ} 58^{\prime} \mathrm{KF}$.

Hetta, an inlet, lake, and stream on west side of Prince of Wales Island. $55^{\circ} 08^{\prime} \mathrm{N}$. $132^{\circ} 36^{\prime} \mathrm{W}$.

Hirsch Rapids, tidal rapids at head of Naha Bay. See map.

Humboldt Harbor, small bight on west side of Popof Island, Shumagin group. $55^{\circ} 20^{\prime}$ N., $160^{\circ} 32^{\prime} \mathrm{W}$ :

Isanotski Strait, water separating Unimak Island from Alaska Peninsula. $54^{\circ} 53^{\prime}$ N., $163^{\circ} 23^{\prime} \mathrm{IV}$.

Jordan Lake, first fresh-water lake of the Naha system. See map.

Juan de Fuca Strait, waters between Vancouver Island and Washington, connecting Puget Sound with the Pacific Ocean. $48^{\circ} 30^{\prime}$ N., $124^{\circ} 40^{\prime}$ IV.

Junecu, town on mainland, northern part of Southeast Alaska. $58^{\circ} 18^{\prime} \mathrm{N}$., $134^{\circ} 24^{\prime} \mathrm{W}$.

Karluk, village on west side Kodiak Island. $57^{\circ} 35^{\prime} \mathrm{N}$., $154^{\circ} 18^{\prime} \mathrm{W}$. The bay, lagoon, river, and lake adjacent of same name.

Karta Bay, small bight at head of Kasaan Bay. $55^{\circ} 35^{\prime} \mathrm{N} ., 132^{\circ} 34^{\prime} \mathrm{W}$. River and lakes of same name.

Kasaan Bay, inlet on east side of Prince of Wales Island. $55^{\circ} 25^{\prime} \mathrm{N} ., 132^{\circ} 10^{\prime} \mathrm{W}^{\prime}$.

Kegan, small stream, lake, and bight opening into Moira Sound. $55^{\circ} 01^{\prime} \mathrm{N}$, $132^{\circ} 10^{\prime} \mathrm{W}$.

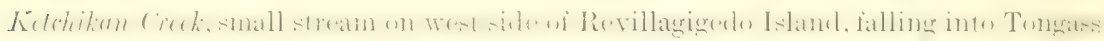
Narrows. $55^{\circ} 21^{\prime} \mathrm{N}, 131^{\circ} 38^{\prime} \mathrm{WW}$. Town of same name.

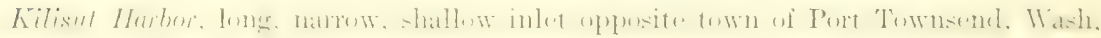
$48^{\circ} 01^{\prime} \mathrm{N} ., 122^{\circ} 43^{\prime} \mathrm{WT}$

Killisnoo, village on west side of Admiralty Island. $57^{\circ} 28^{\prime} \mathrm{N} ., 134^{\circ} 34^{\prime} \mathrm{W}$.

Kiska Island, one of the Aleutian Islands. $52^{\circ} \mathrm{N}$., $178^{\circ} 30^{\prime} \mathrm{W}$.

Klawak, village, stream, and lake on west side Prince of Wales Island. $55^{\circ} 33^{\prime} \mathrm{N}$., $133^{\circ} 07^{\prime} \mathrm{IV}$.

Kodiak, village on east side of Kodiak Island. $57^{\circ} 4 \mathrm{~S}^{\prime} \mathrm{N}, 152^{\circ} 24^{\prime} \mathrm{W}$.

Kodiak Istand, large island on west side of the Gulf of Alaska. $57^{\circ} 30^{\prime} \mathrm{N}$., $153^{\circ} 30^{\prime} \mathrm{W}$. Komandorskis, group of islands east of Kamchatka. $55^{\circ} \mathrm{N} ., 174^{\circ} \mathrm{W}$.

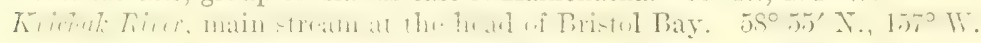


Lake Creek, the outlet of Seaton Lake, British Columbia.

Larsen Cove (or Bay), bight off west side of Uyak Bay. $57^{\circ} 33^{\prime} \mathrm{N} ., 153^{\circ} 53^{\prime} \mathrm{W}$.

Loring, village on Naha Bay, Revillagigedo Island. $55^{\circ} 36^{\prime} \mathrm{N}$., $131^{\circ} 38^{\prime} \mathrm{W}$. See map. Lytton, town of British Columbia at the junction of the Thompson with the Fraser.

Mare Island, island in north part of San Pablo Bay, California. $38^{\circ} 04^{\prime} \mathrm{N} ., 122^{\circ} 16^{\prime} \mathrm{W}$.

IICCloud River, tributary of the Sacramento (Pit) in northern California. $40^{\circ} 45^{\prime} \mathrm{N}$., $122^{\circ} 20^{\prime} \mathrm{WV}$.

Mc Cune Crcek, small stream falling into head of Heckman Lake. See map.

Metlakatla, village on west side of Annette Island. $55^{\circ} 08^{\prime} \mathrm{N} ., 131^{\circ} 34^{\prime} \mathrm{W}$.

Moira Sound, branching inlet on east side of southern end of Prince of Wales Island. $55^{\circ} 05^{\prime} \mathrm{N} ., 132^{\circ} \mathrm{W}$.

Monterey Bay, bay in central part of California coast. $36^{\circ} 45^{\prime} \mathrm{N}$, $122^{\circ} \mathrm{W}$.

Naha Bay, bight on west side of Revillagigedo Island. $55^{\circ} 36^{\prime} \mathrm{N} ., 131^{\circ} 40^{\prime} \mathrm{W}$. River of same name.

New Morzhovoi, village on east side Isanotski Strait. $54^{\circ} 54^{\prime} \mathrm{N} ., 163^{\circ} 18^{\prime} \mathrm{W}$.

-New Red (Ayakulik) River, stream of the southwestern part of Kodiak Island. $57^{\circ} 11^{\prime}$ N., $154^{\circ} 30^{\prime} \mathrm{W}$.

Nichols Passage, water west of Annette Island, between Clarence Strait and Tongass Narrows.

Nicolai's barabara, an old barabara in Karluk River below the lake.

Nikolski, anchorage at Bering Island.

North Arm, northern arm of Moira Sound. $55^{\circ} 05^{\prime} \mathrm{N} ., 132^{\circ} 04^{\prime} \mathrm{W}$.

Nouiskay, lake and stream emptying into North Arm. $55^{\circ} 07^{\prime} \mathrm{N} ., 132^{\circ} 08^{\prime} \mathrm{W}$.

Oakland, city on San Francisco Bay, California.

Old Johnson, lake and stream emptying into Moira Sound from the south. $54^{\circ} 59^{\prime} \mathrm{N}$, $132^{\circ} 06^{\prime} \mathrm{W}$.

Osten Creck, main stream at head of Quadra Lake.

Otter Bay, small bight on west side of Pender Island. $48^{\circ} 48^{\prime} \mathrm{N} ., 123^{\circ} 18^{\prime} \mathrm{W}$.

Otter Point, projection of Vancouver Island into Juan de Fuca Strait. $48^{\circ} 21^{\prime}$ N., $123^{\circ}$ $49^{\prime} \mathrm{W}$.

()zette Lake, small lake in northwestern part of Washington. $48^{\circ} 05^{\prime} \mathrm{N} ., 124^{\circ} 40^{\prime} \mathrm{W}$.

Papermill Creck, small creek tributary to Tomales Bay, California, just above San Francisco. $38^{\circ} 10^{\prime} \mathrm{N}$., $122^{\circ} 50^{\prime} \mathrm{W}$.

Patching Lake, third fresh-water lake of the Naha system. See map.

Pavlof Harbor, small bight off Freshwater Bay, Chicagof Island, Southeast Alaska. $57^{\circ} 41^{\prime} \mathrm{N} ., 135^{\circ} 01^{\prime} \mathrm{W}$.

Payette River, tributary of the Snake River in western Idaho. $44^{\circ} 05^{\prime} \mathrm{N} ., 116^{\circ} 58^{\prime} \mathrm{W}$. Pender Island, small island north of Haro Strait. $48^{\circ} 47^{\prime} \mathrm{N} ., 123^{\circ} 16^{\prime} \mathrm{W}$.

Peninsula of Alaska, the long peninsula in the southwest of Alaska.

Point Adens, point of Prince of Wales Island north of Moira Sound. $55^{\circ} 07^{\prime} \mathrm{N}, 132^{\circ} \mathrm{W}$. Point Higgins, westernmost point of Revillagigedo Island. $55^{\circ} 27^{\prime} \mathrm{N} ., 131^{\circ} 50^{\prime} \mathrm{W}$.

Port Alexander, bay on east side Nigei Island, southern part of Queen Charlotte Sound. $50^{\circ} 50^{\prime} \mathrm{N} ., 127^{\circ} 40^{\prime} \mathrm{W}$.

Port Chester, bay indenting Annette Island on the west.

Prime of Wales Islemt. largest island of Alexander Archipedago, Southeast Alaska. $55^{\circ} 30^{\prime}$ N., $133^{\circ} \mathrm{W}$.

Puget Sound, large sound in northwestern Washington.

Quadra. (See Boca de Quadra.)

Quesnel Dam, a point on the Fraser River.

Revillagigedo Island, large island in the southern part of Alexander Archipelago. $55^{\circ} 30^{\prime} \mathrm{N} ., 131^{\circ} 30^{\prime} \mathrm{W}$.

Rivers Inlet, inlet of British Columbia, south end of Hecate Strait. $51^{\circ} 26^{\prime} \mathrm{N} ., 127^{\circ}$ $40^{\prime} \mathrm{W}$.

Roosevelt Lagoon, body of brackish water at mouth of the Naha River. See map.

$10731-07-8$ 
Sacramento, river and city of California.

Salmon River, tributary of Snake River, western Idaho, $45^{\circ} 50^{\prime} \mathrm{N}$, $116^{\circ} 50^{\prime} \mathrm{W}$.

San Pablo Bay, bay above San Francisco Bay. $38^{\circ} 05^{\prime}$ N., $122^{\circ} 23^{\prime}$ W.

Seton Lake, large lake of the Fraser system, British Columbia.

Shelikof Strait, waters between Kodiak Island and Alaska Peninsula.

Shelter Island, island at the head of Stephens Passage. $58^{\circ} 26^{\prime}$ N., $134^{\circ} 51^{\prime} \mathrm{W}$.

Sherringlam Point, projection of Vancouver Island into Strait of Juan de Fuca. $48^{\circ}$ $23^{\prime} \mathrm{N}, 123^{\circ} 55^{\prime} \mathrm{W}$.

Shumagin Islands, group south of Alaska Peninsula. $55^{\circ} \mathrm{N} ., 160^{\circ} \mathrm{W}$.

South Olga Stream, stream entering southern end of Olga Bay, southern part of Kodiak Island. $57^{\circ} 06^{\prime} \mathrm{N} ., 154^{\circ} 20^{\prime} \mathrm{W}$.

Spacious Bay, bay on east side of neck of Cleveland Peninsula. $55^{\circ} 51^{\prime} \mathrm{N} ., 131^{\circ} 46^{\prime} \mathrm{W}$.

Steelhead Creek, small creek falling into Naha Bay. See map.

Stikine River, large river from mainland in Southeast Alaska. $55^{\circ} 36^{\prime} \mathrm{N}$., $132^{\circ} 22^{\prime} \mathrm{WV}$.

Sucia Islands, small group just south of Georgia Strait. $48^{\circ} 46^{\prime} \mathrm{N}$., $122^{\circ} 54^{\prime} \mathrm{W}$.

Suisun Bay, bay above San Pablo Bay, receiving the Sacramento River. $38^{\circ} 07^{\prime} \mathrm{N}$., $122^{\circ} \mathrm{WV}$.

Sumner IIarbor (Bay), small bay northeast of town of Unalaska. $53^{\circ} 54^{\prime} \mathrm{N} ., 166^{\circ} 27^{\prime} \mathrm{W}$.

Susquehanna River, river in eastern Pennsylvania.

Tangas, inlet in the southern part of Annette Island. $53^{\circ} 01^{\prime} \mathrm{N} ., 131^{\circ} 32^{\prime} \mathrm{W}$.

Tehama, town on the Sacramento River, California, near head of steamboat navigation.

Thompson liver, tributary of the Fraser from the east, in British Columbia. $50^{\circ} 03^{\prime} \mathrm{N}$., $120^{\circ} 10^{\prime} \mathrm{W}$.

Thorne Bay, small inlet on east side of Prince of Wales Island, north of Kasaan Bay. $55^{\circ} 40^{\prime} \mathrm{N} ., 132^{\circ} 27^{\prime} \mathrm{W}$.

Tongass Narrow's, reach on southwest side of Revillagigedo Island connecting Behm Canal with Revillagigedo channel.

Truil Creek, small creek connecting Trout Ponds with Roosevelt Lagoon. See map.

Tribune Bay, small bight on south side of Hornby Island. $49^{\circ} 31^{\prime} \mathrm{N} ., 124^{\circ} 38^{\prime} \mathrm{W}$.

Trocadero, aquarium at Paris, France.

Trout Ponds, two small lakes near Loring. See map.

Ugaguk, large stream falling into Bristol Bay from the east. $58^{\circ} 14^{\prime} \mathrm{N} ., 157^{\circ} 34^{\prime} \mathrm{W}$.

Uganuk, bay in the north side of Kodiak Island. $57^{\circ} 54^{\prime} \mathrm{N} ., 153^{\circ} 30^{\prime} \mathrm{W}$.

Umnak Island, one of the Aleutian Islands, lying about $53^{\circ} 15^{\prime} \mathrm{N}, 168^{\circ} 15^{\prime} \mathrm{W}$.

Unalaska, town on the north side of Unalaska Island. $53^{\circ} 52^{\prime} \mathrm{N} ., 166^{\circ} 32^{\prime} \mathrm{W}$.

Union Bay, small bight off Baynes Sound, east side of Vancouver Island. $49^{\circ} 35^{\prime} \mathrm{N}$, $124^{\circ} 54^{\prime} \mathrm{W}$.

Unuk River, large river falling into Burroughs Bay at head of Revillagigedo Island. $56^{\circ} 03^{\prime} \mathrm{N} . .131^{\circ} 07^{\prime} \mathrm{W}$.

Uyak Bay, deep inlet on west side of Kodiak Island. $57^{\circ} 45^{\prime} \mathrm{N}, 153^{\circ} 53^{\prime} \mathrm{W}$.

Wallowa River, river in northeastem Oregon, tributary to the Grande Ronde. $46^{\circ} 03^{\prime}$ N., $40^{\circ} 03^{\prime} \mathrm{W}$.

Walmul Grove, village on the Sacramento River, between Sacramento and Suisun Bay.

IIanme River, tributary of Rivers Inlet, British Columbia.

Ward Cove, small bay on west side of Revillagigedo Island, between Point Higgins and Ketchikan.

Whidlyy Istand, large island in the northern part of Puget Sound. $48^{\circ} 09^{\prime} \mathrm{N}$., $122^{\circ} 34^{\prime} \mathrm{W}$. Hillemette River, large river of western Oregon, tributary to the Columbia.

Iitllow Creek, one of two main tributaries entering head of upper Karta Lake.

Wood River, large river emptying into Bristol Bay from the north. $59^{\circ} \mathrm{N}$., $158^{\circ} 23^{\prime} \mathrm{W}$.

Wrengell, town in north end of Wrangell Island. $56^{\circ} 28^{\prime} \mathrm{N} ., 132^{\circ} 22^{\prime} \mathrm{W}$.

Yes Bay, narrow inlet on east side of neck of Cleveland Peninsula opening into Behm

Canal. $55^{\circ} 53^{\prime} \mathrm{N} . .131^{\circ} 42^{\prime} \mathrm{W}$. Lake and stream of same name. Site of United States hatchery 


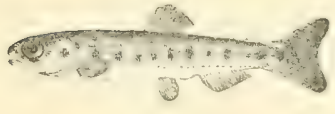

1. Sockeye fry.

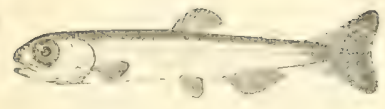

3. Humplatek salmon fry.

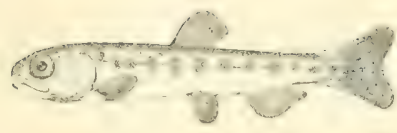

5. Dog satmon fry

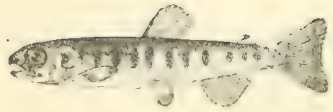

7. Trout fry:

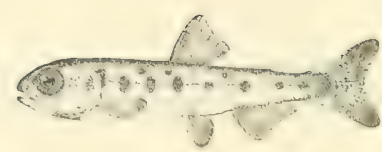

2. Sockeye no. 1 fingurling.

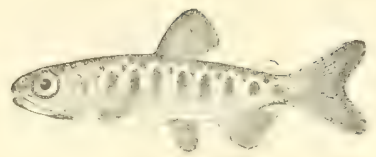

4. King salmon no, I fingerling.

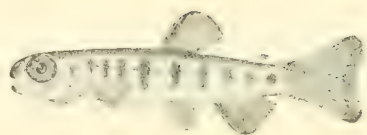

i. coho iry.

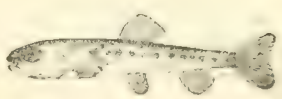

8. Chary iry.

MIGRATING YOUNG OF ALASKA SALMON AND TROUT.

(Natural size.) 



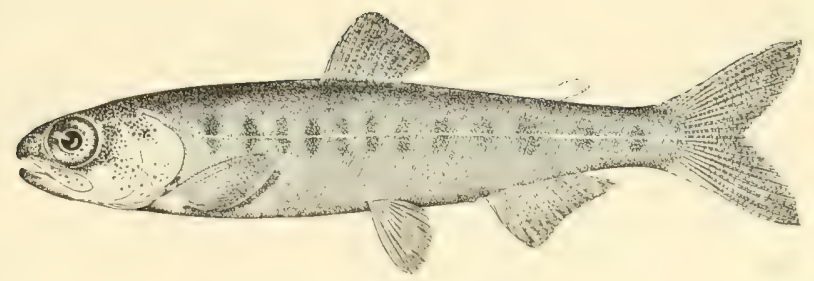

1. SOCKEYE FINGERLING.

(Niatural si\%.)

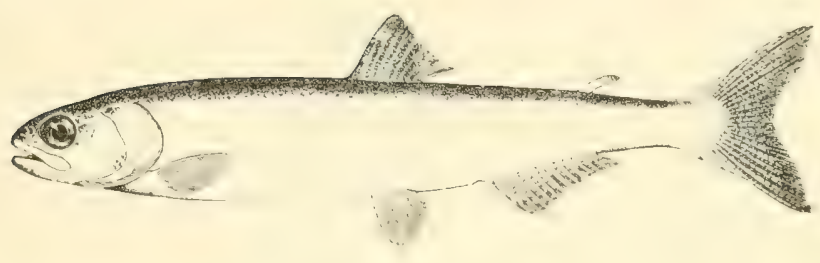

2. HUMPBACK SALMON FINGERLING.

| Nattural -ize.

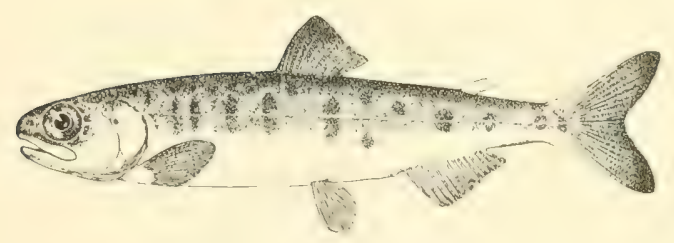

3. DOG SALMON FINGERLING.

I. Nutural size.

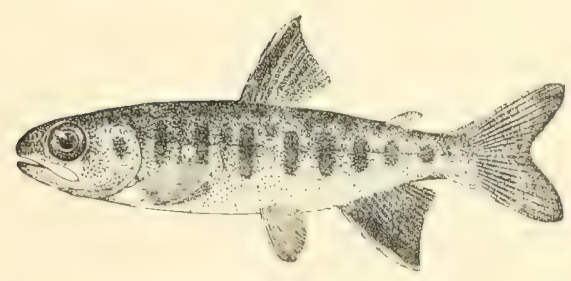

4. COHO NO. 2 FINGERLING.

(Nutural size.) 



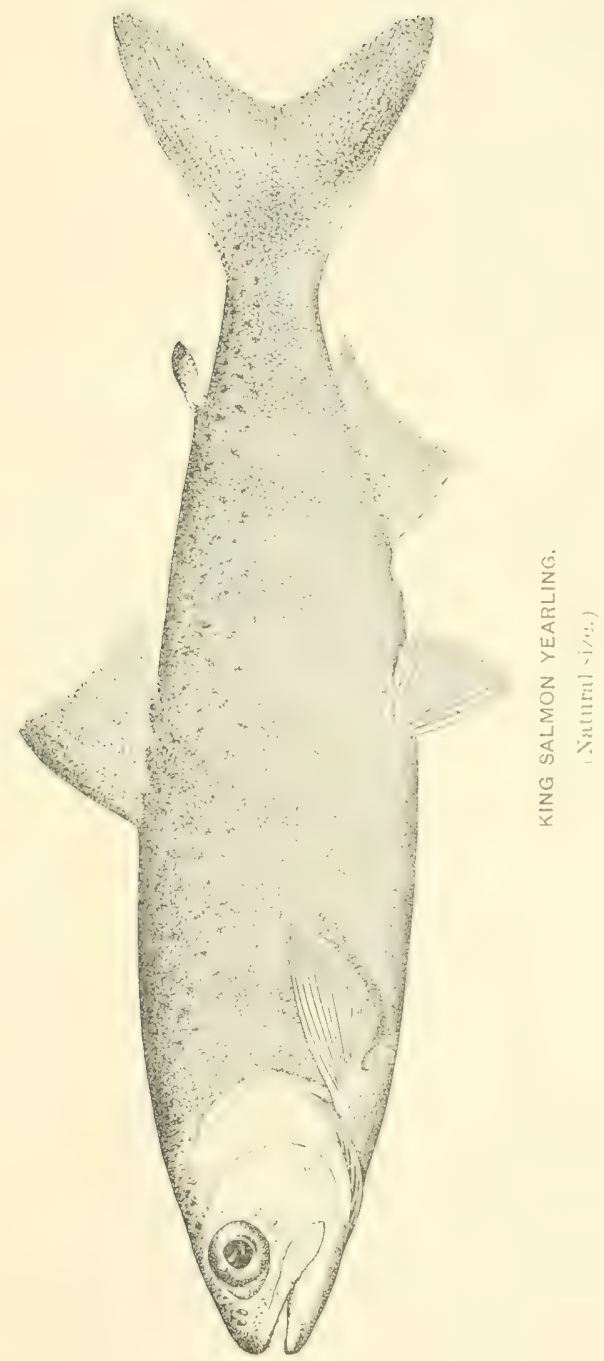





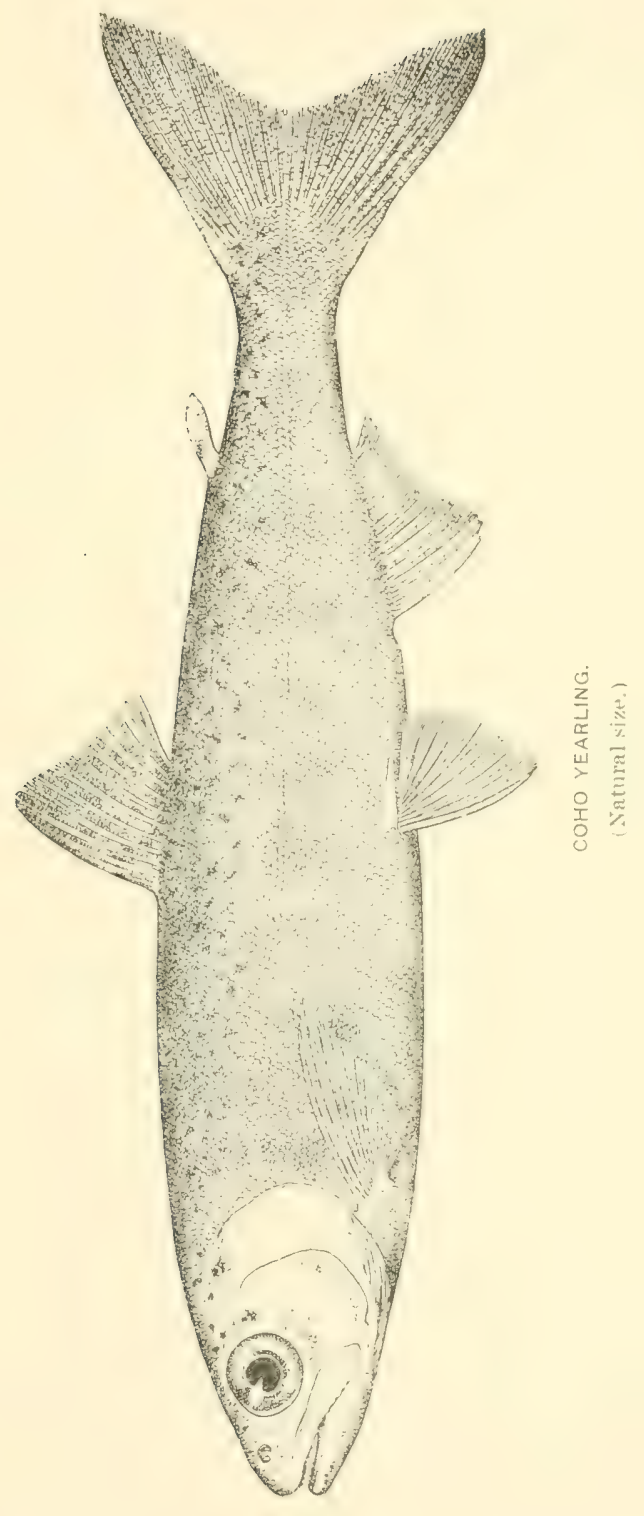





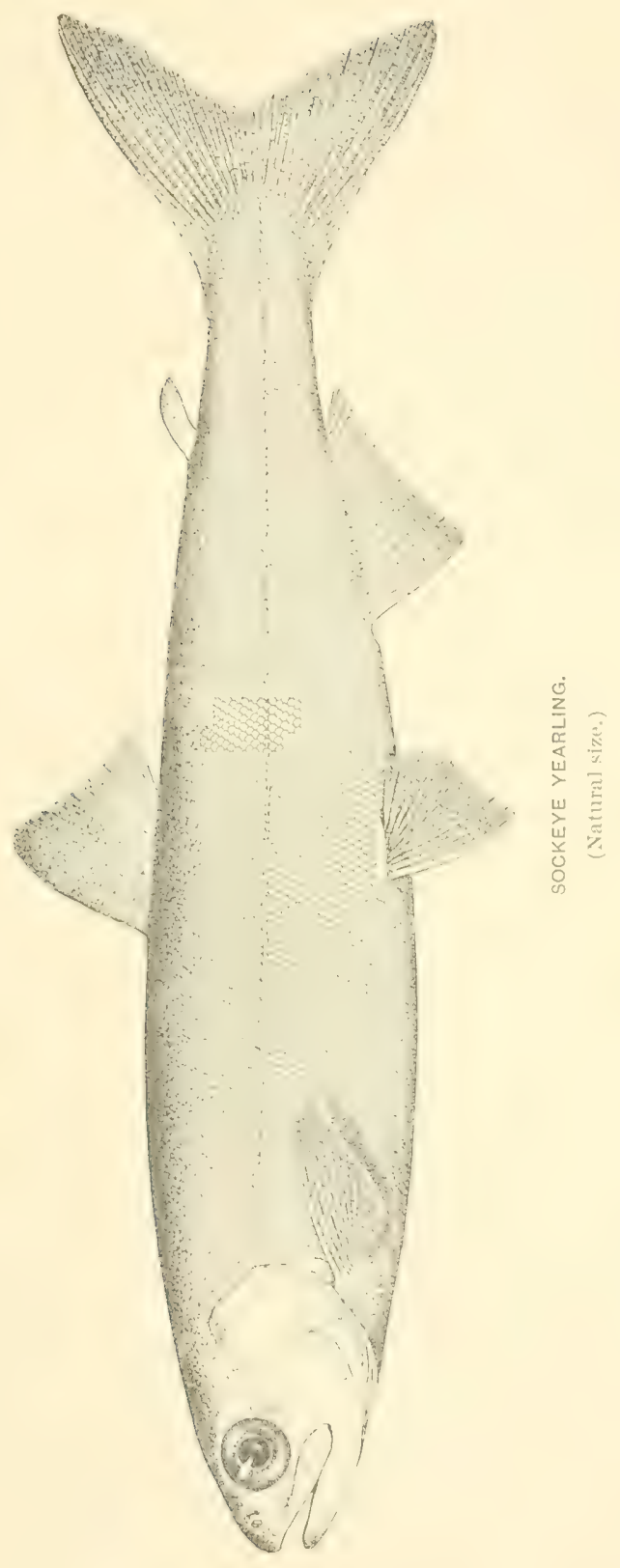


LEve D8 



